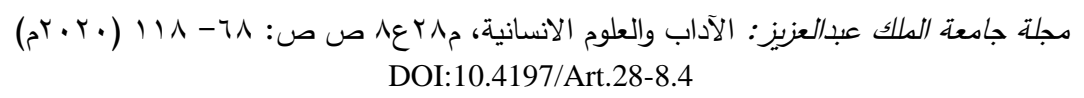

\title{
السماع في منظور العلماء
}

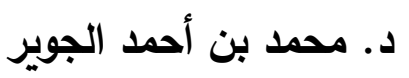 \\ جامعة دار العلوم
}

مستخلص. البحث يتتاول قضية من قضايا السلوك عند الصوفية، تمثلت فيما يُعرف عندهم بالسماع؛ باعتباره بحسب زعمهم

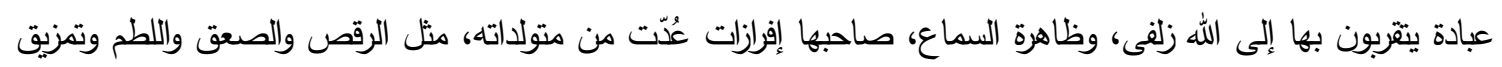

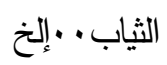
وقد نظر إليها علماء الأمة من (السلف والخلف) من المبتدات في اللين، مما توجّب عليهم إنكارها، والرد على أصحابها، وفق التقابق

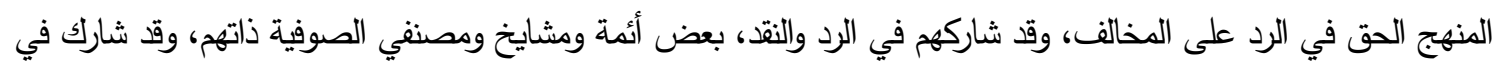
الرد والإنكار بعض الشعراء أيضًا والذي يلفت النظر ، أن هذه الردود والإنكارات كانت في كل عصر ومصر ؛ مما يؤكد وحدة المنهج في الدفاع عن العقيدة وتعرية خرافات المبتدعة.

على المحجـة البيضـاء ليلها كنهارهـا، لا يزينغ عنها إلال هالك.

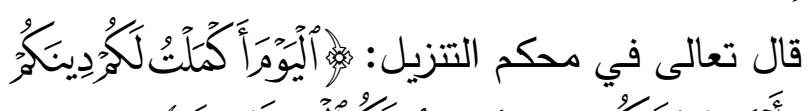

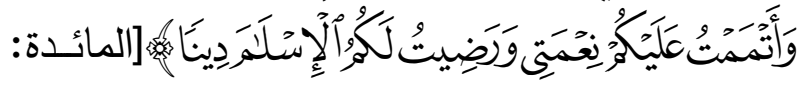

. [T وقال بال

\section{المقدمة}

فإن خير الحديث كتاب الله، وخير الهدى هدى محمد،

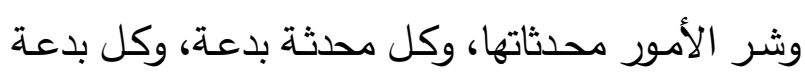
ضلالة، وكل ضلالة في النار .

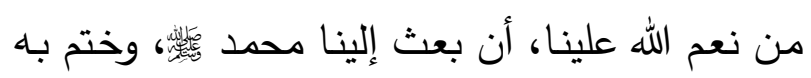
الرسـالة، وأقام بـه الحجـة، فحذّر من البدعـة، البن تاركنا 
بـارزين، تحفظ المراجـع وأمهـات الكتب، جهـودهم، وتتناقلها الأجيال بعدهم. ولعل أبـرز تلك الفـرق والطوائف، التي نالـت نقدًا وردودًا ظـاهرة هـي فرقـة (الصــوفية)، التـي تـدثرت بالزهد والعبـادة والنسـك في بـدء ظهورهـا في القرن الثاني الهجري تقريبًا، ولم تلبث أن تطورت مراحل نشأتها حتى آل الأمر بغلاتها إلى الاعتقاد بالحلول

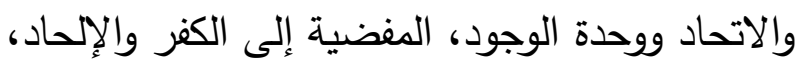
نتيجة تأثرها بالديانات الوثتية، والمذاهب الفلسفية. هـذه الفرقـة، تُعـدّ مـن الفـرق التـي ابتـدعت سـلوكيات ومعتقدات مصسادمة لثـعائر الدين المعروفة مـن الدين بالضـرورة، حتى أصـبحت مـن أشـهر الفـرق والطوائف المنتسبة للإسلام ابتداعًا؛ بل هي رأس المبتدعة. وفي هذا البحث، رأيـتُ أن أتتاول قضية مهمـة مـن قضـايا السـلوك عند الصــوفية، التي عـدَّوها عبـادة تقربهم إلى الله، تلك هي (دعوى السماع) وما يتولد منه من إفرازات، لم يثبت عليها دليل. والغاية من هذا البحث؛ كشف عوار وخفايا الصوفية في البدعة، التي سارت عبر القرون، ومازالت حتى هذا العصر ، تتنمامى بشكل بيّن، ولن يتأتى كشف

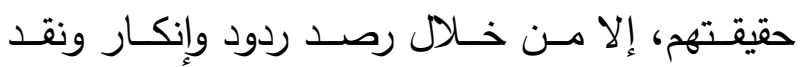
العلماء عليهم في كل عصر ومصر ، ولعلي في هذا البحث، أكتفي ببعض من هؤلاء العلماء، ممن تميز بغزارة علمه وقوة حجته. وقد رأتيتُ أن يكون عنوان هذا البحث: / السـماع في منظور العلماء وكان منهجي في إعداده قائمُ على الآتي:
فهو رد «" (') - (1) مـن أصـول الإسـلام، ومعتقد أهـل السـنة والجماعـة، ومنــاهجهم المعروفـة؛ تقريـر العقيـدة، والـرد علـى المخالف من أهل الأهواء والبدع.

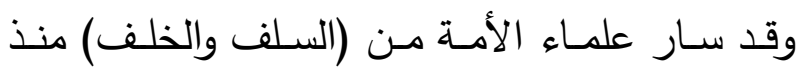
ظهور أهل الأهواء والبدع، بعد عهد الخلفاء الراشدين

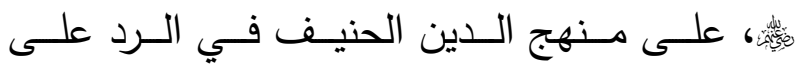
المخالفين بالإنكار ، والرد، والتحذير ، متبعين المنهج الصـحيح في ذلك على ضـوء مـنهج القرآن والسـنة المطهرة، من حيث الأصـول والمنـاهج، وإن تنوّعت أساليبهم، تبعًا للظروف في قرونهم. والمتأمـل في أحداث التاريخ الإسـلامي، بعد انتقال

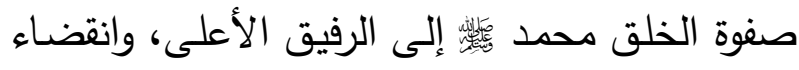
عهد الخلفاء الراشدين؛ يجد الخلافات والاضطرابات، فما تلبث أن تتطفئ فتتـة، إلا وتطل أخرى برأسـها، وما أن تتدثر طائفة أو فرقة، إلا وتبرز أخرى متدثرة

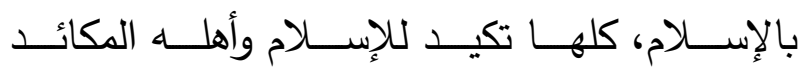
والمصائب. فعرففـت الجهميــة والجبريــة والمرجئـة، وعُـرف أهـل الكـلام مـن المعتزلــة والماتروديــة والآشــاعرة، كمــا عُرفت الباطنية من الإسماعيلية والدروز والنصيرية،

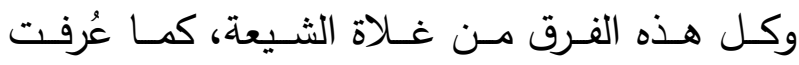
الصـوفية، وكـل هذه الفـرق والطوائفـ، تصـدّى لهـا

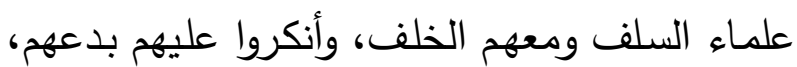
وسلوكياتهم، ومنـاهجهم، حتى صساروا بذلك أعلامًا،

( (1) صحيح البخاري، كتاب الصلح، باب إذا اصطلحو ا على صلح جور ،

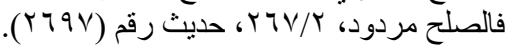


ويؤيد هذه النسبة السهروردي بقوله: "كان اختيارهم للبس الصوف لتركهم زينة الدنيا"(v). ثم يذكر أن هذا الاختيار ملأئم من حيث الاشتقاق اللغـوي، لأنـه يقـال "تصـوف إذا لبس الصـوف كمـا يقال تقدص إذا لبس القيصيص"(^). وممّن قـال بـذلك شـيخ الإســلام ابـن تيميـة بقولـه: "والنسبة في "الصوفية" إلى الصوف لأنه غالب لباس

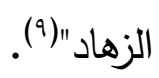
كمـا اختـار هــا القـول ابـن خلـدون بقولـه: قلـــ: والأظهر إن قيل بالاشتقاق أنه من الصوف، وهم في الغالب مختصّون بلبسـهـ لما كانوا عليـه من مخـالفة الناس في لبس فاخر الثياب إلى لبس "الصوف"(·').

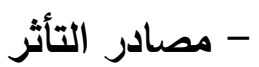

لقد أثبت المؤرخون، تأثر المتصوفة، بمصادر يهودية ونصرانية وهندية ويونانية ومجوسية وفارسية وقد يعود إلى عهود وثنية. يقول الدكتور زكي مبـارك: 》 الـرقص والتواجد في حلقات الأذكار لا يمكن رجعـه إلى أصـول إسـلامية صـحيحة؛ وإنمـا هـو أسـلوب قديم عرفـه النساس في

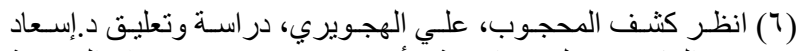

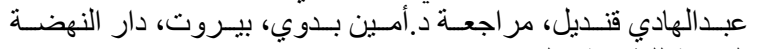

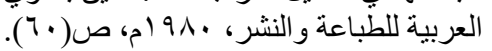

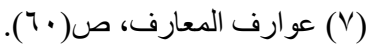

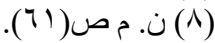

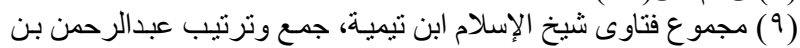

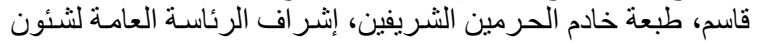

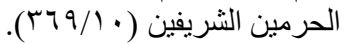

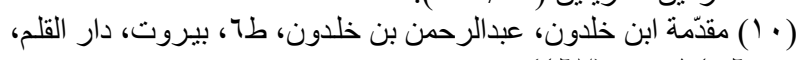
( )
1- عرض شباه الصـوفية، ثم بيـان موقف العلمـاء منها. ץ- أذكر تاريخ وفاة العالم لأول مرة يرد اسمه، وذلك في ثنايا البحث. ب- لا أترجم لأي من الأعلام، للحد من زيـادة حجم

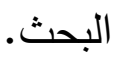
ع- أذكر اسم السورة ورقم الآية، بعد الآية مباشرة. - أدوّن معلومات المرجع لأول مرة في الغالب. 7- اكتقيــت بفهـرس للموضـوعات، وفهـرس آخـر للمصادر والمراجع. - - - التعريف الاصطلاحي للصوفية تعددت الأقوال حول التعريف الاصطلاحي للتصوف عند الصوفية وغيرهم، واختلفت الصوفية ذاتها ،حول هـا المعنـى، واختـلافهم هـذا،لا يقـلّ عـن اختلافهم الكبير حول أصله في اللغـة، إذ احتشدت بـه كتبهم

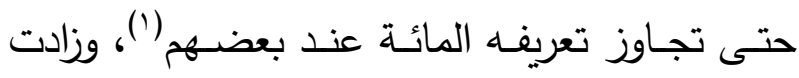
تعاريفه عن الألف عند البعض(ז)، بل قال بعضهم (r) أنها زهاء الألفين؛ لذا رأيت أن أكتفي بالقول الراجح في هذه التسمية وهو القول بالنسبة إلى (الصوف). وممّن نقـل هـذا عـن الصـوفية السـراج الطوسـي (؛)، والكلاباذي (0)، والهجويري (†).

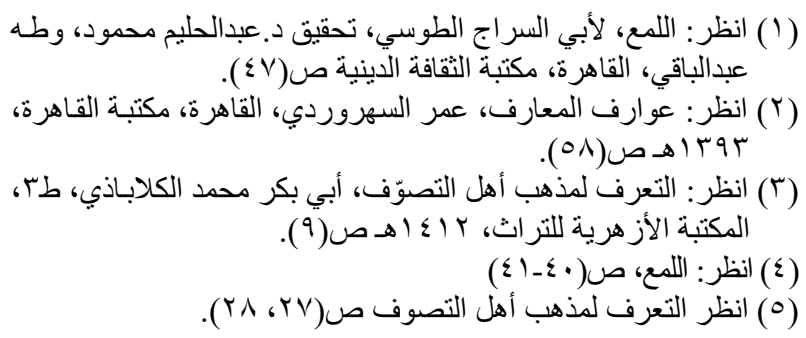


مختلفين في التصوّف أولهما الزهد، وهذا في نظره قريب

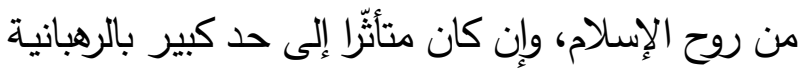
المسيحية. والثاني التصوّف بمعناه الحقيقي وما يتصل به من كلام في المعرفة والأحوال والأذواق، وهو متأثّر

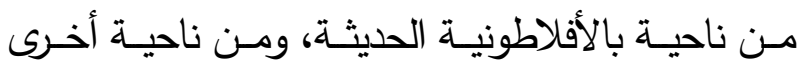
بالبوذية الهندية"(")، ويقول أحمد أمين: "ثم إن التصوّف لما كان مختلطاً مع الفقه في العصر الأوّل كان إسلاميا

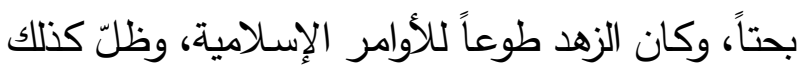

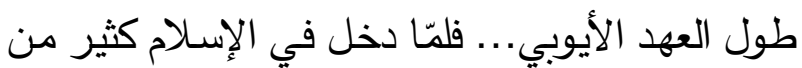

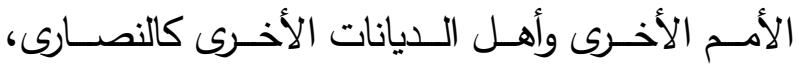
واليهـود، والفـــس، والهنـود، وانتشــرت الفلسـفة اليونانيـة

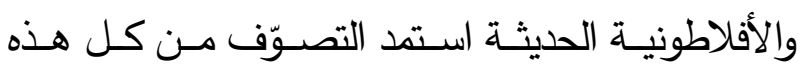
المنـابع، فلوّن عند بعض النـاس بالزراشتية الفارسية، وبالمذاهب الهندية، ولوّن عند بعض الناس بالنصرانية،

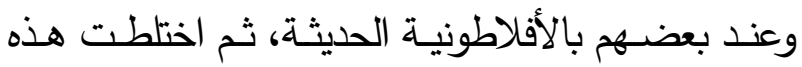
العناصر كلّها بعضها ببعض، وكانت نزعات مختلفة، وطرق مختلفة على مدى العصور" (؛).

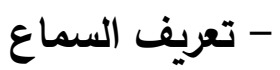
يُعدُّ السماع من الظواهر التي تلفت النظر عند أولئك

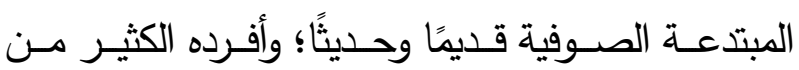
مشـايخهم ومـؤرخيهم ومصـنفيهم بمباحـث خاصـة في

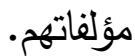

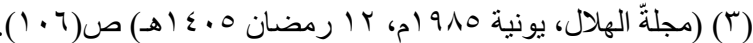

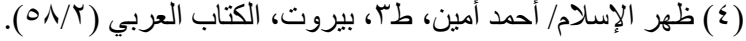

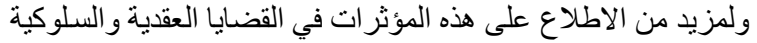

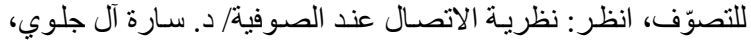

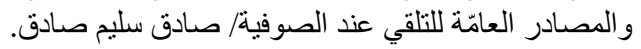

الديانات القديمة وكانت لـه صـور شـائعة في عهود الوثنية، فبعض الآلهة كانوا ظرفاء ويحبون لأتباعهم أن يتقربوا إليهم بالرقص والغناء والمجون «" (').

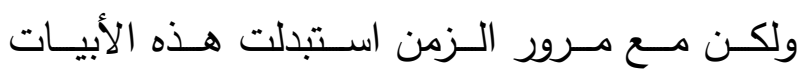

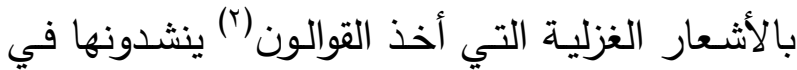

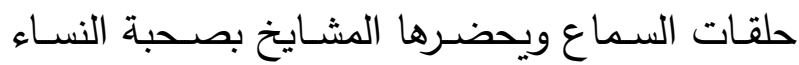
والمـردان حتى تشكَّل السماع بمفهومـهـ المقيد الذي لـي كان من إفرازاته الصياح والبكاء والصراخ والصعق لهقد والزعق والتصـفيق والـرقص وتمزيـق الثيـاب -كمـا

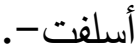

وفي تحقيق لمجلة الهلال المصرية " فإن التصوّف

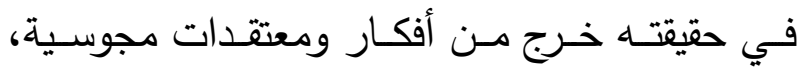
وبوذيـة، ومسيحية، ويهوديـة، ويونانيـة وهذه حقيقـة

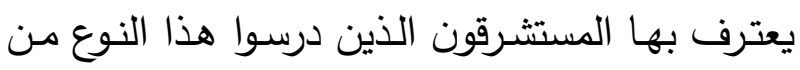
التصوّف الإسلامي، فهذا "فون كريمر" يقول: إن في التصوّف عنصرين مختلفين أولهما مسيحي رهباني والثاني هندي بوذي" والمستشرق ثولك، يرى أن التصوّف مـأخوذ من أصل بـون مجوسي، كما أن مؤسسي فرق الصسوفية الأوائل كانوا

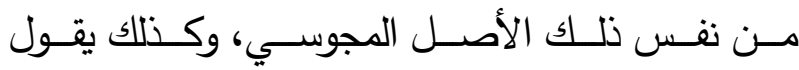

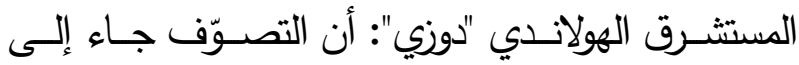
الصـوفية مـن فـارس، حيث كـان موجـودا قبـل البعثة المحمّدية. أمّا المستشرق "جولدزيهر" فقد فرّق بين تيارين

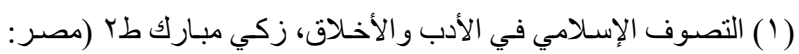

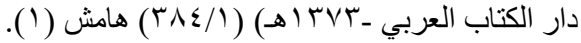
(r) القوَّال: هو المنشد في ذللك الزمان، المطرب و المغني في زمانتا هذا. 
التـي يتحـرك لهـا الطبـع بحسـب قبولـه: وهـو الذي

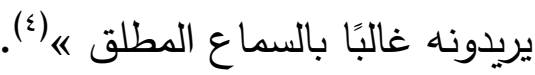
- آثار السماع على الصوفية: عند الاجتمـاع على الاستماع للمنشـ (القوَّال) وهو يلقي الأشـعار بالألحسان يتـأثر الحاضـرون وتصـدر مـنهم بعـض السـلوكيات تشـكل إفـرازه مـن إفـرازات السماع عندهم تكون متولدة تلقائيًا نتيجة غياب العقل -أشبه بالسـكارى-، ومسن هذه الإفرازات والمتولدات التي تبـدو ظـاهرة على هـؤلاء: البكـاء، والصـياح، تمزيق الثياب، اللط،، الرقص، التواجد، الزعق وغير ذلك. وهم يلتمسـون لهذه الأفعـال سـندًا مـن الكتاب والسنة والقياس.

\section{- الاحتجاج بالكتاب والسنة:} عندما يمارس الصوفية هذه السلوكيات؛ فهم يحاولون الاسـتـلال على ذلـك بالنصــوص الثـرعية، وهـي نصوص استخدموها في غير مـا تدل عليه، أو لا تصـح أصسلاً نسـبتها إلـى الثـارع، وقـد وجـدت وللأسف الثـديد - قبـولاً لدى الرعـاع مـن الصـوفية،

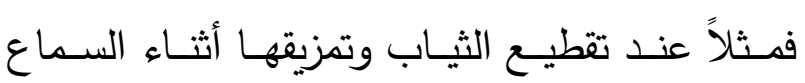

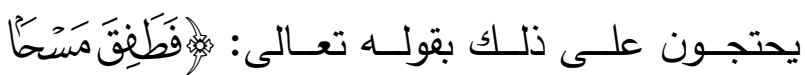

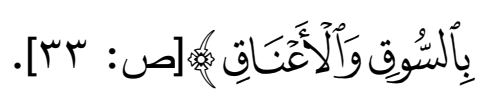

وأثتـاء تواجدهم عند السـماع يحتجـون بقصـة رووهـا

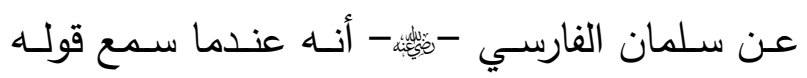

( ) الفتوحسات المكيـة لابـن عربـي، القـاهرة، دار الكتب العربيـة الكبرى،

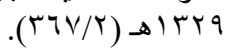

فلا يخلو مصنَّف من مصنفات القوم من ذكره والتشفي بـه، فكثرت فيـه أقوال مشـايخ الصـوفية وأوليائهم والدعوة إليـه والاعتقــاد بإباحيتهـ، كالسـراج الطوسـي في اللهـع، والقشيري في رسالته، والسهروردي في عوارف المعارف، حيـث عقــ أربعـة أبـواب في السـماع، والغزالـي في الإحيـاء، ومحمد بـن طـاهر في صـفة أهـل التصـوف وغيرها. فيا ترى ما المقصود بالسماع عند الصوفية؟ السماع لغة: قال ابن منظور : هو الغنـاء، وقيل الذكر المسموع الحسن الجميل، وكل ما تلذذت به الأذن من صوت حسن سماع|(') - السماع في الاصطلاح الصوفي:

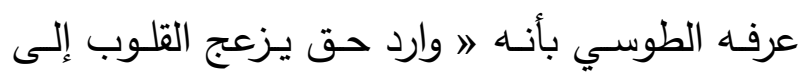
الحق فمن أصنى إليه بحق تحقق، ومن أصنى إليه بنفس تزندق «") وقـال عنـه القشـيري بأنـه: 》 بـروق تلمـع ثم تخمـد،

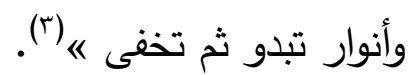

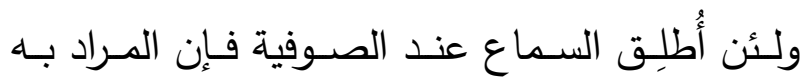
عندهم السماع المقيد بالنغم لا مطلق السماع، يقول ابن عربي: \ا السماع المقيّد بالنغمات المستحسنات

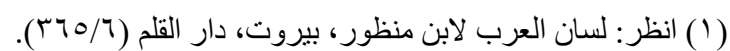

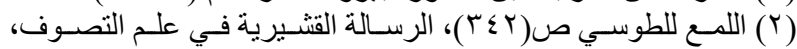

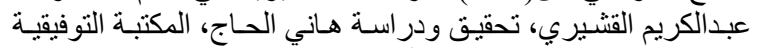

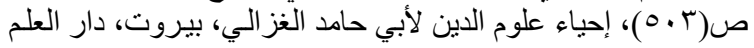
. ( $(Y 9 Y / r)$

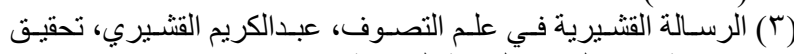

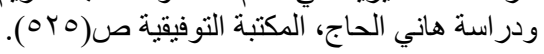




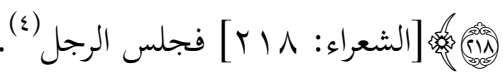

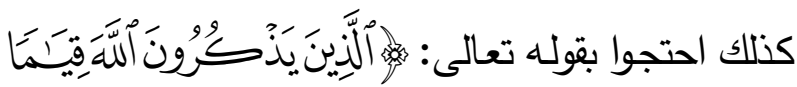

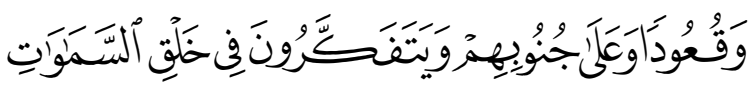

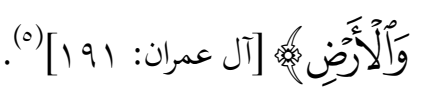

واحتجـوا على جـواز الطـرب بقولـه تعـالى : أرضخُ

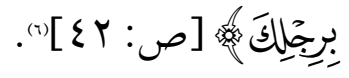

أيضًَــا احـتج الصــوفية عــى جـواز هـــه الإفــرازات

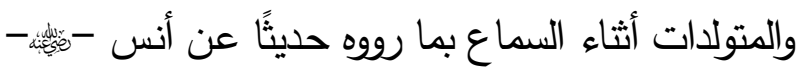

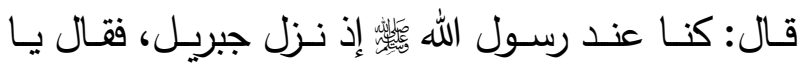
رسـول الله: إن فقراء أمتك يـذخلون الجنـة قبـل الأغنيـاء

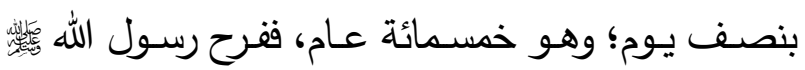
فقال: هل منكم من ينشدنا؟ فقال بدوي: نعم يا رسول الله، فقال: هات؛ فأنشد أعرابي:

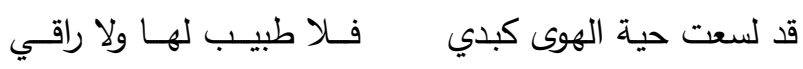
إلا الحبيب الذي شغفت به فعنـــده رقيتــي وتريــاقي

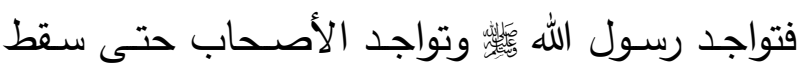
رداؤه عن منكبه، فلما فرغوا آوى كل واحد منهم إلى مكانه، قال معاويـة بن أبي سفيان: مـا أحسن لعبكم يا رسول الله، فقال: مه يا معاوية، ليس بكريم من لم يهتز عند سماع الحبيب، ثم قسم رداء رسول الله (ع) ص(انظر : الرسالة القشيرية ص(9).

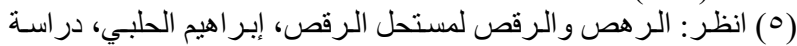

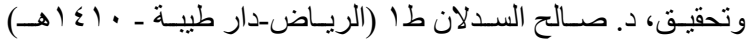
ص(90).

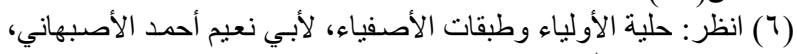

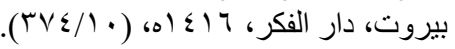

تعـالى : بـ] صساح صيحة، ووضـع يده على رأسـه ثم خرج هاربًا ثلاثثة أيام (') ومن سلوكياتهم عند السماع الزعق والصياح والبكاء، فقد روي عن الشبلي حكاية أنه كان يصلي خلف إمام

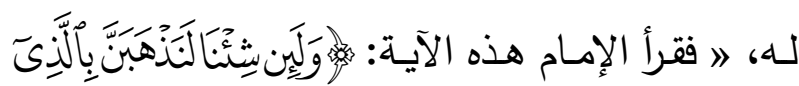

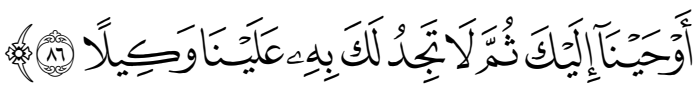

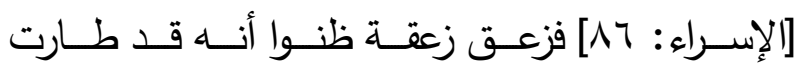

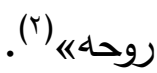

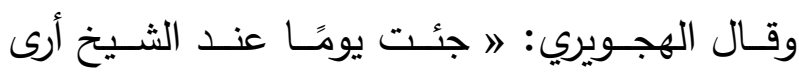
العبـاس الثـقاني وكـان يقـرأ:

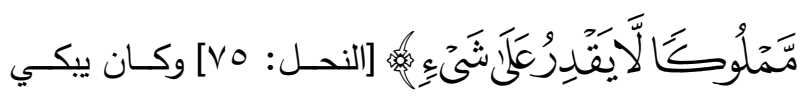
ويصرخ حتى ظننت انه قد فارق الحياة «(). وحكي عن ذي النون المصري أنه لما دخل بغداد فذخل عليه جماعة معهم قوَّال (منشد)، فاستأذنوا أن يقول شينًا

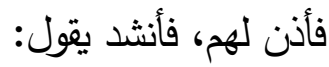

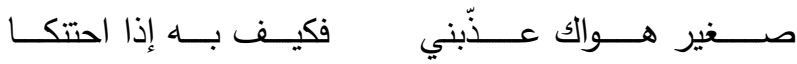
إذا ضــحك الحلـسَّ بكىى

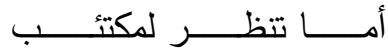

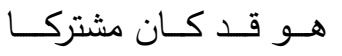

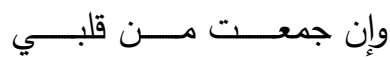
فطـاب قلبـه وقـام وتواجد وستط على جبهتـه والـدم يقطر من جبينه ولا يقع على الأرض، ثم قام واحد

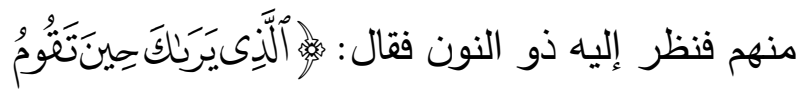

(1) (1) (1) (1) ( ) ).

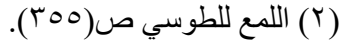

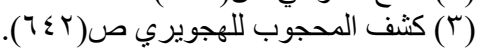


أيضًَــا يقـيس الســهروردي الســماع علــى الغيـــ (المطر)، فيقول 》 مثل السماع مثل الغيث، إذا وقع على الأرض تصبح مخضـرة، كذلك القلوب الزكيـة يظهر مكنون فوائدها عند السماع «("). والصـوفية عندما تبدوا عليهم هذه الآثار التي سبق وأن بيناها دن الصياح والبكاء والزعق وتمزيق الثياب والتواجد وغيرها تحضرهم بذلك الشياطين وتشاركهم؛ بل تأزهم على ذلك أزًا، وهم يقرون بذلك. يقول الهجويري: \ قال سمعت أبا العباس الثقاني يقول: كنت يومًا جالسًا في مجلس سماع فرأيت كثيرًا من الشياطين عراة الأجسام، يرقصون بين الجماعة ينفثون عليهم لكي يزيدوا من حماسهم «("). - السماع قربة عند الصوفية: بلغ السماع عند الصوفية درجة قدسية رفيعة، تتجلى تلك عندما عدّوا مجالس السماع من مجالس نزول الرحمـة، واعتقدوا ذلك السماع من الدين المنزل من رب العالمين، وبالتالي فهو عبادة من العبادات التي تقربهم إلى اللهزلفى، وأي عبادة!!. فهذا الجنيـد المسـمى عنـدهم (سـيد الطائفـة) يقول: " تــزل الرحمـة علـى الفقـراء -الصــوفية- في ثـلاث مواطن، عند السماع فإنهم لا يسمعون إلا عن حق ولا يقولون إلا عن وجد وعند أكل الطعام فإنهم لا يأكلون

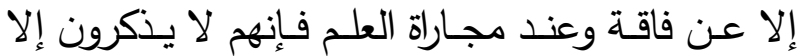

(0) آداب المريدين للسهروردي، تحقيق فهيم شلتوت، القاهرة، دار الوطن

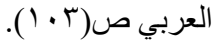

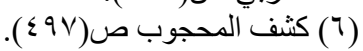

على من حضر بأربعمائة قطعة «" ('). كمـا استـل الصـوفية أيضًا على جـاز هذا السـاع بما روي عن عائشـة -رضي الله عنها- قالت: دخل عليَّ أبوبكر الصـديق وعندي جاريتان مـن جواري الأنصار ، تغنيان بما تقاولت به الأنصار يوم بعاث، قالــات : وليســا بمغنيتـين، فقـال أبـوبكر : أمزمــار الثيطان في بيت رسول الله بَلّئ، وذلك يوم عيد، فقال

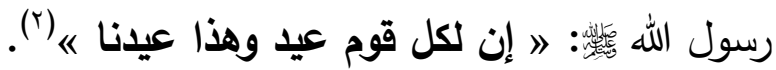
- الاحتجاج بالقياس: لـم يكتف هـؤلاء القـوم بالاحتجـاج بالكتـاب والسـنة، ولكنهم أيضًا جعلوا من القياس حجة لهم، فقد احتج بذلك القشيري على إباحة الغناء بقوله: 》 إن الطفل يسكن إلى الصـوت الطيـب، والجمـل يقاسـي تعـب السير ، ومشقة الحمولة فيهون عليه بالحداء «(ז". وقـد روى الهجـويري أن بعـض ملـوك العجـم مـات

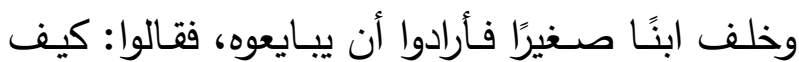
نصل إلى عقله وذكائه، فتوافقوا على أن يأتوا بقوَّال (منشــد) فـإن حسـن الإصــاء علمـوا كياسـته فلمـا أســعوه القهوَّال ضـحك الرضـيع، فقبّلـوا الأرض بـين يديا وبايعوه!!(؛).

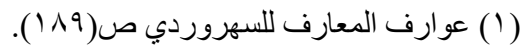

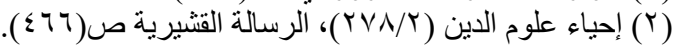

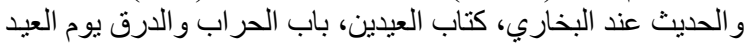
(Y/Y)

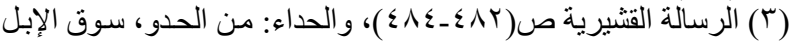

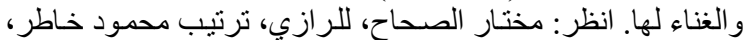

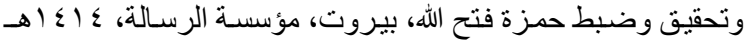
ص(

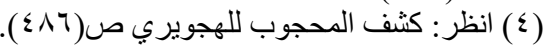




$$
\text { وإذا سمع شعرًا قامت قيامته « (₹). }
$$

وهذا أبوحامد الغزالي يقول: 》 فاعلم أن الغناء أشد

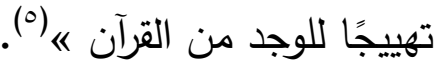

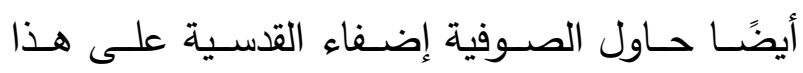
السماع من خلال حكايات وروايات ظاهرها الكذب، أبهاء منها ما روي عن ممشاد الدينوري أنهـ قال: " رأيت

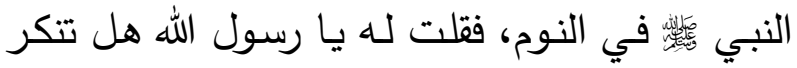
من هذا السماع شينًا؟ فقال : ما أنكر منه شينًا، ولكن قل لهم يفتتحون قبلهـ بقراءة القرآن ويختمون بعده بالقرآن «" (־). ومما يدل على كون السماع عندهم من الدين، أن بان أبا الفضل بن طاهر المقدسي الصوفي (ت V.0. مــ

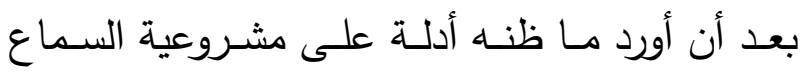

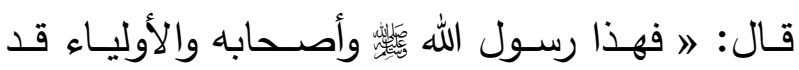
اجتمعوا للسماع وتواجدوا ورقصوا في اليقظة والنوم، فكيف ينكره أحـد اليـوم ومـا كـان كذلك فهـو ديـن

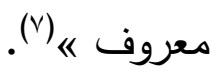
ولا يرون بأسًا في حضور الملاهي لسماع الأغاني

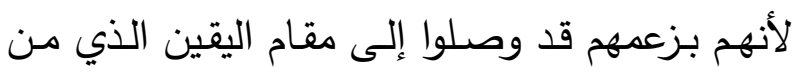

وصله سقطت عنه التكاليف الثرعية! فقـــ نقـل عـن رجـل مـن المتصـوفة، كـان يحضـر

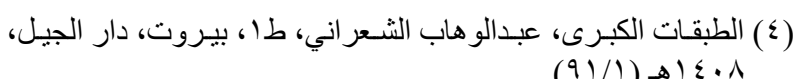

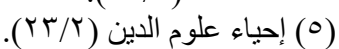

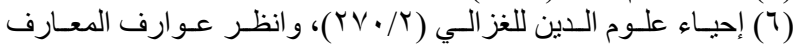

$$
\begin{aligned}
& \text { ص(1) (1) (1). (1) (1) }
\end{aligned}
$$

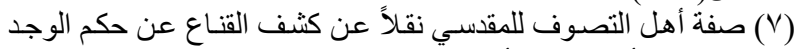

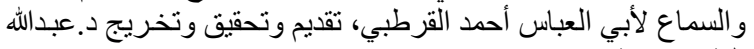

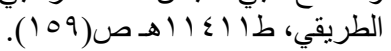

صفة الأولياء «(') والعجب كل العجب أن جعل الصوفية منزلة السماع تفوق منزلـة القرآن -والعياذ بـالله-؛ بـل أكبر تأثيرًا على قلوبهم منه. يبدو هذا السلوك جليًا في هذه الروايـة فقد روي أن

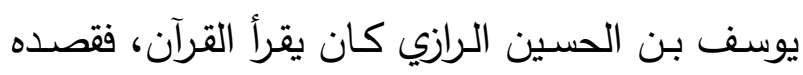

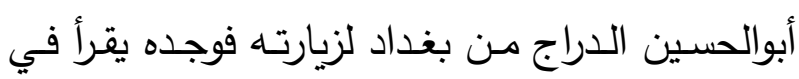
المصحف، فلما أنثد أبوالحسن: رأيتك تبني دائمًا في قطيعتي ولو كنت ذا حزم لهذمت ما تبني

كأني بكم والليث أفضل قولكم ألا ليتنا كنا إذ

$$
\text { الليث لا يغني }
$$

فأطبق يوسف بن الحسين المصحف، ولم يزل يبكي، لإني حتى ابتلت لحيته وابتل ثوبه، حتى رحمه أبوالحسين ين ين ليكين

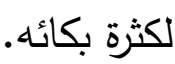

ثم قال يوسف بن الحسين يا بني تلوم أهل الري(؟):

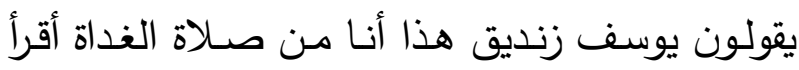
المصحف، ولم تقطر مـن عيني قطرة، وقد قامـ القيامة عليَّ بهذين البيتين ها"( ال. وتأكيدًا لهذه الرواية، فقد وصفه الشعراني في طبقاته لينه

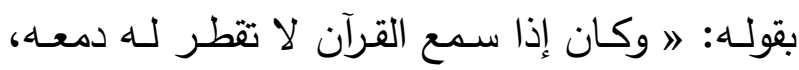

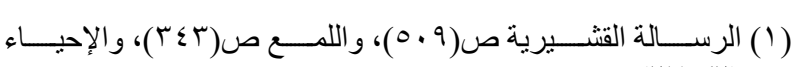

$$
\begin{aligned}
& \text { (rV./r) }
\end{aligned}
$$

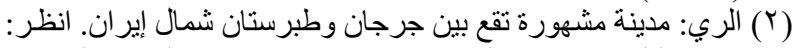

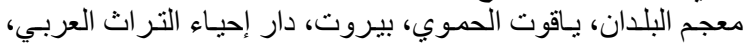

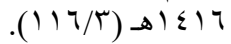

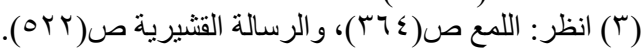


جميـع مـا فـي لا إلـهـه إلا الله مـن العقائدـ والعلـوم والآداب والحقائق.... «"). والثـاهد من هذا أن الصوفية تمارس الرقص والوجد

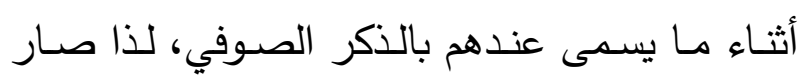
الذكر قرينًا لللماع عندهم. ومما ينبغي الإثارة إليه أن باب الأذكار هو الباب

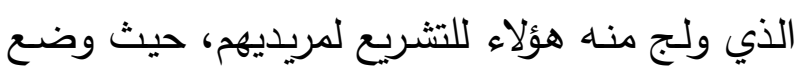
كل شيخ طريقة أذكارًا مخصوصة وكان لان لاند لابد لكل شيخ أن يضفي على ذكره هالة من التقديس فمنهم

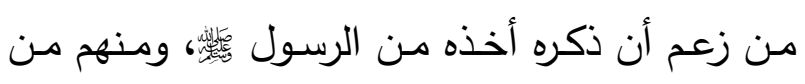

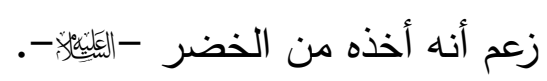
وهذه الأذكار قد تحوي كلمات غير مفهومه، وكل الخل يدعي الوصل بليلى!!.

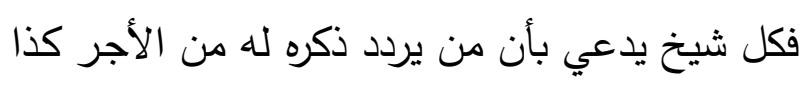

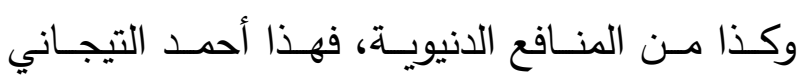

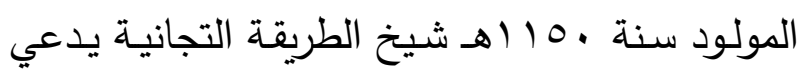

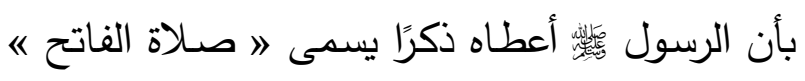

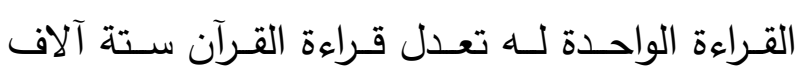
مرة)

- النظر إلى وجه الأمرد من إفرازات السماع:

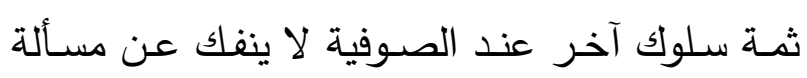

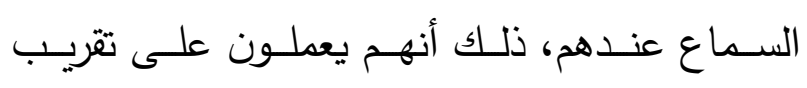
الثباب الهـرد ويجـوزون النظر إلى وجوهم أثنـاء

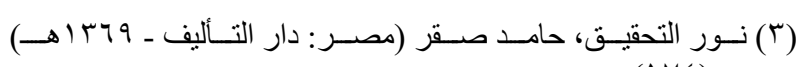
ص( ) ( I

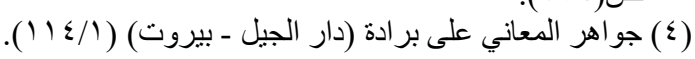

الملاهي، ويعمل عمل أهل البدع ويقول: هذا لا

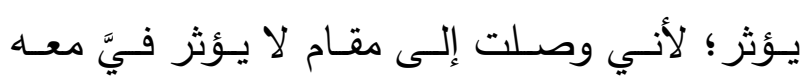
الاختلاف (') - الرقص من متولدات السماع: - الرقاع لدى المتصوفة عبادة، يمارسونها على غير وجهها الصحيح، هي عبادة (الذكر).

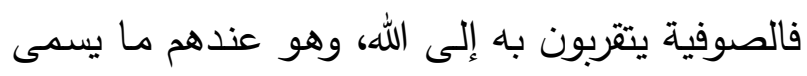
بالذكر الصوفي، يفردون الله بالذكر ، ويذكرون الله والنبي

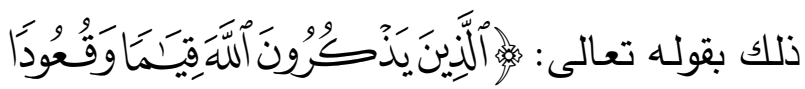

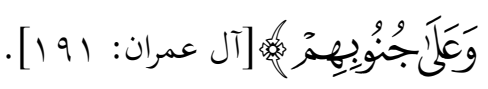
فمن بدعهم في الذكر ، ما يجري على ألسنتهم من النه

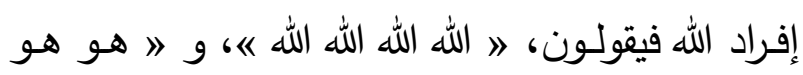

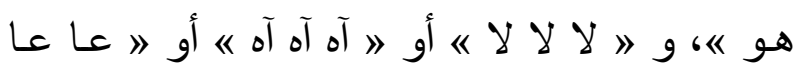

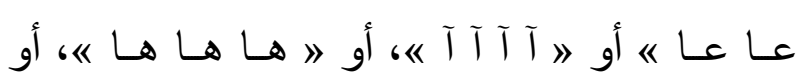

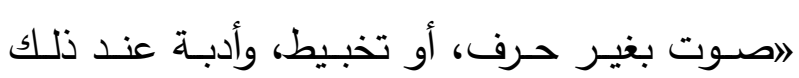
التسليم للوارد (r). ويقول أبوالعباس المرسي: " ليكن ذكرك: الله الله،

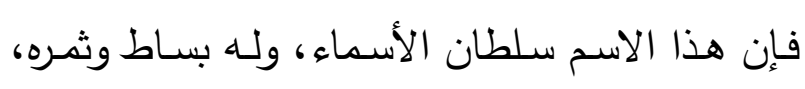
فبساطه العلم، وثمرته النور ، وليس النور مقصودًا لذاته، بل لما نفع به الكثف والعيان، فينبغي الإكثار

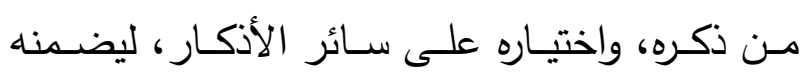

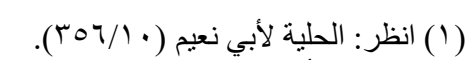

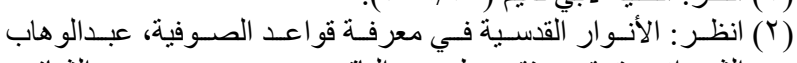

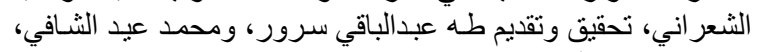

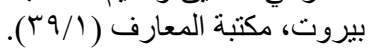


ما سبق هو المفهوم السلوكي للسماع عند الصوفية وآثاره عليهم، ومنزلته عندهم، وذلك من واقع أقوال مشايخهم، التي ساقها أئمتهم ومصنفوهم. وبعد هذا العـرض لهـذه الـدعاوى الصـوفية، نسـوق كلام علماء الأمة حولها؛ لنقف على موقفهم من هذه الممارسات والسلوكيات، ليتبين الحق من الباطل. - السماع في منظور العلماء سبق وأن أشرثُ إلى أن دعاوى الصوفية بمجملها، لم تكن محصورة في قرن دون آخر؛ بل أنها وجدت مـع التصوف والصوفية، منذ تاريخ نشأته، وسارت عبر

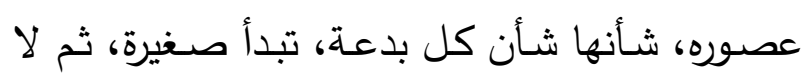
تلبث أن تكبر مع مرور الزمن. لقد أنكر العلماء في كافة القرون، منذ ظهرت مرون الصوفية وحتى اليوم على المتصوفة بدعهم ومخالفاتهم للعقيدة والشريعة والمنهج والسلوك، وبينوا ما يترتب عليها من مخالفات شرعية، وفندوا ما أحدثوه من بدع منكرة في هذا الشأن، ومن خلال ذلك أصلوا حكم الإسلام في السماع، وما يصحبه من آفات ومخالفات، تجسدت بإفرازاته، ومتولداته

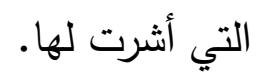
لا شــك ولا ريــب أن هــذه الــدعوى والممارســات

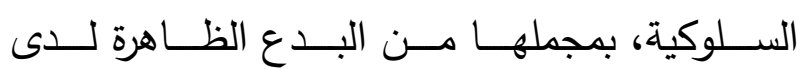
المتصوفة، والتي لم يزل علماء الأمسة، في كل قرن، وحتى اليـوم، يُفندونها بدعـة، بدعـة، ويردونهـا، بـل ينكرون على من يعتقد بها، ويمارسـها، سندهم في ذلك، قال الله وقال رسوله تئس
اجتمـاعهم للسـماع، بـل إن البعض مـنهم قد يمارس بعض السلوكيات المشينة والشـاذة مـع هؤلاء المرد، بحجة النظر والاعتبار لزيادة الإيمان، هذا ما يتضح

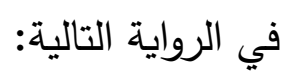
فقــ ذكـر الثـعراني في طبقاتـهـ في ترجمــة علـي أبوخوذة: 》 أنه إذا رأى امرأة أو أمردًا راوده عن نفسه

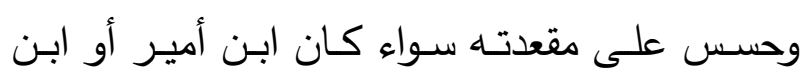

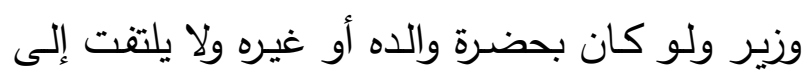

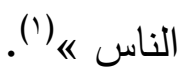
وكان علي الحريري أكثر المتصوفة تهتكًا في معاشرة الأحداث 》 فكان من وقع نظره عليهـ من الأحداث وأولاد الجند والأمراء وغيرهم يحسن ظنـه فيه، ويميل إليه، ولا يعود ينتفع بـه أهله، بل يلازمها ويقيم عنده، اعتقادًا فيه وميلاً إليه «(؟). وقد أبـاح محمد بـن طـاهر المعـروف بـابن القيسراني، للصوفية النظر إلى وجوه المرد وظلك بتصنيفه رسالة في إباحة السماع والنظر إلى المرد("). والثـعراني يؤكد هذا السـلوك عند الصـوفيه، عندما أورد خبر الصـالح محمد بن عراقي، الذي كان لا يمكِن ابنهـ عليًا من الخروج إلى السوق، حين كان أمرد، إلا أن يُرَرقع خوفًا عليه من السوء والفتنة(؟).

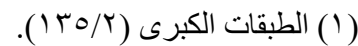

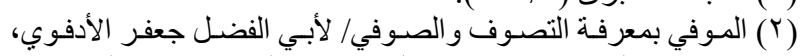

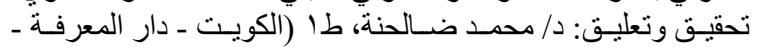

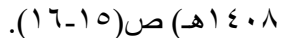

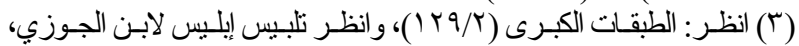

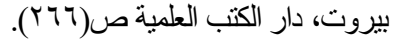

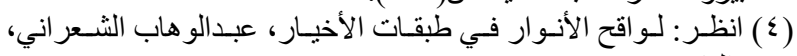

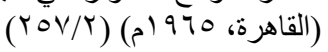


عبدالرحمن بن رجب (ت 90 Vه) ('). ^- الـرهص والــوقص لمسـتحل الـرقص، لإبـراهيم

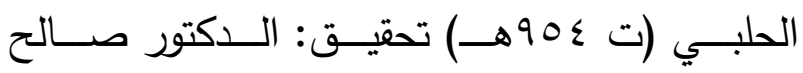
السدلان.

9- كف الرعاع عن محرمات اللهو والسماع، لابن حجر الهيتمي (ت ع \هـ). هذا وقد دلَّ الكتاب والسنة على تحريم الغناء.

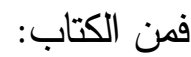

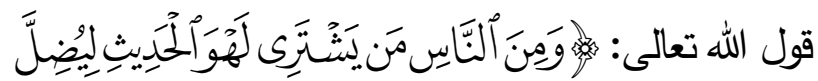

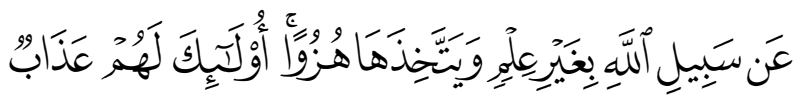

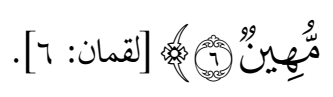

قـال ابن مسـعود، وابـن عبّاس، ومجاهد، وعكرمـة: لهـو الحـديث هـو الغنـاء، ذكر ذلك البغـوي وقـال:

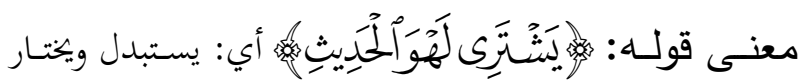
الغناء والمزامير والمعازف على القرآن(r).

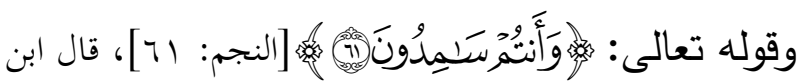
عبّاس: هو الغناء (r).

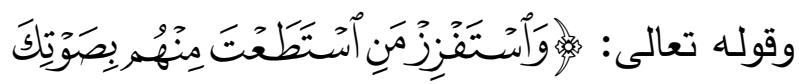

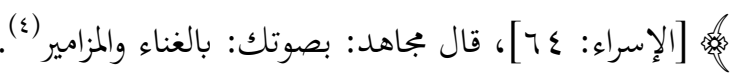

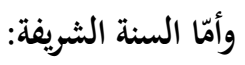

\footnotetext{
(1) لمزيد الاطلاع على المؤلفات في مسـألة السماع: انظر : مقدمـة كتاب المقاب

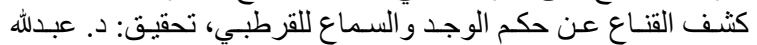
الطريقي.

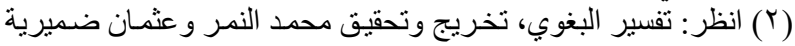

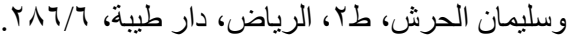

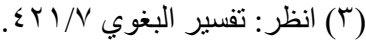

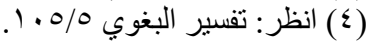

وقبل أن نقف على تلك الجهود، التي كُرّست، لتفنيد هذه البدـع الظـاهرة، وإنكارهـا والرد على أصـابها، يلزمنا معرفة الحكم الشرعي إزاءها ابتداءً. - حكم السماع الصوفي: بذل علماءُ الأمة، جهدهم وأفنوا أعمارهم، بالرد على المبتدعات والمحدثات في الدين، وما أن أطلَّت بدعة السماع عند الصوفية برأسها؛ إلا وتصدى لها هؤلاء العلمـاء الأجـلاء في كل عصـر ومصـر، بتفنيـدها والإنكار على أصحابها أشد الإنكار، وكان لأسلوب الرد، بالتأليف النصيب الأوفى، فكثرت المؤلفات في مسألة السماع؛ لاسيما التي تتكرهـا، وتعتبرها بدعـة من أشهر البدع عند الصوفية. وهذه بعضًا منها مطبوعًا: ا- الـرد على مـن يحـب الســاع للقاضـي طـاهر

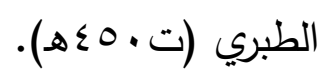
ץ- كتاب رسـالة في تحريم الجبن الرومسي وتحريم الغناء والسماع لأبي بكر محمد بن الوليد الطرطوشي (ت • (ت ) r- فتاوى في ذم الشبابة والرقص والسـماع، لموفق الدين أبي محمد بن قدامة (ت . ب Tهـ).

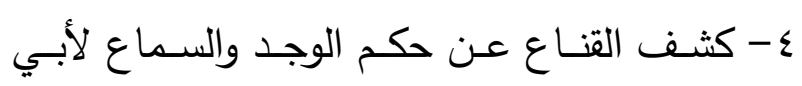
العباس أحمد القرطبي (ت 707 هـ).

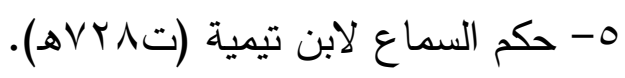

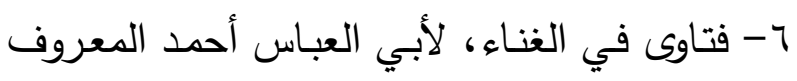
بابن قاضي الجبل (ت أO Vه). V- نزهـة الأسـماع في مسـألة السـماع، لأبـي الفرج 
ثم بيّن ابن قدامة أن هذا التغبير هو السماع، وهو

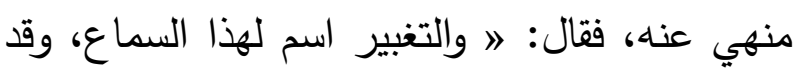
كرهه الأئمة كما ترى، ولم ينضم إليه هذه المكروهات

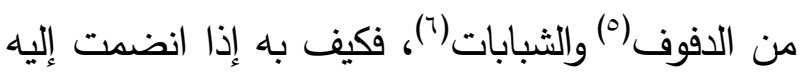
واتخذوه دينا؟ فما أشبههم بالذين عابهم الله تعالى بقوله:

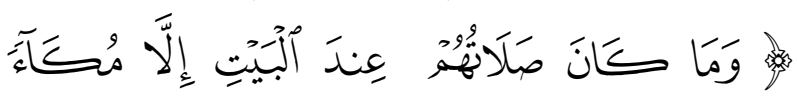

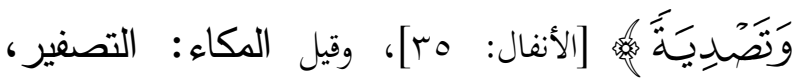
والتصدية: التصفيق، وقال الله سبحانه لنبيه

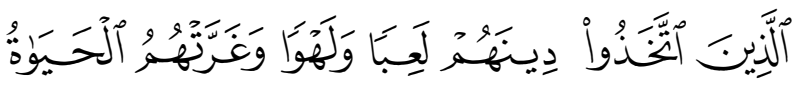

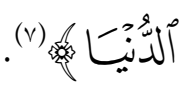

وقـال ابـن قدامـهـ رحمــهـ الله: 》 مــن اتخـــ الغنــاء صناعة، يؤتى له ويأتي له، أو اتخذ غلاما أو جارية

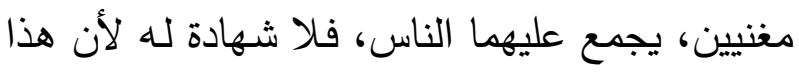

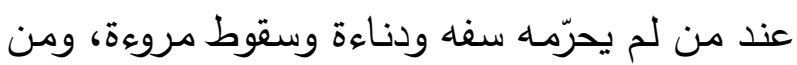

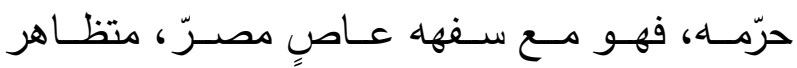
بفسوقه، ... ومن كان يغشى بيوت الغناء، أو يغشاه

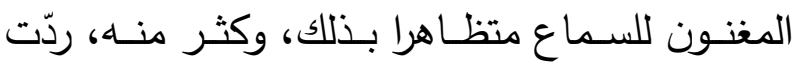

المقدس، تحقيق زهير الثـاويش، طب (بيروت: المكتب الإسـامي -

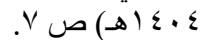

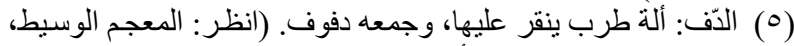

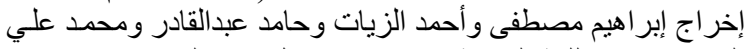

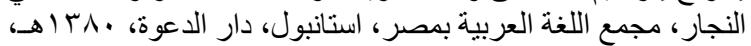

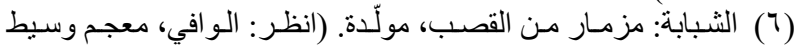

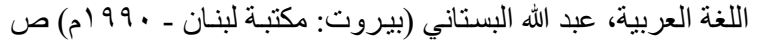

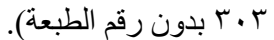

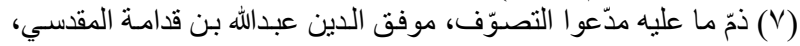

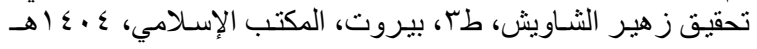

فقد وردت أحاديث كثيرة تتصّ على تحريخ الغناء، منها:

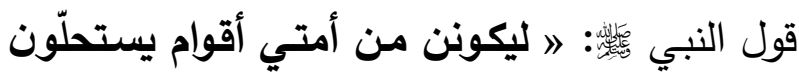
الحر، والحرير، والخمر وإلمعازف... « (').

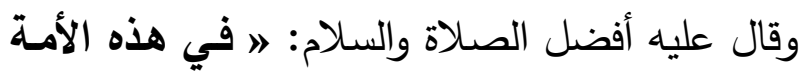
خسف ومستخ وقذف، فقال رجل من المسلمين: يا

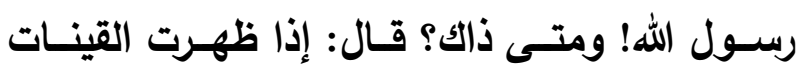

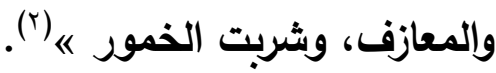

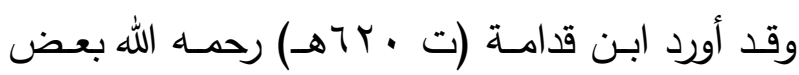
أقوال الأئمة في حكم هذا السماع ومنها: 1- قول الإمام احمد: (التغبير (r) محدث)، وقوله وقد ومنا:

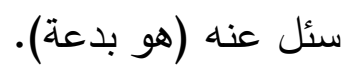
r- قول الإمام الثافعي: (تركت بالعراق شيئا يقال

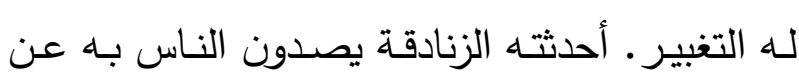

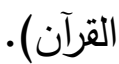
r- قول يزيد بن هارون: (ما يغبر إلا فاسق، ومتى

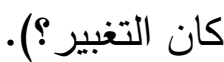
ع- قول عبد الله بن داود: (أرى أن يضرب صاحب) التغبير ) (§)

(1) صحيح البخـاري، كتاب الأشربة، بـاب مـا جاء فيمن يستحل الخمر

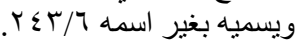
(Y) سنن الترمذي، ضبط ومر اجعة أصول وتصديح عبدالرحمن عثمان،

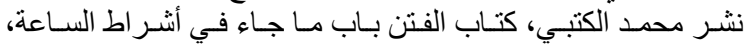

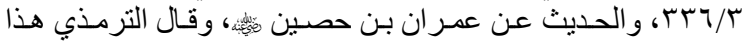

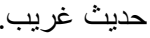

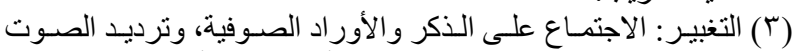

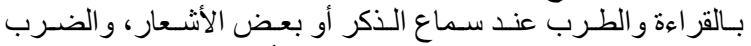

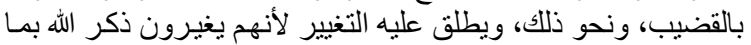

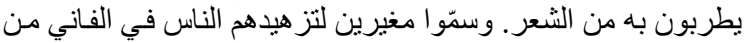

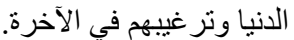

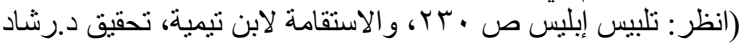

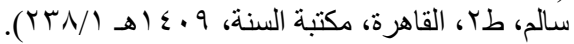

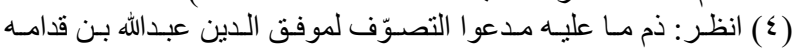


الثانـي: أنـه يميلـه إلى اللذات العاجلـة، ويـدعو إلى اسـتيفائها مـن جميـع الثــهوات الحسّـية، ومعظمهـا النكاح، وليس تمام لذته إلا في المتجددات ولا سبيل إلى كثرة المتجددات مـن الحل، فلـلك يحثّ على إلى الزنا، فبين الغناء والزنى تناسب من جهة أن الغناء

لذّة الروح والزنى أكبر لذات النفس"(؟).

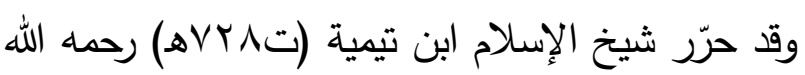
موقف السلف من أهل السنة والجماعة من دعوى السماع عندما سئل رحمه الله عنه، موضحًا السماع مواع

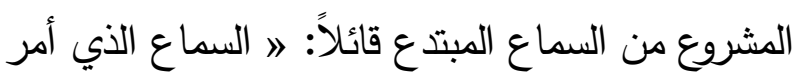
الله به رسوله واتقق عليه سلف الأمة ومشايخ الطريق هو سماع القرآن، فإنه سماع النبيين وسماع العالمين

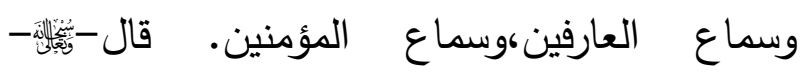

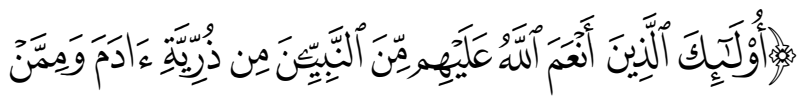

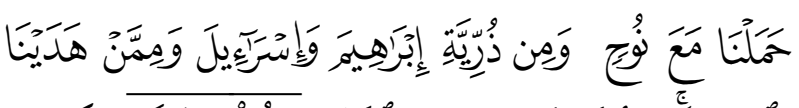

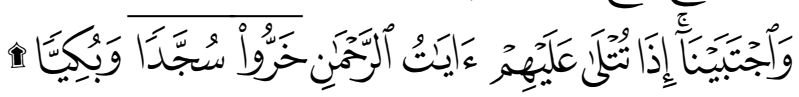

$$
\text { [01: مريم: }
$$

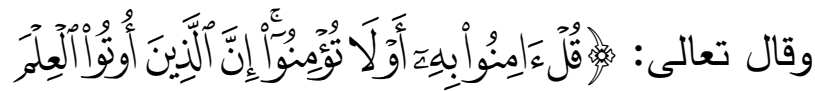

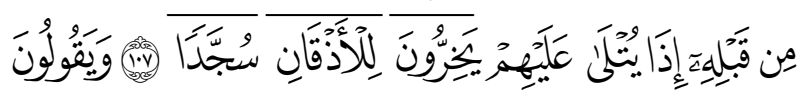

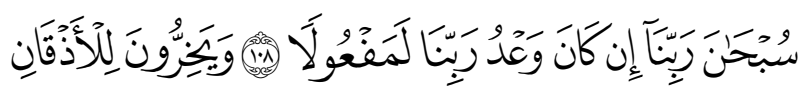

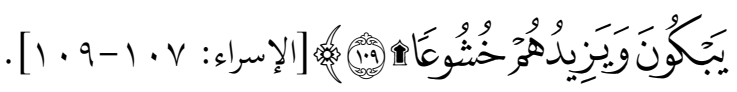
وقال تعالى :

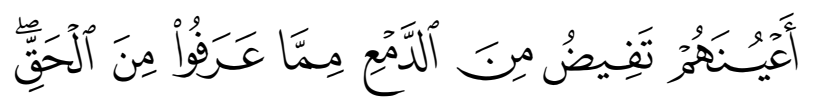

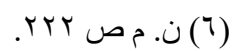

شهادته في قولهم جميعا، لأنه سفه ودناءة «"('). وقد أنكر محمد بن سيرين (ت • 1 (اهـ) رحمه الله هذا السـماع فقد ذكر عنده: 》 الذين يصـرعون إذا قرئ القرآن، فقال بيننا وبينهم أن يقف أحدهم على ظهر بيت باسطًا رجليه، ثم يقرأ عليه القرآن من أوله إلى آخره، فإن رمى بنفسه فهو صادق (r).

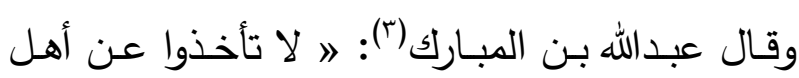
الكوفـة في الـرفض شـينًا، ولا عـن أهـل الثــام في السيف شينًا، ولا عن أهل البصرة في القدر شينًا، ولا عن أهل خراسان في الإرجاء شيئًا، ولا عن أهل مكة

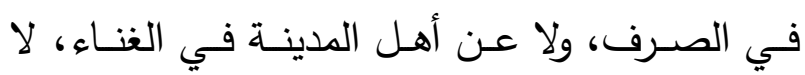
تأخذوا عنهم في هذه الأشياء شينًا ه(؛). وهذا ابن الجوزي (ت وهـهـ) يذكر أقوال أصحاب

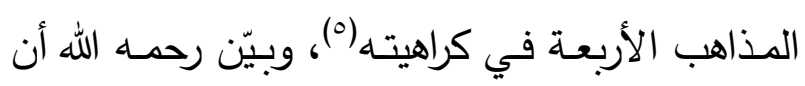
سماع الغناء يجمع شيئين: أحدهما: أنـه يلهي القلب عـن التقكر في عظمـة الله تعالى، والقيام لخدمته.

( (1) المغني، لابن قدامـة، الريـاض، مكتبـة الريـاض الحديثة، إ. أهـ،

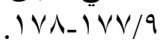

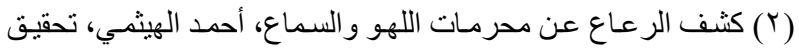

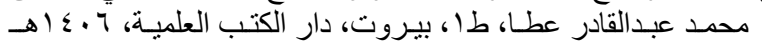

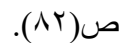

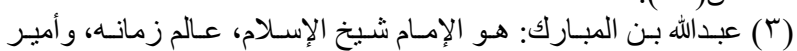

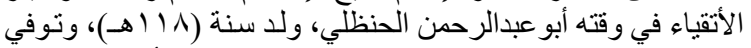

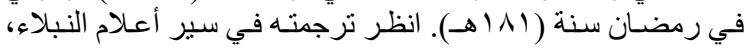

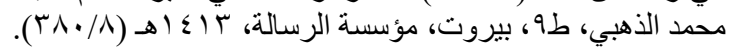

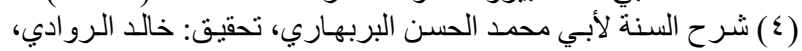

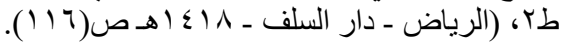

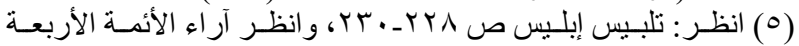

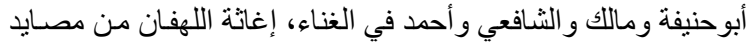

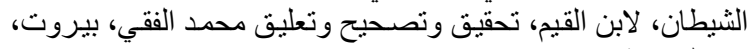

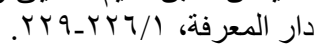


عنه معذورًا لكن سبب ذلك قوة الوارد على قلوبهم وضعف قلوبهم عن حمله فلو لم يؤثر السماع لقسوتهم كانوا مذمومين كما ذَّ الله الذين قال فيهم:

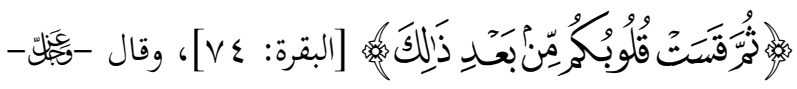

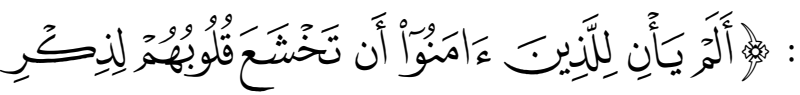

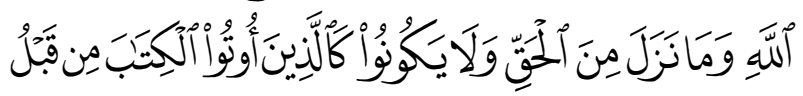

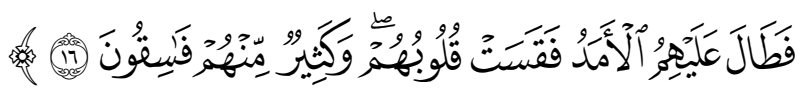

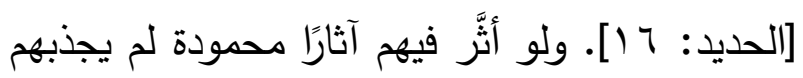
عن حدِّ العقل لكانوا كمن أخرجهم إلى حدِّ الغلبة كانوا محمودين أيضًا ومعذورين. فأما سماع القاصدين لصلاح القلوب في الاجتماع على لى ودين ذلك: إما نشيد مجرد نظير الغبار وإما بالتصفيق ونحو التهو

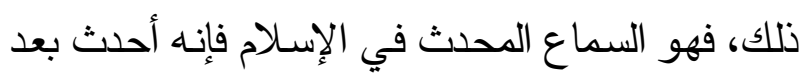

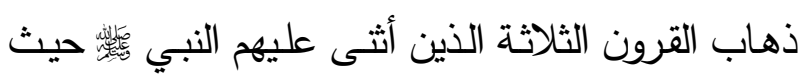

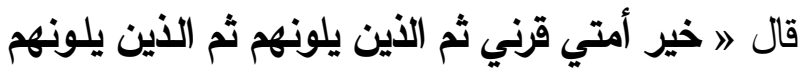
" ")، وقد كرهة أعيان الأمة ولم يحضره أكابر المشايخ.

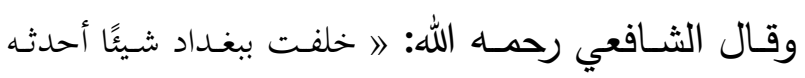
الزنادقة يسمونه التغبير يصدون به الناس عن القرآن «ا

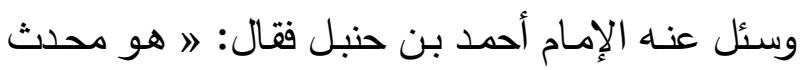

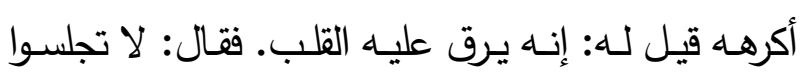

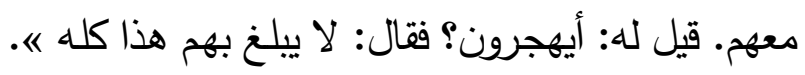
فبيَّن أنه بدعة لم يفعلها القرون الفاضلة لا في الحجاز لهاز ولا في الثام ولا في اليمن ولا في مصر ولا في العراق

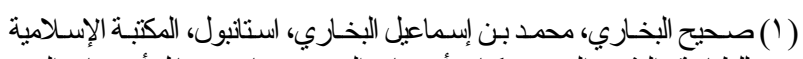

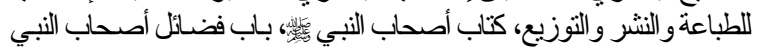

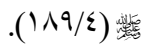

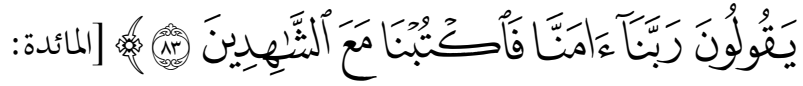
. [ᄉ

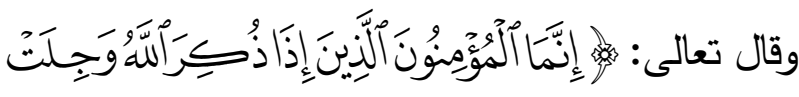

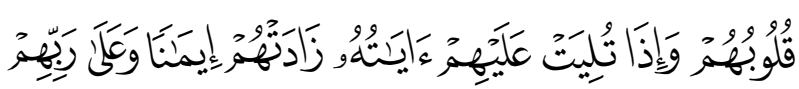

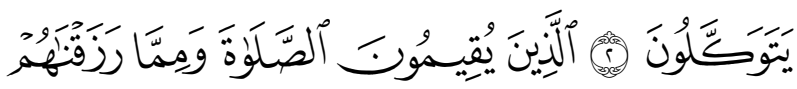

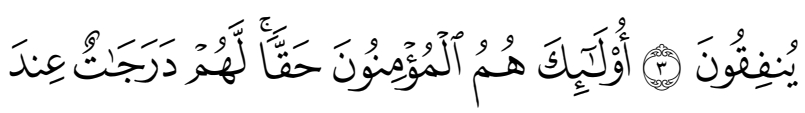

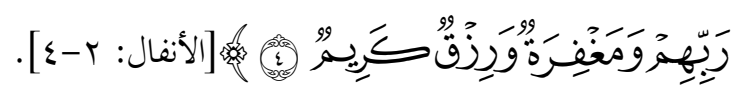
إلى أن قال -رحمه الله-: " وكما أثنى الله على هذا السماع فقد ذم المعرضين عنه وساق بعض الى الآيات

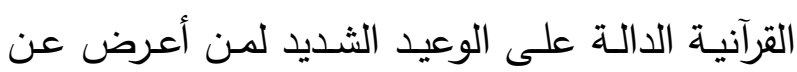
سماع القرآن الكريم ثم قال:

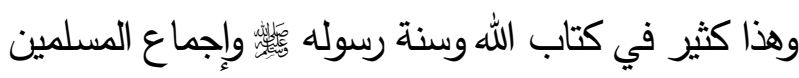
يمدحون من يقبل على هذا السماع ويحبه ويرغب فيـه ويذمون من يعرض عنه ويبغضها.

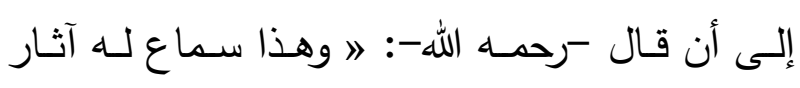
إيمانية من المعارف القدسية والأحوال الزكية يطول

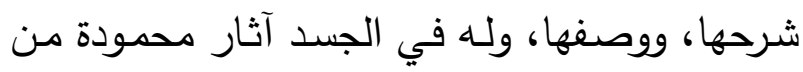

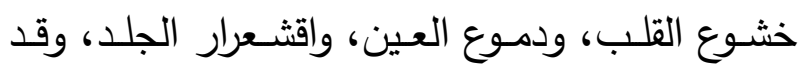
ذكر الله هذه الثلاثة في القرآن، وكانت موجودة في ودي أصحاب رسول الله

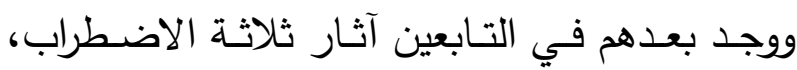

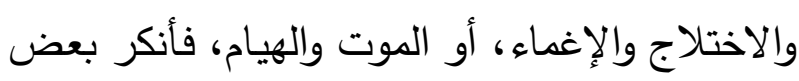
السلف ذلك إما لبدعتهم وإما لحبهم. وأما جمهور الأئمة والسلف فلا ينكرون ذلك فإن فان السبب إذا لم يكن محظورًا كان صاحبه فيما تولَّد 
عندما ورد عليـه سؤال جـاء فيـه: 》 مـا تقول السـادة الفقهـاء ... فـيمن يسـمع الـدف والثـبابة، والغنــاء ويتواجد حتى أنه يرقص.... مع اعتقاده أنه محب الله، وأن سماعه وتواجده ورقصه في الله؟.

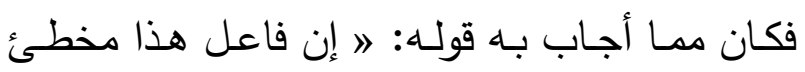
ساقط المروءة، والدائم على هذا الفعل مردود الثهادة في الشـرع غير مقبول القول، ومقتضـى هذا أنـه لا تقبل روايتهـ... ولا شهادته برؤيـة هـلال رمضـان، ولا أخباره الدينية.

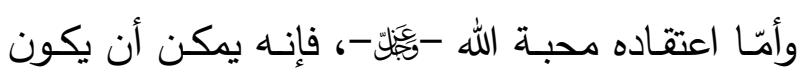
محبًا لله سبحانه مطيعًا لله في غير هذا.... وأمّا هذا

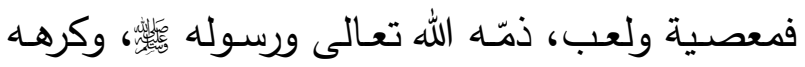

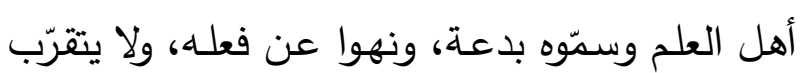
إلى الله سبحانه بمعاصيه، ولا يطاع بارتكاب مناهيه. ومـن جعل وسـيلته إلىى الله سـبحانه معصـيته، كان حظه الطرد والإبعاد، ومن اتخذ اللهو واللعب دينًا،

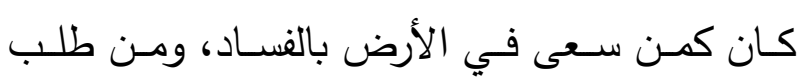

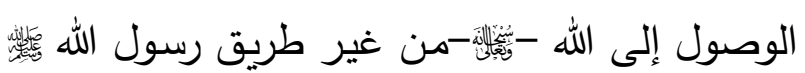
وسنتّه، فهو بعيد من الوصول إلى المراد «(r).

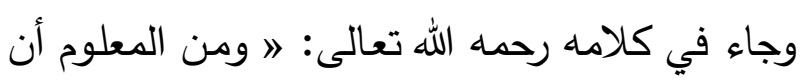
رسـول الله

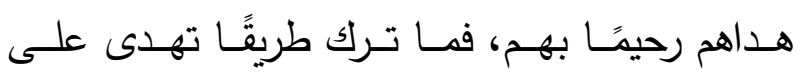
الصواب إلا وشرعها لأمته، ودلهم عليها بفعله قوله، وكـان أصـحابه مـن الحـرص على الخيـر والطاعـة

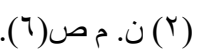

ولا خراسان ولو كان للمسلمين به منفعة في دينهم لفعله السلف ولم يحضره مثل إبراهيم بن ادهم ولا الفضيل بن عيـاض ولا معـروف الكرخي، ولا السـري السـطي، ولا أبوسـليمان الـداراني، ولا مثنل الثـيخ عبـدالقادر والثـيخ عدي، والثيخ أبي البيان، ولا الثيخ حياة وغيرهم بل في كلام طائفة من هؤلاء كالثـيخ عبدالقادر وغيره النهي عنه وكذلك أعيان المشايخ «. إلى أن قال -رحمـه الله-: 》 وبالجملة فعلى المؤمن

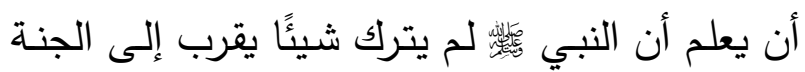

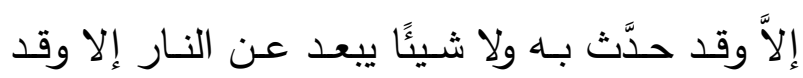
حدَّث به وإن هذا السماع لو كان مصلحة لشرعه الله

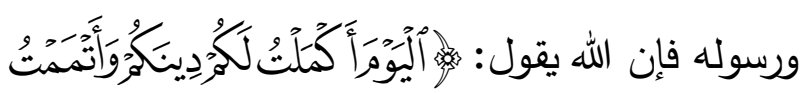

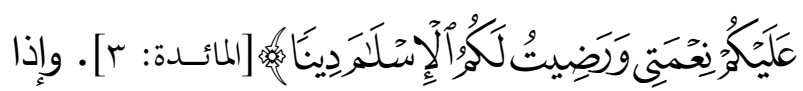
وجد فيـه منفعـة لقلبـه ولـم يجـد شـاهد ذلـك لا مـن الكتاب ولا من السنة لم يلتفت إليه «"('). - العلماء ودعوى أن السماع قربة إلى الله: عندما اعتقد الصـوفية، أن السماع، وما يترتب عليه من آثار ، إنما يفعلونه، قربة إلى الله، زاعمين أنه من

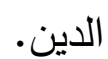
واجـه هذا الاعتقاد، ردّا، وإنكارًا، وتحذيرًا من علمـاء

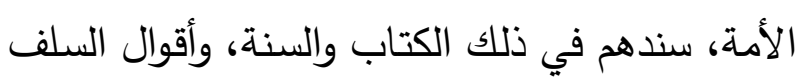
الصالح. فقد شدّد الإمام موفق الدين ابن قدامة المقدسي رحمه الله، إنكاره على الصوفية في هذه الدعوى، وكان ذلك 
وقال رحمـه الله وهو يرد على ابن الحنبلي إباحته

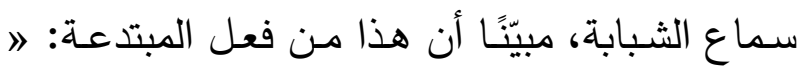
ومن العجب، استدلال الفقيه على إباحة الثبابة. بأنه قد سمعها من الصوفية، وما من قبيحة من القبائح،

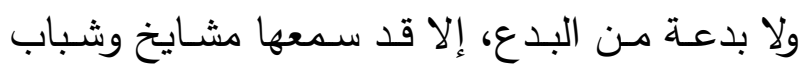
أيضًا،

وقد علم الناصح -أي ابن حنبلي - أنواع الأدلة، فهل وجد منها فعل المشايخ من الصوفية؟، وإن كان هذا لإنا

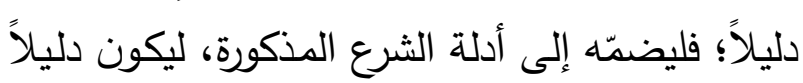

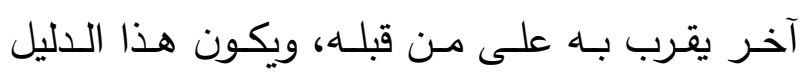

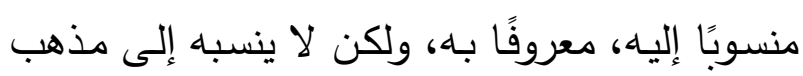

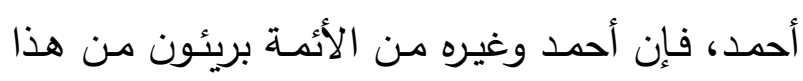

وكان الحافظ عبدالغني الدقدسي (ت . . بهـ) قويًا في أمر الله، وكثيرًا ما كان بدمشق ينكر المنكر، ويكسر الطنابير والثبابات (i).

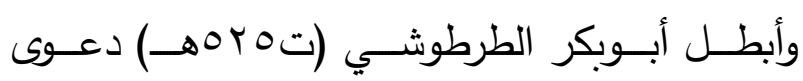

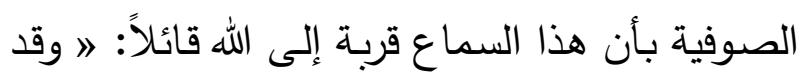
كان الناس فيما مضى يستتر أحدهم بالمعصية إذا

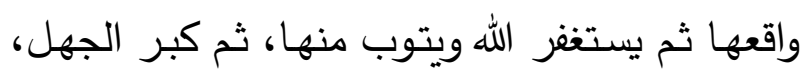
وقل العلم، وتتاقص الأمر ، حتى صار أحدهم يأتي

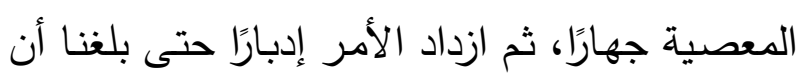

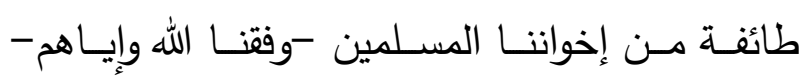

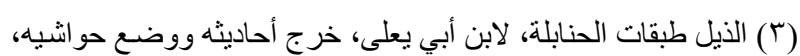

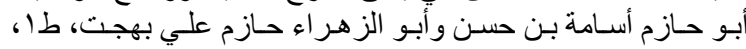

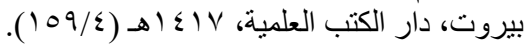

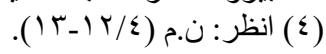

والمسـارعة إلى رضوان الله بحيث لم يتركوا خصلة

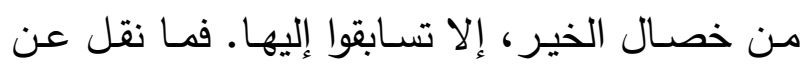

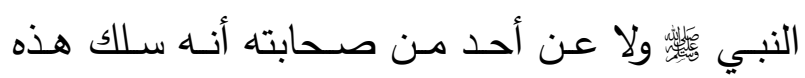
الطريقة الرديئة، ولا سهر ليله في سماع يتقرّب بـه

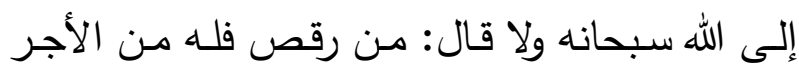

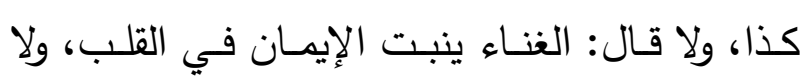

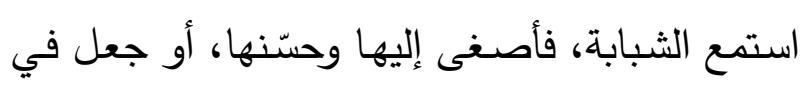

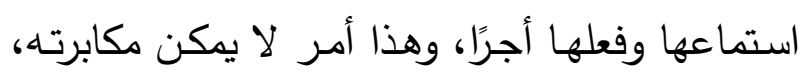

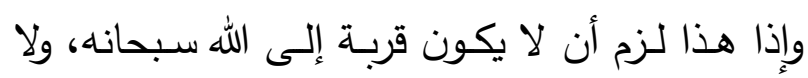
طريقًا موصلاً إليه، ووجب أن يكون من شر لأن الأمور (')

وقال رحمه الله منكرًا على الصوفية في ذلك: 》 فأمّا من يجعله -أي ضرب الدف ونحوه- دينًا، ويجعل دأل

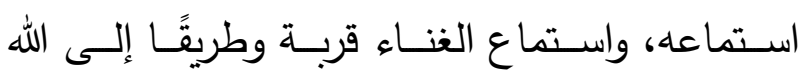

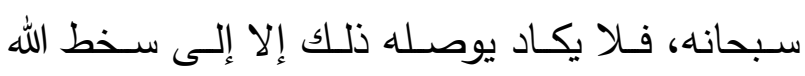

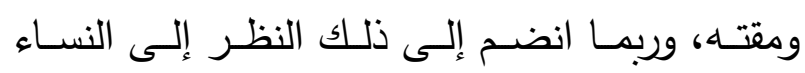

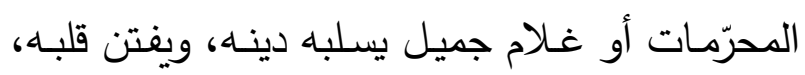

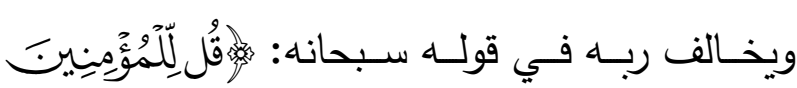

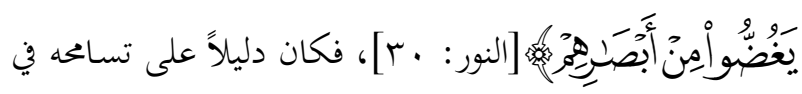

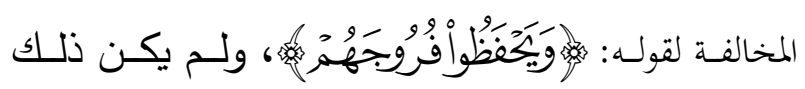

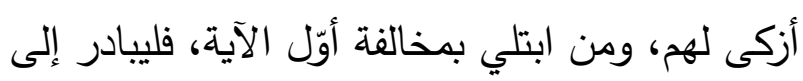

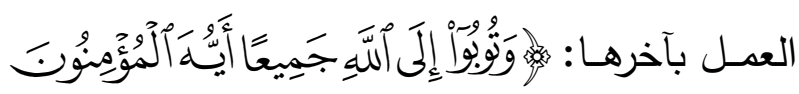

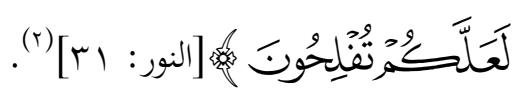
(1) (1) ن. م ص(1) (1) (1) (1) (1)

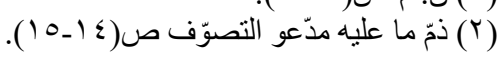




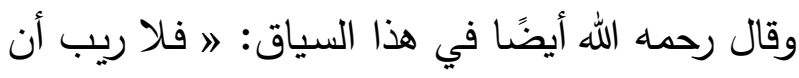

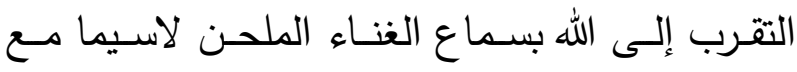

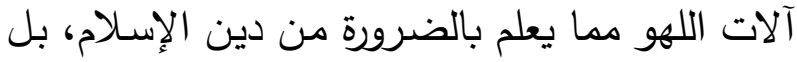

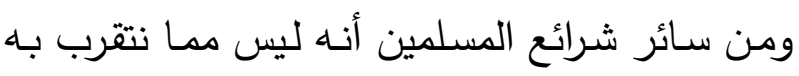
إلى الله، ولا مما تزكَّى به النفوس وتطهر من أدناسها وأوصارها، ولم يشرع على لسان أحد من الرسل في

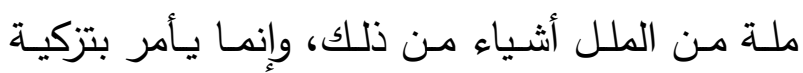

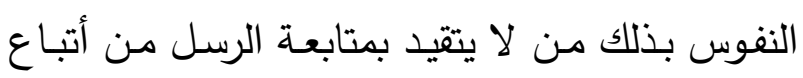

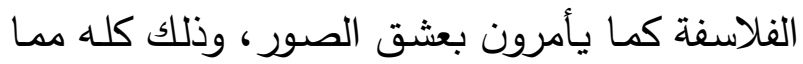

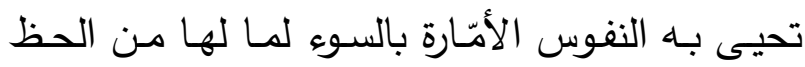
ويقوى به الهوى وتموت به القلوب المتصلة بعلام

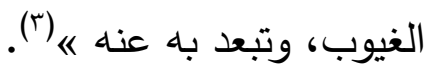
وقال ابن كثير (ت ؟ \هـ) في تفسير قوله تعالى:

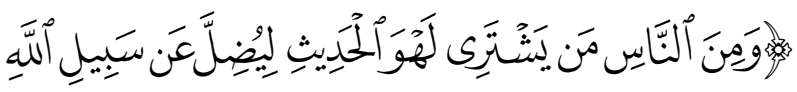

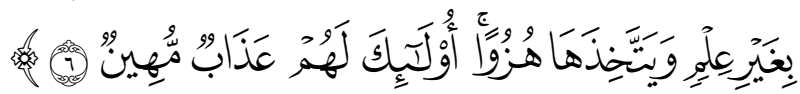
(3) [قمان: 17 إن لهـو الحـديث هـو: الغنـاء، وذكر أن المعسازف واللعب واتباع الثهوات، وكل ما يصد عن ذكر الله، هي ما كانت تتلو الشياطين (०). وقـال رحمـه الله في وصـفه ســاع الصـوفية؛ بأنـهـ ســاع شـيطاني، فقـال ترجمـة الثـيخ أبـو الرجـال

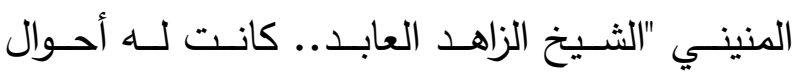
ومكاشفات.. وكانت له زاوية بيلده، وكان برينًا من لئن

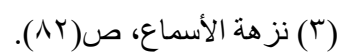

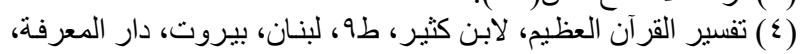
r (

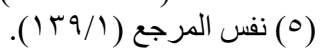

استنزلهم الثيطان واستهوى عقولهم في حب الأغاني

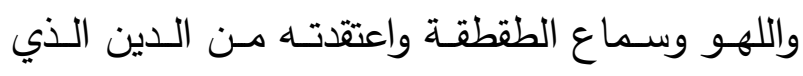

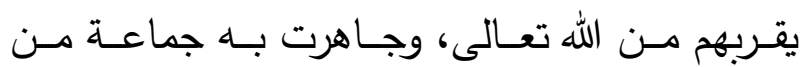
المسلمين 《) (1). وأنكر ابن رجب (ت ألونهـ) رحمه الله على الصوفية

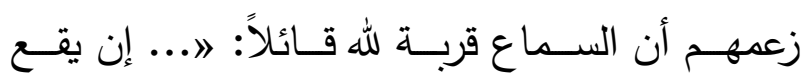

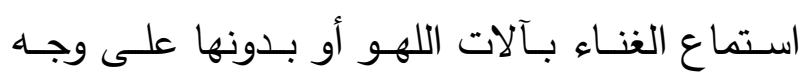

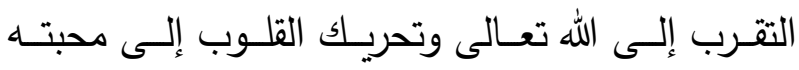
والأنس به والثوق إلى لقائه، وهذا هو الذي يدعيه كثير

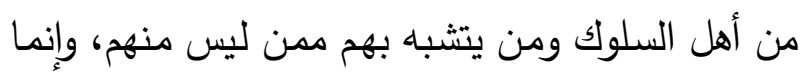

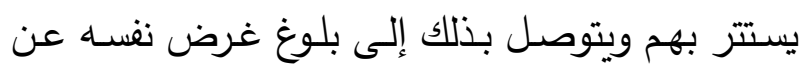
نيل لذته، فهذا المتشبه بهم مخادع مُلبِّبس وفساد حاله أظهر من أن يخفى على أحد.. «.ثم بين رحمال الله

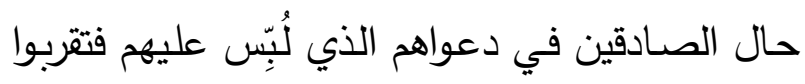
إلى الله بما لم يشرعه الله واتخذوا دينًا لم يأذن الله فيه فلهم نصيب ممن قال الله فيه:

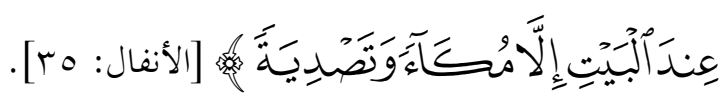

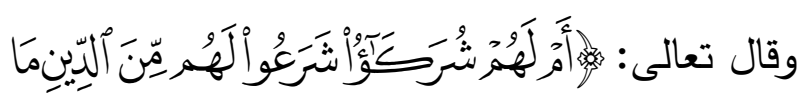

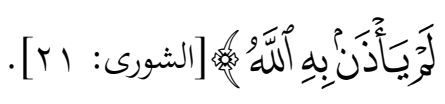

فإنها إنما يتقرب إلى الله بما يشرع التقرب بـه إليها على لسان رسوله، فأما ما نهى عنه فالتقرب بها إلى إليه مضادة لله في أمره «(r)

$$
\text { ( (1) المدخل لابن الحاج (ب/ • ( ). }
$$

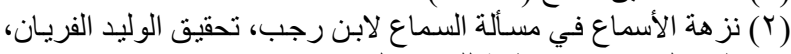

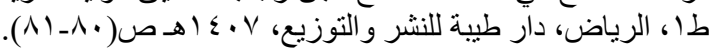


قال شيخ الإسـلام ابن تيميـة رحمـه الله في معرض إنكاره على الصوفية: 》 وأمسا اتخاذ التصفيق والغناء والضـرب بالدفوف، والنفخ في الثـبابات والاجتمـاع على ذلك دينًا وقربـة وطريقًا إلى الله، فهذا ليس من

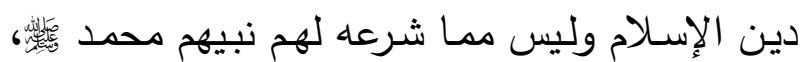
ولا أحد من خلفائه، ولا استحسن ذلك أحد من أهل

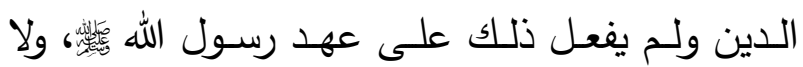
عهــد الصـــحابة ولا تــابعيهم بإحســان ولا تـابعي التـابعين، بـل لـم يكـن أحــــــن أهـل الـدين مـن الأعصــار لا بالحجــاز ولا بالثــام ولا بـاليمن، ولا العراق ولا خراسان ولا المغرب ولا مصر يجتمع على مثل هذا السماع وإنما ابتدع في الإسـلام بعد القرون الثلاثة، ولهذا قال الثـافعي لمـا رأى ذلك: \ خلفت ببغداد شيء أحدثته الزنادقة «(•).

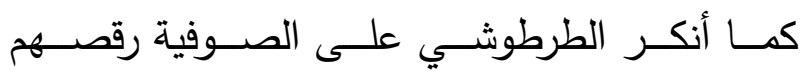
وتواجدهم، وعدّ ذلك من البطالتة والجهل والضـلال، وقال أنه دين الكفّار وعبَّاد العجل، قال ذلك ردًا على سؤال وجـه لـه، جـاء فيـه: مـا يقول سيدنا الفقيـه في مـذهب الصـوفية؟ وأعلمع... أنـهـ اجتمـع جماعـة مـن رجال، فيكثرون من ذكر الله تعالى، وذكر محمد ؛. ثم إنهم يوقعـون بالقضـيب على شـيء مـن الأديـم، ويقوم بعضـهم بـالرقص ويتواجـ حتى يقـع مغشـيا عليه، ويحضرون شيئا يأكلونه، هل الحضور معهم جائز أم لا؟ أفتونـا مأجورين يرحمك الله، وهذا القول

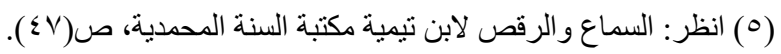

هذه السماعات الشيطانية"(1) . (1) وقال ابـن تيميـة رحمـه الله في معرض إنكـاره على هـؤلاء المبتدعـة: \... كثيـر مــن الأثــعار التـي يسـعها أهـل الســاع -الصـوفية-، قد يتضـمن مـن الكذب على الله، والتكذيب بالحق: أنواعًا «(؟). وأضاف: وصار من هؤلاء من يُنشد أشعار الفساق، والفجار ، والكفار ، بـل وينشدون مـا لا يستجيزه أكثر أهل التكذيب، وإنمـا يقولـه: أعظم النـاس كفرًا بـرب العـالمين، وأشـدهم بُعـدًا عن الله ورسوله، والمؤمنين وزادوا على ذلك في أنواع الآلات، ما زادوا بـه الفتنة، حتى ربـا فيهـا الصـغير، وهـرم فيهـا الكبيـر، حتى حتى اتخذوا ذلك دينًا وعادة، وجعلوا من الوظائف الراتبـة، بالغـداة، والعشـي، كصــلاة الفجـر ، والعصـر ، وفي الأوقـات، والأمـاكن، الفاضــلات، واعتاضــوا بـه عـن

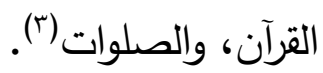
وقال القاضـي أبوالطيب طاهر الطبري (ت • 0ـهـ) رحمـه الله: 》 اعتقــاد هـذه الطائفــة مخـالف لإجمـاع علمـاء المسـلمين، فإنـهـ لـيس فيهم مـن جعلـه دينًا وطاعة ولا روى إعلانه في الجوامع والمساجد، وحيث كـان مـن البقـاع الثـريفة والمشـاهد الكريمــة، فكـان مذهب هذه الطائفة مخالفًا لما اجتمعت العلماء عليه ونعوذ بالله من سوء التوفيق(؟).

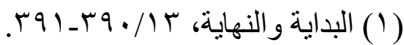

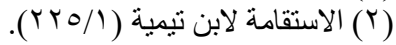

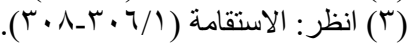

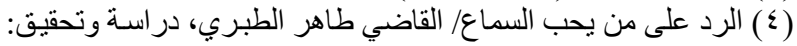

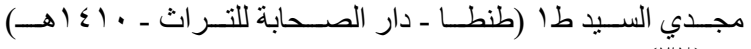

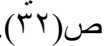


بأدنى فكره: إن الرقص بالحركات الموزونـات على ألحان الغناء والقينات وتقطيع المزامير والطارات من أفعـال أهـل المجـون والبـاطلات، وإن ذلك لا يليـق بـالعقلاء ولا يناسـب أحـوال الفضـلاء، ولـذلك قـال الجنيد: 》 الرقص نقص « وقال الغزالي: \ الرقص وه حماقة، ....، وذلك أن العقلاء بما هم كذلك ينزهون أنفسهم عن مشابهة السفلة الطغام ومشاكلة الصبيان والنسوان وعن الاتسـام بسمة المخانيث أهل الفسوق والعصيان «.

حتى قال: ا ومن الذي يرضى لنفسـه بذلك أو يدخل في شـيء ممـا هنالـك: كـلا والله لا يرضـى بـذلك ئك عاقل، ولا يتعاطـاه فاضل، ثم أي فائدة تحصل فيـه في الدنيا، أو أي ثواب يترتب عليه في الأخرى، وإذا عرى عن ذلك تحقق أنه عبث وهوى «. إلى قوله: "ا... ولذلك لم ينقل من نبي من الأنبياء، ولا ولي من الأولياء، ولا عـالم مـن متقدمي العلمـاء القول بإباحـة الرقص على المزامير والأوتار ، وهـز المناكب والأرداف كلما صلصل الدف والطارة ومن ادعى نقل شيء من ذلك عن من يوثق بعلمه ويرجع إلـى فتــواه وفهمــه طالبـــاه بتصــحيح نقلـه وإثبــات قولله (r)

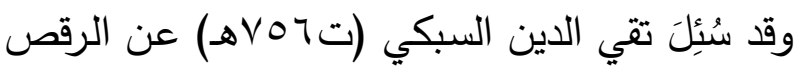
والدف وعن حضور السماعات، فأجاب عنه بقوله:

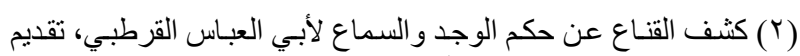

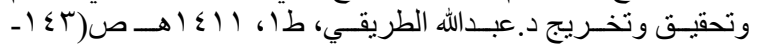

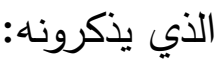
يا شيخ كف عن الذنوب قبـلـل التفـرق والـزلل

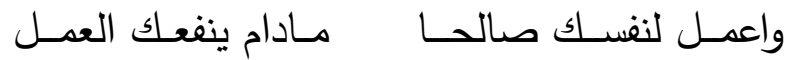
أمـا الشباب فقد مضـى ومشيب رأسك قد نزل وفي مثل هذا ونحوه. فأجـاب رحمــه الله: مـذهب الصــوفية بطالـة وجهالـة

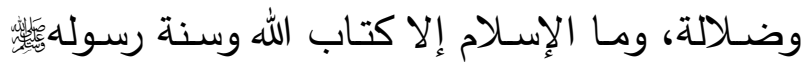

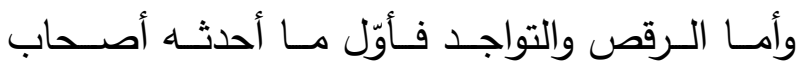
السـامريّ، لما اتخذ لهم عجدلا جسدا لـه خوار قاموا يرقصون حواليه ويتواجدون؛ فهو دين الكنّار وعبّاد العجل، وأما القضيب فأول من اتخذه الزنادقة ليشغلوا به المسلمين عن كتاب الله تعالى، وإنما كان مجلس النبي الوقـار ، وينبغـي للســلطان ونوابــه أن يمنعـوهم مـن الحضور في المساجد وغيرها؛ ولا يحل لأحد يؤمن بالله واليوم الآخر أن يحضر معهم، ولا يعينهم على باطلهم؛

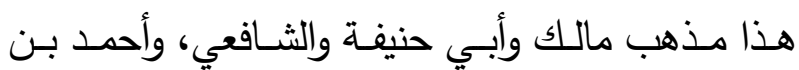
حنبل وغيرهم من أئمة المسلمين وبالله التوفيق «" ('). وأنكر أبوالعباس القرطبي (ت 707هـ) على الصوفية رقصهم، وعدَّه من المبتدعات في الدين يقول: 》 لا يخفى على من لـه من العقل أدنى مسكه، إذا تأمل

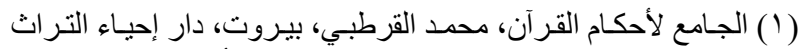

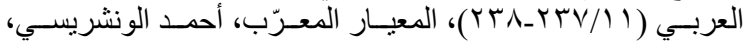

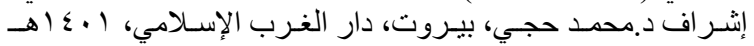

(17r-174/11) 
الإنـلام بالدين، يزعمون أنهم خواص الإنسلام، قضوا حياتهم لذة وطربًا، واتخذوا دينهم لهوًا ولعبًا، مزامير

الثيطان أحب إليهم من استماع سور القرآن «آ (T). وقال الإمام ابن القيم رحمه الله في معرض رده وإنكاره

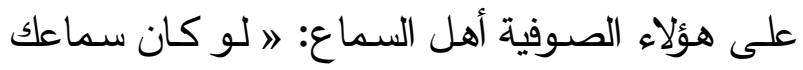

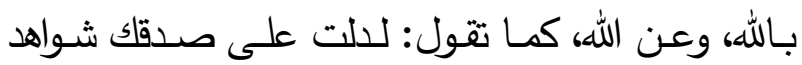
ذلك: من سماع كلامـه وأسمائه، وصفاته، ومواعظه،

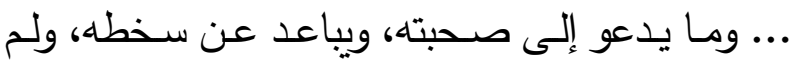
يكن سماعك، لثيء لا يشاربه إلى الخالق، وإنما يشار

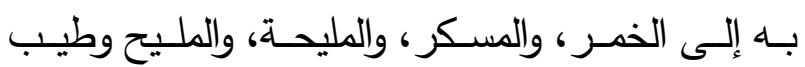

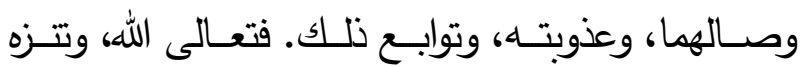

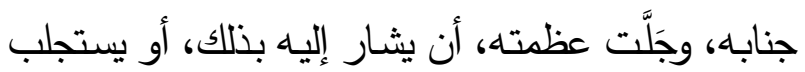

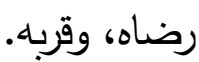

كلا والله، إن استجلب بذلك، إلا مقته، والبعد منه. وكيف يجوز أن توجد الإثارات إلى الله سبحانه، والتغزل في النساء والمردان، وأين هذا مما يجب لهات له سبحانه-

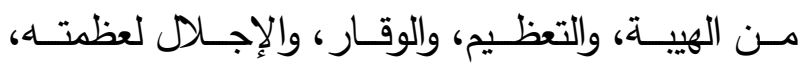
وخشيته، والخوف منه؟ وقد آل بهم هذا إلى أن أطلقوا

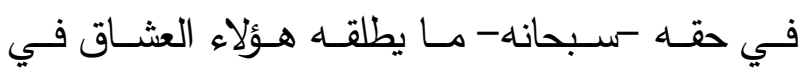
معشوقيهم، من الصد، والهجر، والوصسال، وتوابع نلك، ونثأت من ذلك الثطحات، والطامات، والرعونات التي التي

$$
\text { هي ضد طريق العبودية «() أن. }
$$

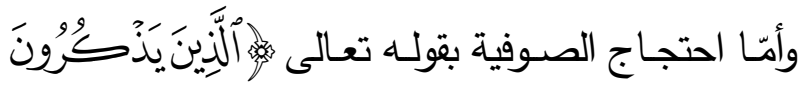

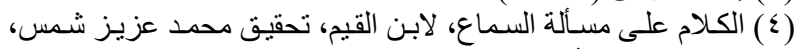

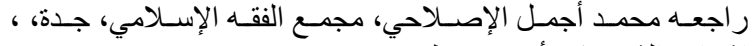

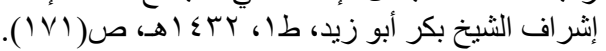

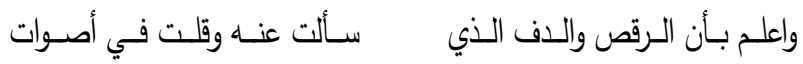

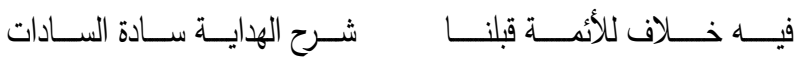

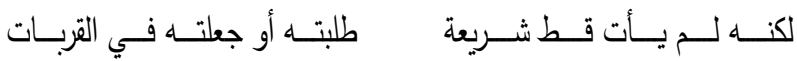

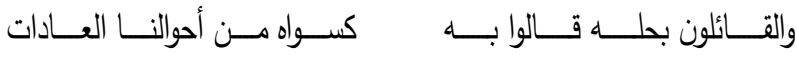

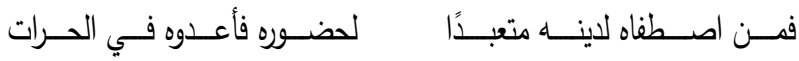

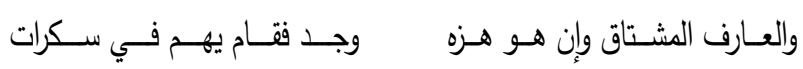

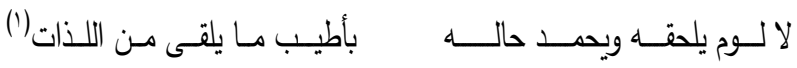
وعدَّ الآجري (ت • بسه): الذي يحضر الأفراح التي

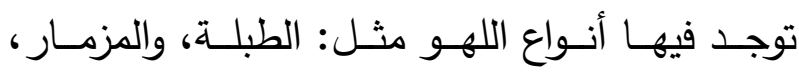
والمعـازف، والعـود، والطنبور ، والمغنـي، والمغنيات،

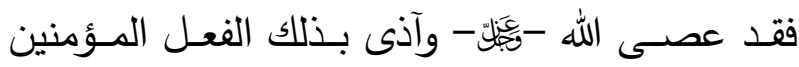
فيكثر الدعاء عليه تقبيح ما أظهر مما نهى عنه(؟). وقال الإمـام ابن القيم (ت المVهـ) في الذين يستمعون الغناء وآلات اللهو ويرقصون على أنغامها من الصوفية: " فلـو رأيـات عنــد ذيـالك السـماع وقـــ خشـعت مـنهم الأصوات وهدأت منهم الحركات، وعكفت قلوبهم بكليتها عليـه، وانصـبت انصـبابة واحـدة إليـه، فتمـايلوا لـه ولا كتمايل النشوات، وتكسروا في حركاتهم ورقصهم، أرأيت تكسر المخانيث والنسوان؟ ويحق لهم ذلك، وقد خالط حماره النفوس، فقعل فيها أعظم ما يفعله حُمَّيا الكؤوس، فلغيـر الله، بـل للثـيطان، قلـوب تمـزق وأثـواب تشـقق وأموال في غير طاعـة الله تتفق، ... ويـا شماتة أعداء

( (1) كف الر عاع عن محرمات اللهو والسماع لأبي العباس أحمد بن حجر الكبر

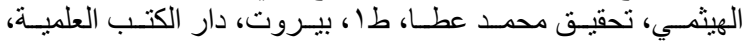

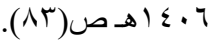
(Y) انظر كتاب الثريعة لأبي بكر محمد الآجري، تحقيق محمد إسـاعيل

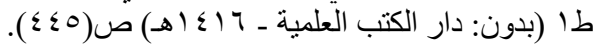


ولما تعقت الصوفية في القيام والقول بقوله تعالى

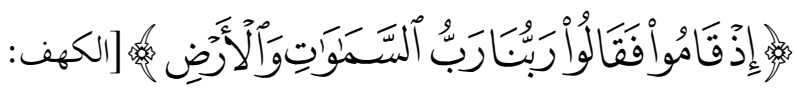
ع ا ]، مستدلين بذلك على رقصهم وتزيقهم الثياب.

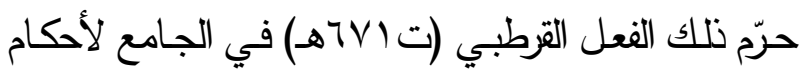
القرآن بقوله: \هذذا تعلق غير صحيح، هؤلاء قاموا فككروا

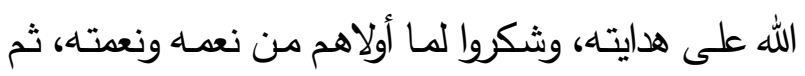
هاموا على وجوههم منقطعين إلى ربهم خائين من قومهم، وهذه سنة الله في الرسل والأنبياء والفضلاء والأولياء.

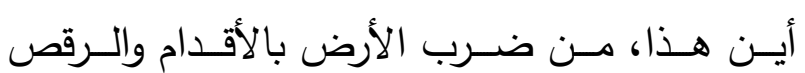

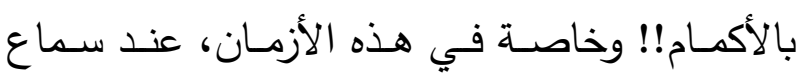
الأصـوات الحســان مـن الهـرد والنســوان! هيهـات؛ بينهما -والله- ما بين الأرض والسماء. ثم هذا حرام عند جماعة العلماء «|"(r).

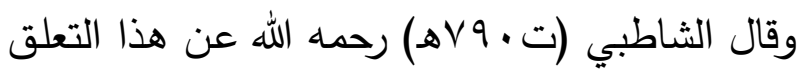
الصوفي بهذه الآية: » أين فيه أنهم قاموا يرقصوا، الهاء

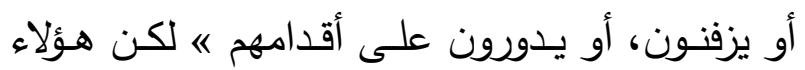

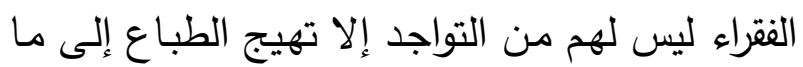

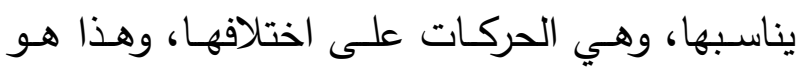

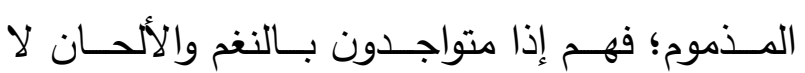

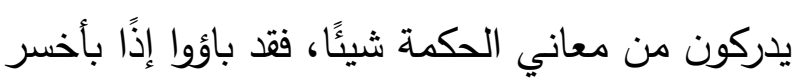
الصفقتين نعوذ باللها("). وقد ردّ ابن قدامة رحمـه الله تعالى على بعض شباله المجيزين للغناء -ومنهم الصوفية- في رسالته إلى بلى بلى

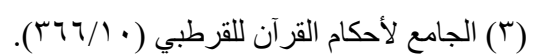

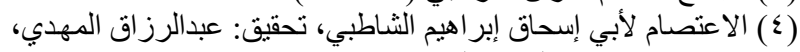

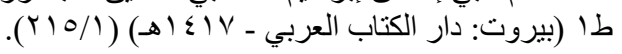

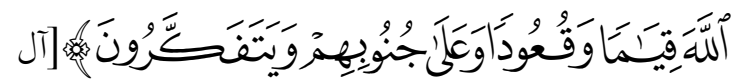
عمران: ا9 19] على بدعهم وغنائهم وتمايلهم، فهو في في الحقيقة؛ بعيد جدا ومردود لأسباب منها:

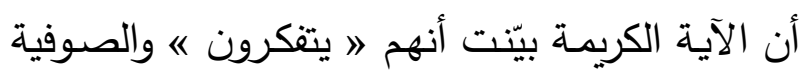

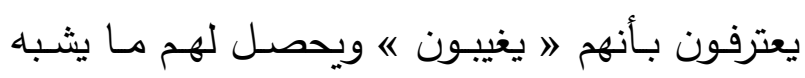
السكر والغيبة. أن الآية الكريمة ذكرت أنهم يذكرون الله على جنوبهر أيضا، والصوفية إنما يتمايلون قياما وقعودا. أن السلف الصالح كانوا يعملون بما في القرآن، ولم

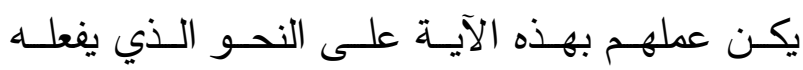
الصوفية، ولا فعله رسول الله

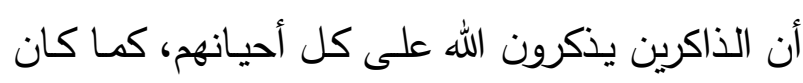

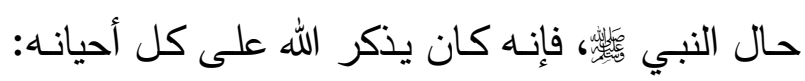
قائما وقاعدا، وعلى جنبيه.

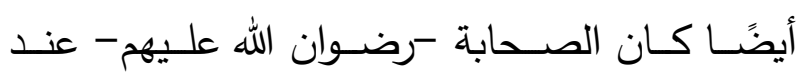

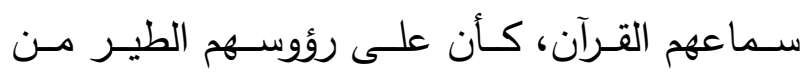
الخشية، وما كانوا يزيدون على البكاء والخشوع. ففي حديث العرباض بن سارية ضئه قال: " وعظنا رسول

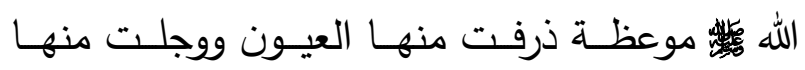
القلوب 《) (1) قال أبوبكر الآجري: 》 ولم يقلْ: صرخنا، ولا ضربنا صدورنا، كما يفعل كثير من الجهَّال الذين يتلاعب بهم الثيطان «(†).

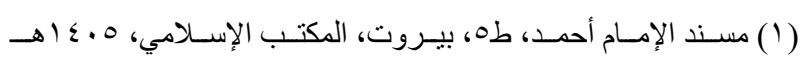

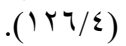
(Y) تلبيس إبليس ص(Y) (Y) (Y). 
اضطجع على فراشه، وحوّل وجهه عنهما، فلو كان

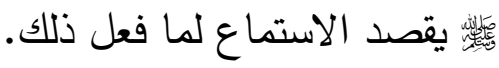
ثم يرد عليهم احتجاجهم بهذا الحديث؛ بإنكار أبي بكر

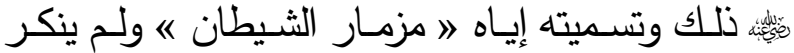

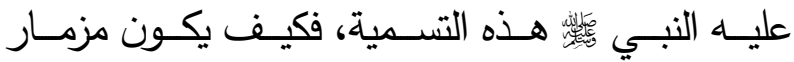
الثيطان قربة وطاعة إلى الله ؟!.

ثم إن الجويريتين صغيرتان، دون البلوغ، غير مكلفتين،

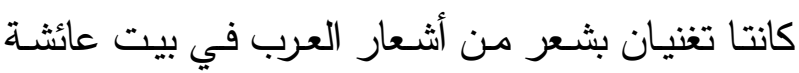
رضي الله عنها، وهي صغيرة وسماع الصوفية وأشعارهم بخـلاف هذا، فكيف يقاس فعل الجاريتين بمـا تفعلهـ الصوفية في حلقات السماع من الرقص؟!. قال ابن تيمية: فهذا قياس فاسد وتشبيه للثيء بما ليس التهائ مثله (i) كذلك رد طـاهر الطبري احتجاجهم بحديث عائشـة

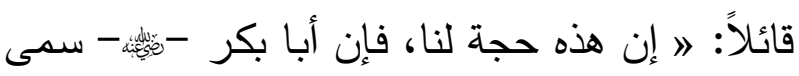

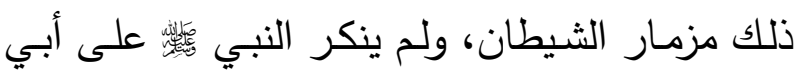

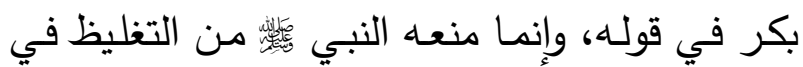
الإنكار ، والتسرير للصبايا الذي هو يوم السرور . لأنسا

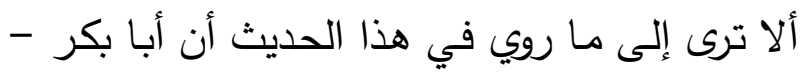

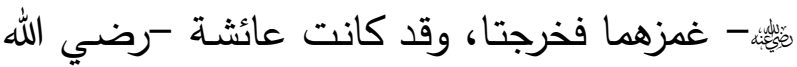

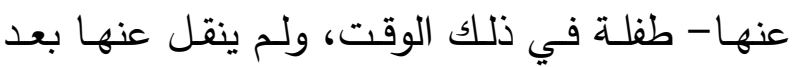
بلوغها، وتحصيلها إلا ذم الغناء، والمعازف. وقد كان ابن أخيها القاسم بن محمد، وهو أحد فقهاء

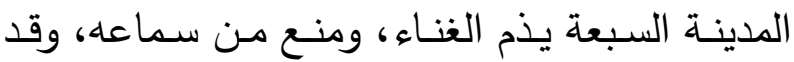

( ) انظر : الاستقامة لابن تيمية ( ( ( ) ).
ابن الحنبلي التي أنكر فيها إباحته لبعض أنواع

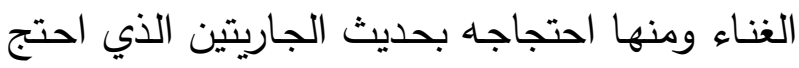
به الصوفية قائلا: " وأمّا استدلالهم بحديث الجواري اللاتي ندبن آباءهن،

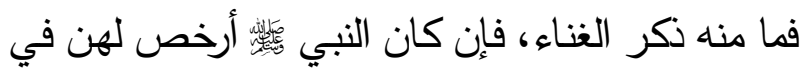
ذللك، فليس منه ما يوجب المدح في حق عقلاء الرجال

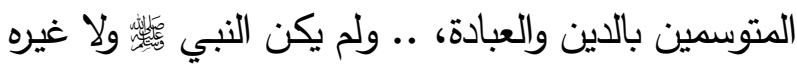

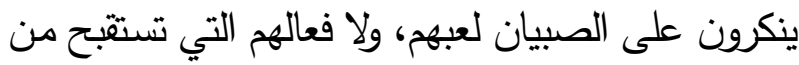
غيرهم، مثل المصافحة، والمفاقسة (')، بالبيض الأحمر ،

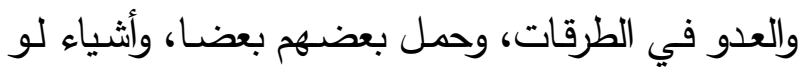

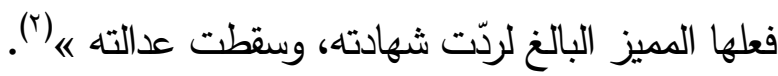

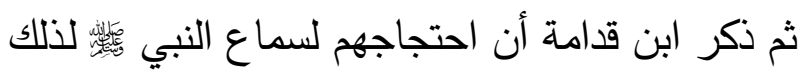

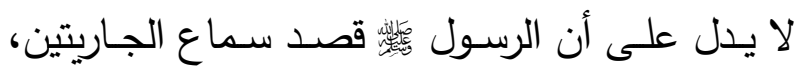

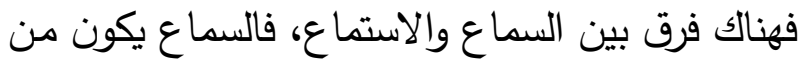

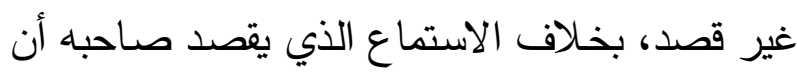

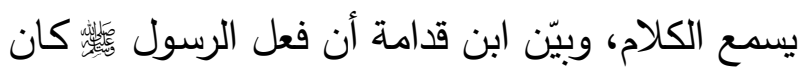

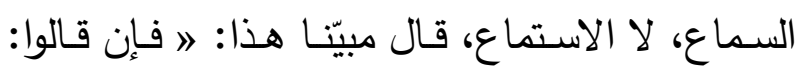

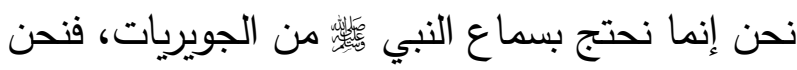

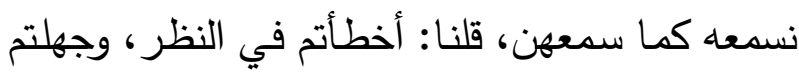

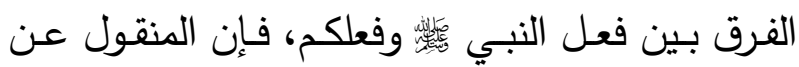

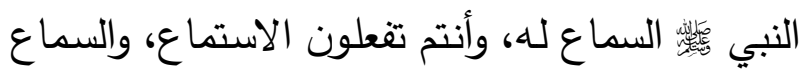
غير الاستماع «") ومما يعضد ذلك أن النبي النيّة عندما سمع الجاريتين ( (1) المفاقسة بالبيض، مأخوذ من فَقَس البيضـة يَفْقسـها إذا فضـخها. انظر : (1) لسان العرب ( • (1/ • (ب).

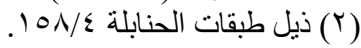

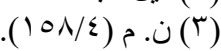


المحـدثين، وإنمــا هـي أحاديــث مروجــة وأكاذيـبـ

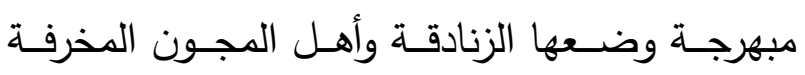
يرمسون بـذلك نسـبة اللهـو والمجـون إلـى الأنبيـاء

$$
\text { الفضلاء « (०). }
$$

قال أحمد الأذرعي (ت بی Vه): 》 وأطال القرطبي

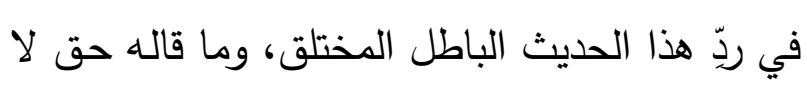

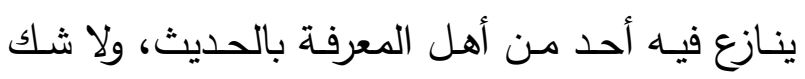
فيه، فالله حسيب مفتريـ « (؟). وقال ابن القيم رحمه الله عن حديث تواجد رسول الله

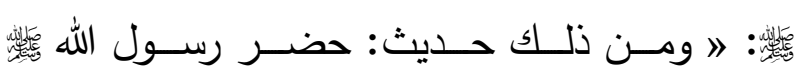
سماعًا، ورقص حتى شق قميصه، فلعن الله واضعه،

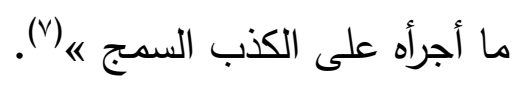
وقال رحمه الله في موضـع آخر عن هذا الحديث:

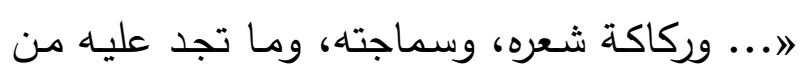

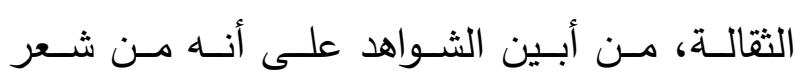

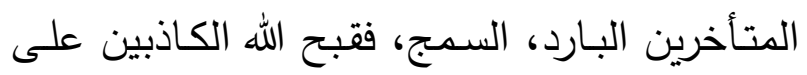
رسول الله أيضًا قال الشاطبي (ت • لو هـ) رحمه الله عن حديث التواجد: " فمنهـا اعتمـادهم على الأحاديـث الواهيـة

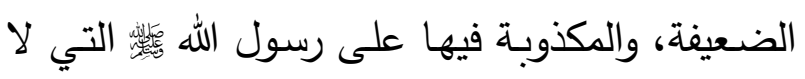
يقبلهــا أهـل صــناعة الحـديث فـي البنــاء عليهـا

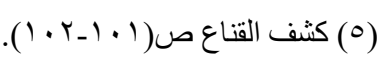

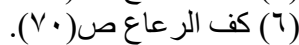

المنار المنيف في الصحيح و الضعيف، لابن القيم، تحقيق عبدالرحمن (V)

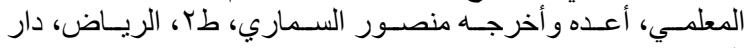

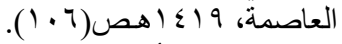

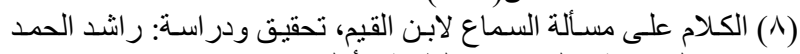

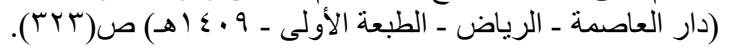

أخـذ العلـم عنهـا، وتـأدب بهـا، فبطل مـا قالـه هـذا القائل) (') (1) وعدّ الطرطوشـي رحمـه الله مـا يفعله المتصـوفة عند الســـاع مـن الـرقص والطـرب وتمزيـق الثيـاب مـن ولـ السخافة وانعدام المروءة والوقار قائلا: 》 وأما الرقص والدقّ (r)، وكشـف الرأس وتمزيـق الثياب فـلا خفـاء على ذي لب أنه سخف ولعب ونبذ للمروءة والوقار ولما كان عليه الأنبياء والصالحون «(r). وقد ردَّ أبوالعبـاس القرطبي على الصـوفية استدلالهه

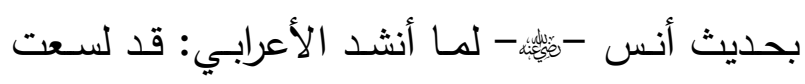
حية الهوى كبدي..... فقال إن الحديث لا يصح لإن محمد بن طاهر المقدسي، لا يحتج بحديثه؛ لأنـه قد تُكَلمِ فيـه ونسب إلى مذهب الإباضية وعنده مناكير في كتابـه المسيء " صفة أهل التصـوف «، وهذا الحديث منها:

وقال: 》 إن الواقف على متن هذا الحديث يعلم على

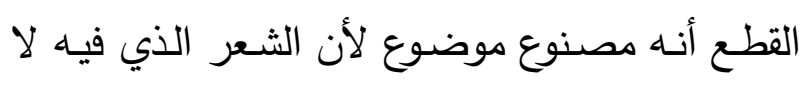
يناســب شـعر العـرب، ولا يليـق بجزالـة شـعرهم ولا لا ألفاظهم وإنما يليق بمخنثي شعر المولدين «(ء).

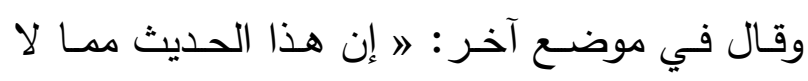

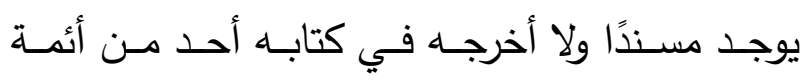

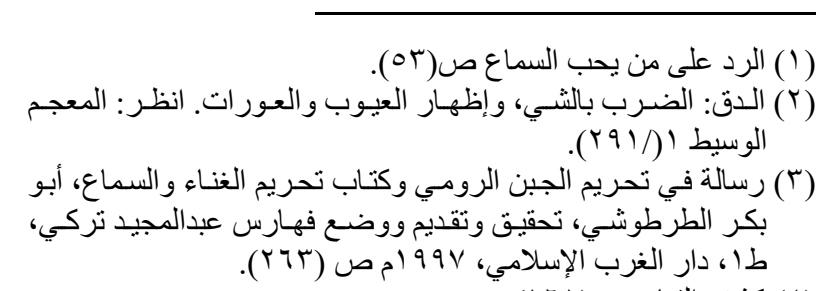

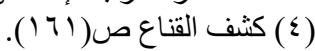


الصــفوة ه ورواه مــن طريقـــه أبــوحفص عمــر السهروردي صاحب 》 عوارف المعارف «، أن النبي  قد لسعت حية الهوى كبدي..... الأبيات وأنه تواجد حتى سقطت البردة عن منكبيه، فقال لـه

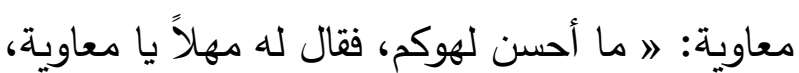
ليس بكريم من لم يتواجد عند ذكر الحبيب «.

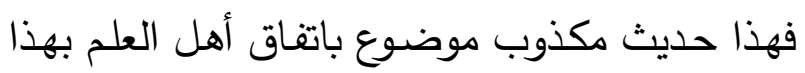

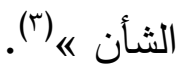

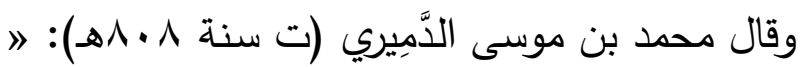

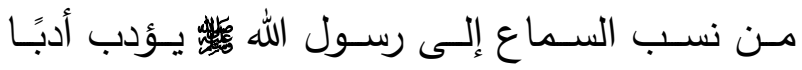

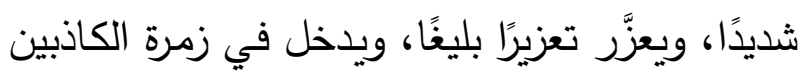

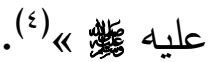
وعذّ أحمد الأذرعي هؤلاء المتفقرة ومن حذا حذوهم مـن المتفقهـه -ويقصــ في ذلك المتصـوفة-؛ مـن المتوهمين، المغرمين بالرقص، وما يقومون به خطأ فئه

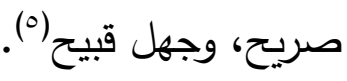
ولقد شبّه الطرطوشـي الصـوفية بينـي إسـرائيل، عندما اتخذذوا عجـلا آلهـة للعبـادة دون الله، وقيـامهم بـالرقص

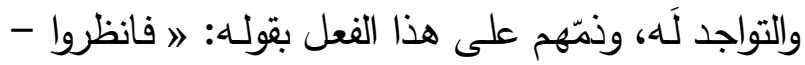
رحمكم الله!- كيف يجوز على نبي من أنبياء الله أن يتخذ عجلا للعبادة من دون الله تعالى ثم يرقص هو وهم

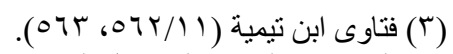

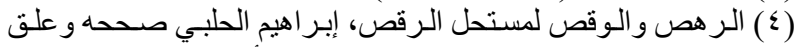

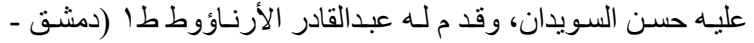

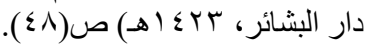

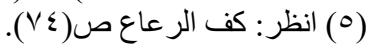

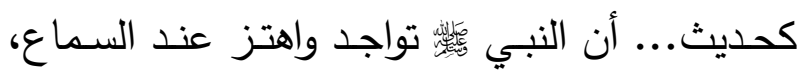
حتى سقط الرداء عن منكبيه، وما أشبه ذلك، فإن

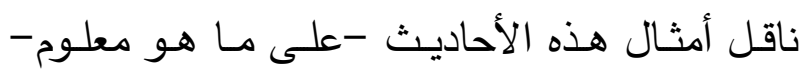

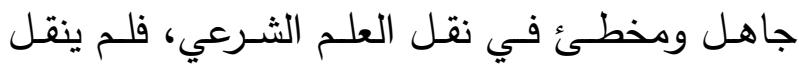
الأخذ بشيء منها عمن يعتد به، في طريق العلم، ولا طريق السلوك «" (') ونقل الحافظ ابن حجر رحمـه الله في فتح الباري في معرض إنكاره للسـماع الصـوفي، قول القرطبي: "

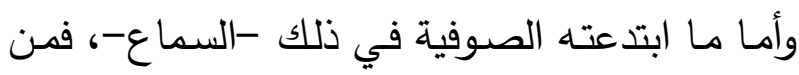
قبيل ما لا يُختلف في تحريمه، لكن النفوس الشهوانية غلبت على كثير ممن ينسب إلى الخير ، حتى لقد

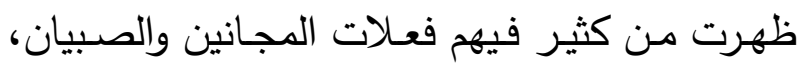
حتى رقصوا بحركات متطابقة، وتقطيعات متلاحقة،

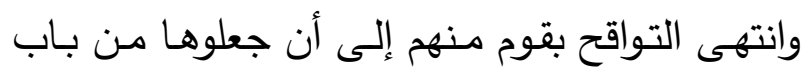

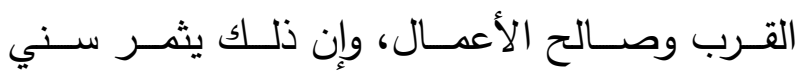
الأحوال. وهذا على التحقيق: من آثار الزندقة وقول أهل المخرقة، والله المستعان «آ (r).

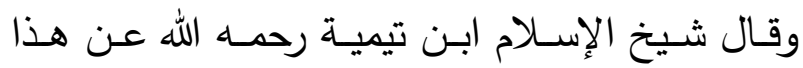

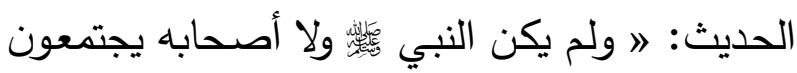
على مثل هذا السماع ولا حضروه قط، ومن قال أن أن

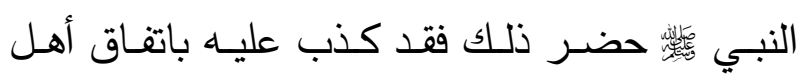
المعرفة بحديثه وسنته. والحديث الذي ذكره محمد بن طاهر المقدسي في " مسألة السماع " وفي " صفوة

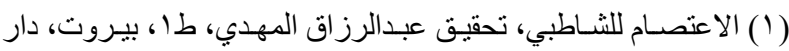

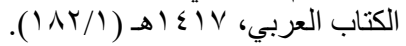

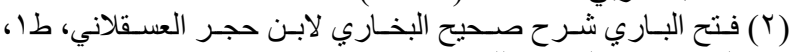

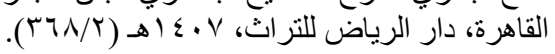


السماع مستحب لهم لحياة قلوبهم. قال هذا غلط من

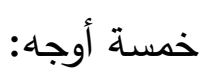

أحدها: أن أبا حامد الغزالي قال بإباحة سماعه لكل أحد. وأبوحامد أعرف من القشيري الذي روى ذلك. الثاني: أن طباع النفوس لا تتغير وإنمـا المجاهدة تكف عملها. فمن ادّعى تغير الطباع ادّعى المحال. فإذا جاء ما يحرك الطباع. واندفع الذي كان يكفها

$$
\text { عنه عادت العادة. }
$$

الثالث: أن العلماء اختلفوا في تحريمه وإباحته وليس فيهم من نظر في السامع لعلمهم أن الطباع تتساوى،

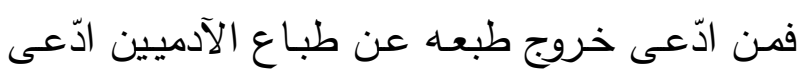

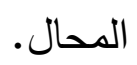
الرابع: أن الإجماع انعقد على أنه ليس بمستحب،

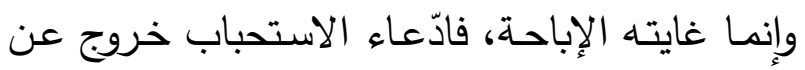
الإجماع. الخامس: أنه يلزم من هذا أن يكون سماع العود مباحا أو

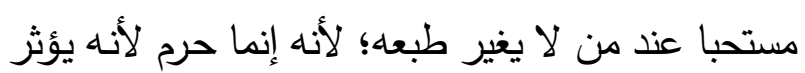

$$
\text { في الطباع ويدعوها إلى الهوى «ـ (o). }
$$

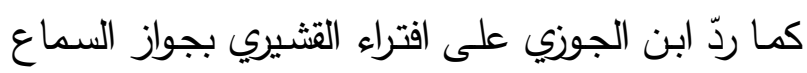

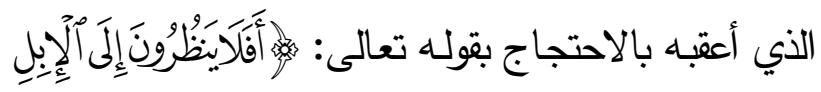

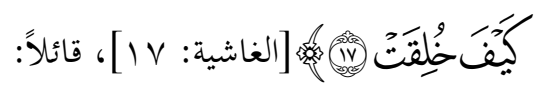
هذه الآيـة لا تدل على الغناء ولا على الرقص ولا

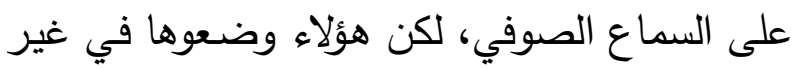
مواضعها، وحادوا بها عن سواء السبيل.
تعظيما للعجل على أنه إلاههم؛، فما أثبه عقول قوم قد جعلوا الرقص عبادة لله تعالى بعقول بني إسـرائيل في إلهاي

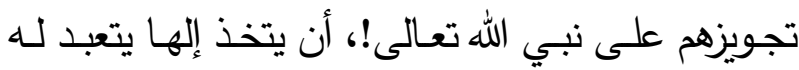

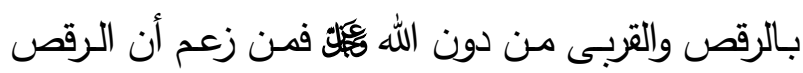
عبادة لله سبحانه! يرقصون بين يديه ويتواجدون له فإلهه دونه عجل، جسد له خوار « (') وهذا أبوالوفاء ابن عقيل (ت ب إ0ه) رحمه الله، الذي

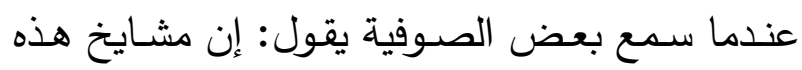
الطائفة كلمـا وقفت طباعها حداها الحـادي إلى الله بالأناشيد، ردّ عليه بقوله: " لا كرامة لهذا القائل إنما

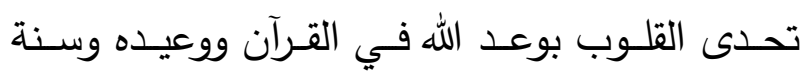
الرسـول

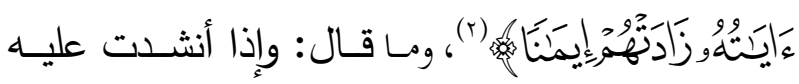
القصائد طربت. فأمـا تحريك الطباع بالألحان فقاطع

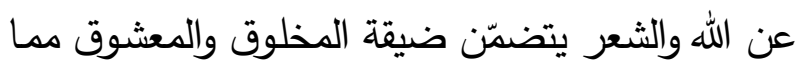

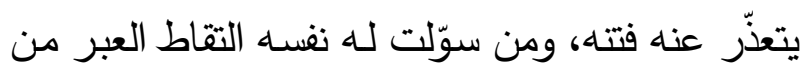

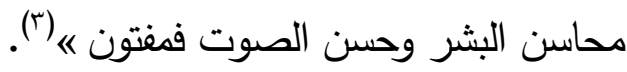
وكّّر ابن عقيل من يعتقد أن الدعاء وقت السماع

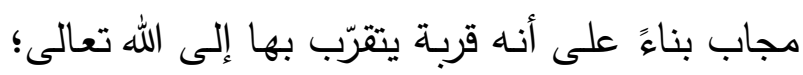

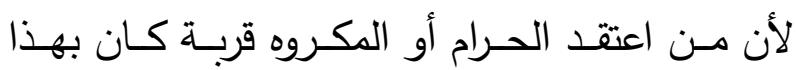
الاعتقاد كافرا «(๕). وردّ ابـن الجـوزي على الصــوفية، عندما زعمـوا أن

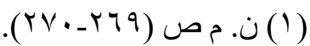
(Y) (Y) (Y) (Y) مرة الأنفال، آية (Y) (Y) (Y) (Y)

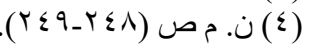




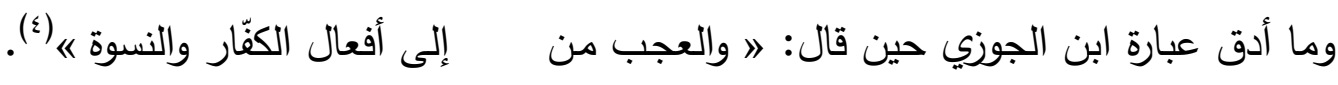
كما عدّ القاضي عياض قسم من الصسوفية؛ جهلة، ورعهم في الطعام وانبساطهم في القرآن «" ('). وذلك عندما استحوذ عليهم الثيطان، وغلب عليهم

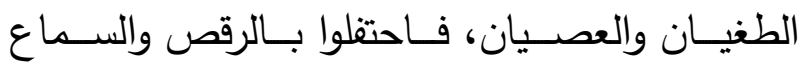
والثهوات التي تثيرها الطباع، لا يقتفون بذلك شرعا لـان

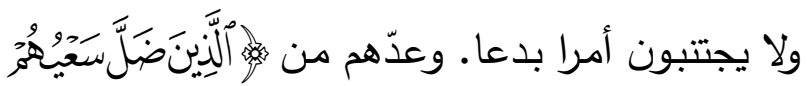

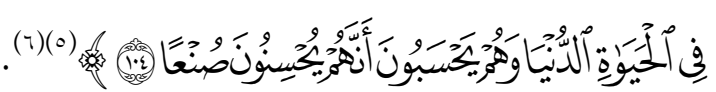
كما أنكر القاضي عياض رحمـه الله على الصـوفية

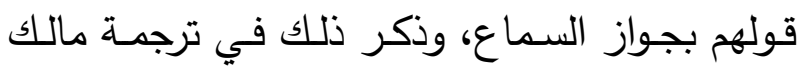

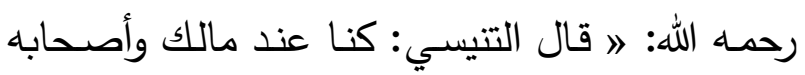
حوله، فقال رجل من أهل نصيبين (v): عندنا قوم يقال لهم الصوفية، يأكلون كثيرا، ثم يأخذون في القصائد،

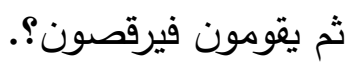
وقال مالك: أصبيان هم؟ قال: لا، قال: أمجانين هر؟

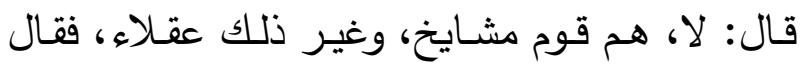

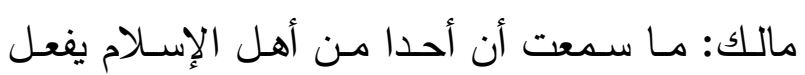
هذا! «) مأنا: وعندما استفتي الثيخ أبوإلياس محمد بـن الحسين

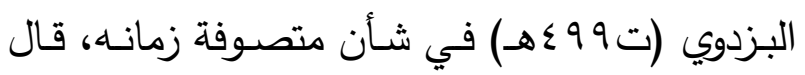

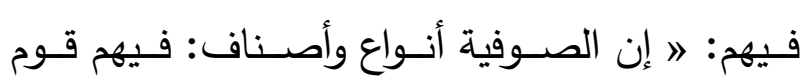

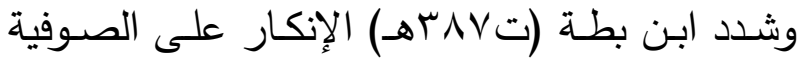

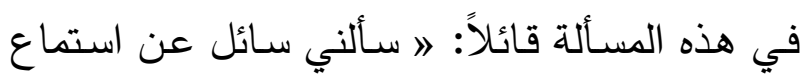

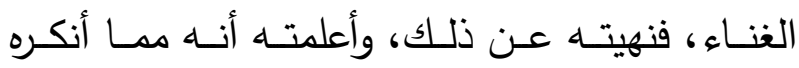

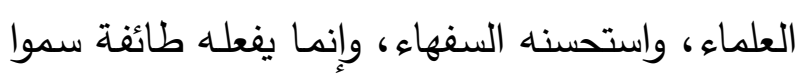

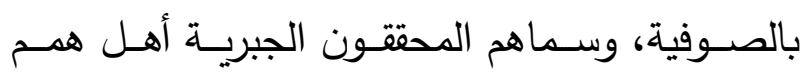

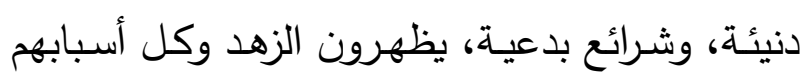

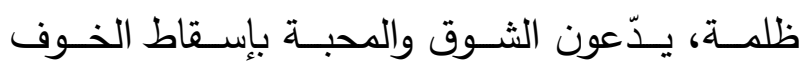

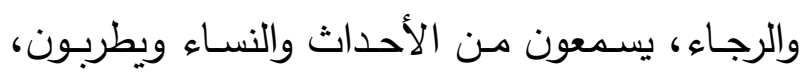

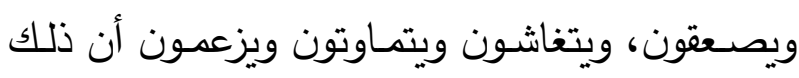

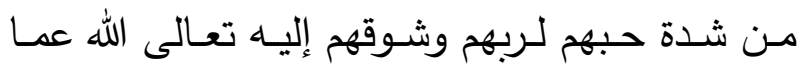
يقولون علوّا كبيراً « (r).

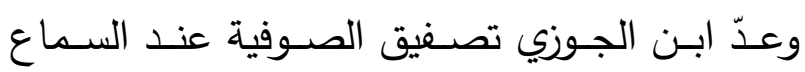

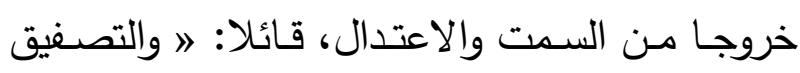

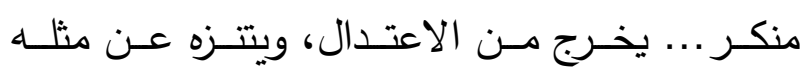
العقلاء، ويتشبه فاعله بالمشركين، فيما كانوا يفعلونـه

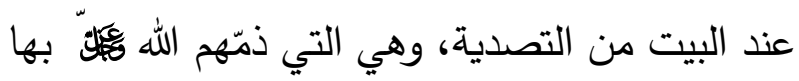

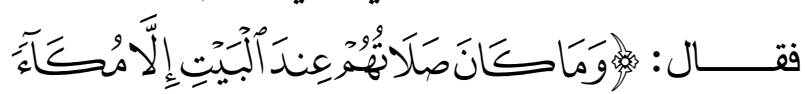

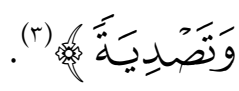
فالمكاء: الصفير ، والتصدية: التصفيق... ومنه أيضا تشبّه بالنساء، والعاقل يأنف من أن يخرج من الوقار 
وعندما احتجّ جهّال الصـوفية على جـواز طـربهم

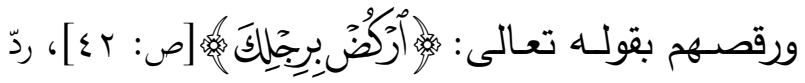

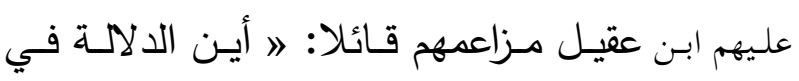

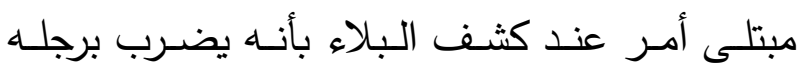

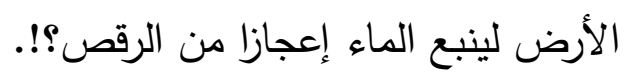

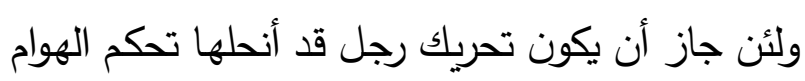

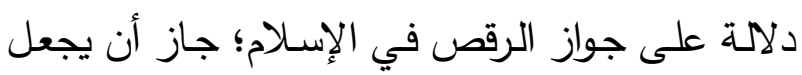

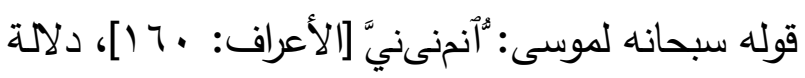

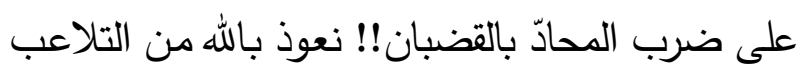

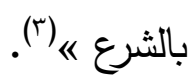

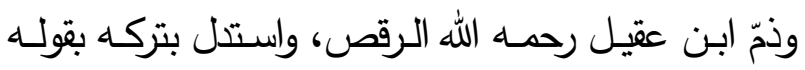

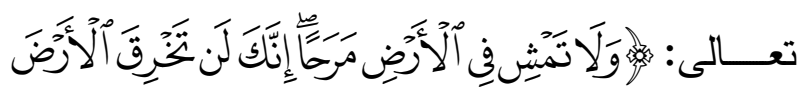

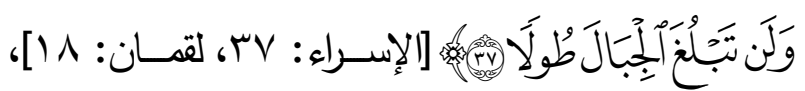

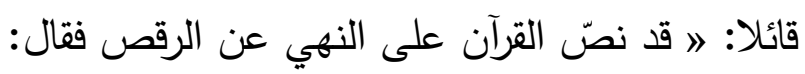

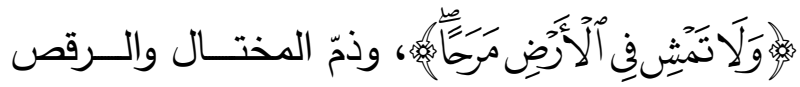

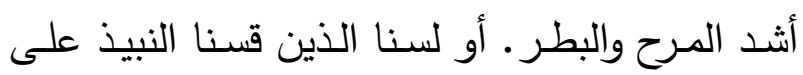

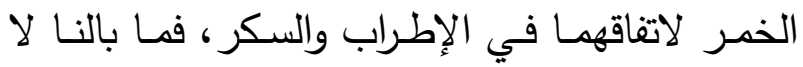
نقيس القضيب وتلحين الثـعر معسه على الطنبور والمزمار والطبل لاجتماعهما.

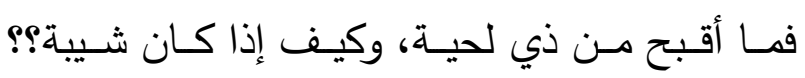

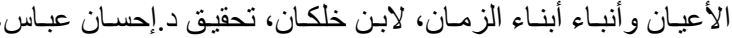

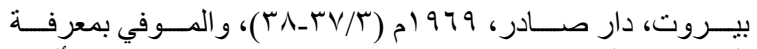
التصـوف والصـوفي ص (ب (، ع 1)، مـع اختلاف يسير في الألفـاظ فيما بين هذه المصادر .

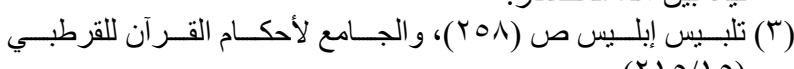

يضربون بالمزامير ، ويشربون الخمور ويأتون بعض

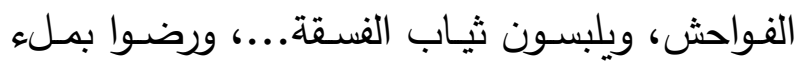

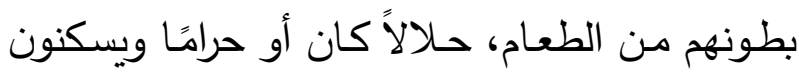

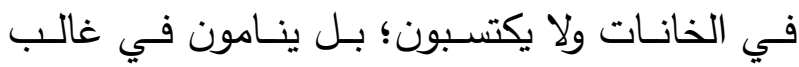

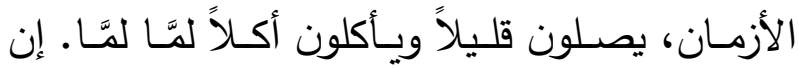

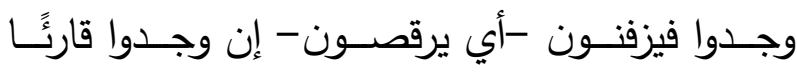
فاختاروا الكسل ولا يتعلمون ولا يتزوجون «" ('). وما أحسن إنكار ظهير الدين الموصلي (ت • (7هـــ

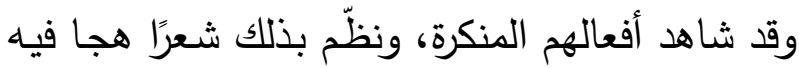

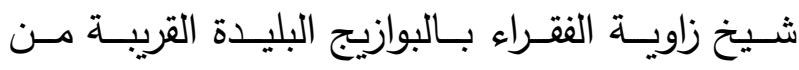
السلاَّمية، قال فيه: ألا قل لهم قول عبد نصوح وحق النصيحـة أن تستمع

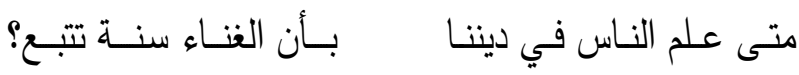

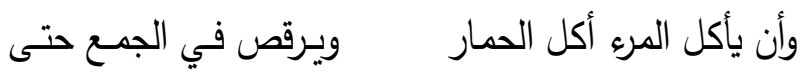

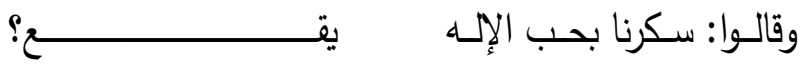

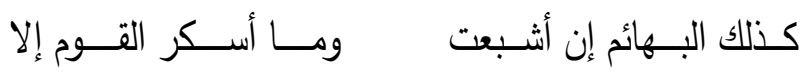

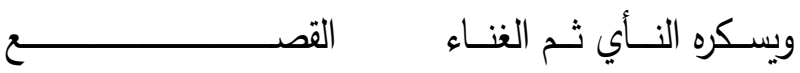

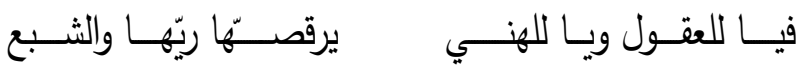
ويس لـو تليت ما انصدع

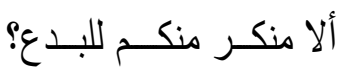

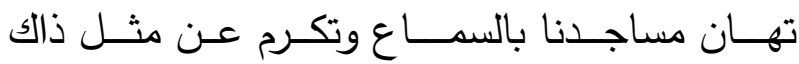
البيع (r)

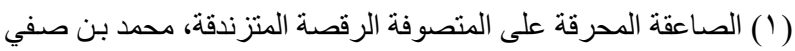

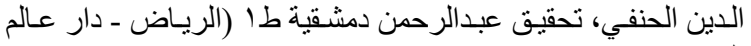

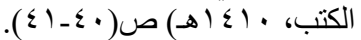

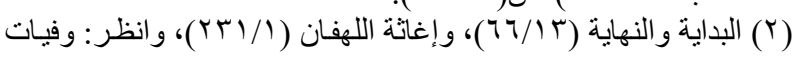


غلبات الطباع والأهواء، وهل يحكم على العقول حق قط؟ وهـل رأيـتم في السـلف أو ســعتم رجـلاً زعـق أو خرق؟ بل سماع صسوت وفهم واستجابة، فدلَّ على أن ذلك التخبط ليس من قانون الشـرع، لكن أمر بخفض الصوت وغضِّه، وأمسا التواجد والحركة والتخريق فالأشبه بداعية الحق الخمود، ثكلت نفسي حين أسمع القرآن ولا أخشع؛ وأسمع كلام الطرقيين فيظهر مني الانزعاجه (ء). وعزا ابن الجوزي ذلك التواجد المفضـي إلى تخريق الثياب والصياح إلى تمكّن الشيطان في عقول هؤلاء الجهلة، فقال: \ وهذا التواجد الذي تضدن حركات المتواجدين وقوة صسياحهم، وتخبطهم، فظـاهره أنـه متعمّل، والشيطان معين عليـه. فإن قيل: فهل في حق المخلص نقص بهذه الحالة الطارئة عليه؟ قيل:

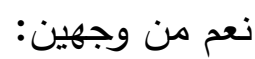
أحدهما: أنه لو قوي العلم؛ أمسك. والثاني: أنـه قد خولف بـه طريق الصـحابة والتابعين، ويكفي هذا نقصا «) ويقول أبوالعباس القرطبي وهو يتهكم على الصوفية وجـدهم: \ا التواجـد: اسـتـعاء الوجـد، لضـربٍ مـن الاختيـار ؛ وذلـك أنهـم إذا اجتمعـوا للسـماع، فمـنهم المتكلف حركة ظاهرة، مستجلبًا بذلك حضور باطنه؛

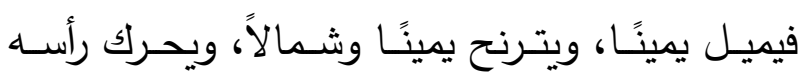

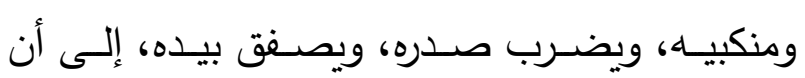

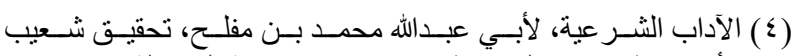

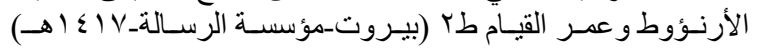

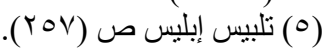

يـرقص ويصـفق على إيقـاع الألحسان والقضــبان وخصوصا إن كانت أصوات النسوان ومردان، وهل الإن يحسـن لمـن بـين يديـهـ المـوت والســؤال والحشـر والصـراط، ثـم هـو إلـى إحـدى الـدارين يثـمس (1) بالرقص، شمس البهائم، ويصـق تصفيق النسـوان، والله لقد رأيت مشايخ في عمري ما بان لهم سن من لن

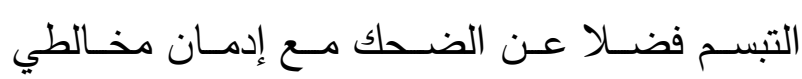

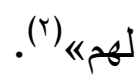

ولما سئل ابن عقيل عن تواجد الصوفية، وتخريقهم ثيـابهم، أنكر ذلـك أشـدّ الإنكـار ، وعدّه مـن الخطـأ

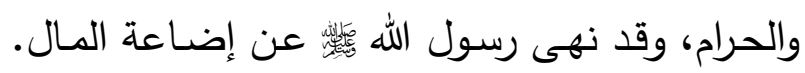
فقال لـه قائل: فإنهح لا يعقلون ما يفعلون. فقال: إن

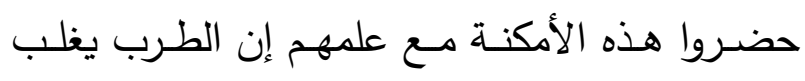
عليهم، فيزل عقولهم، أثموا بما أدخلوه على أنفسهم من التخريق وغيره مما يفسد ولا يسقط عنهم خطاب الشـرع، لأنهم مخـاطبون قبـل الحضـور بتجنّب هذا الموضوع الذي يفضي إلى ذلك، كما هم منهيون عن لـن شرب المسكر ، كذلك هذا الطرب الذي يسميه أهل التصـوّف وجدا إن صـدقوا إن فيـه سـكر طبـع، وإن كذبوا أفسدوا مع الصحو، فلا سلامة فيه مع الحالين، وتجنّب مواضع الريب واجب «(). وشدد ابن عقيل رحمه الله الإنكار على الصوفية في هذه

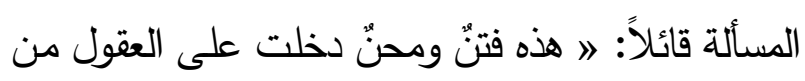

(1) شمست الدابـة شموسـا، وشماسـا: جمحت ونفرت. انظر المعجم الوسيط

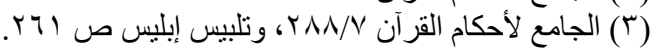


إذا اشـتـ طـربهم على المغني. ثم مـنهم مسن يرمي بها صحاحا، ومنهم من يخرقها ثم يرمي بها. قال هؤلاء في غيية فلا يلامون، فإن موسى عليه السلام لما غلب عليه الغم بعبادة قومه العجل رمى الألواح فكسّرها ولم يدر ما صنع

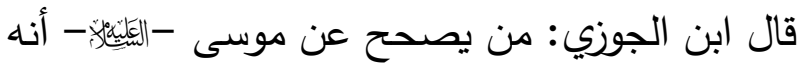
رماها رمي كاسر؟ والذي ذكر في القرآن ألقاها. فمن أين لنا أنها تكسرت؟ ثم لو قيل: تكسّرت فمن أين لنا أنها قصد كسرها؟ ثم لو صححنا ذلك عنه قلنا كان في غيبة حتى لو كان بين يديه بحر من نار لخاضاه ومن يصحح لهؤلاء غيبتهم وهم يعرفون المغني من غيره، ويحذّرون من بئر لو كانت عندهم، ثم كيف تقاس أحوال الأنبياء على أحوال هؤلاء السفهاء «(ّ).

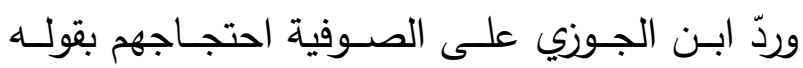

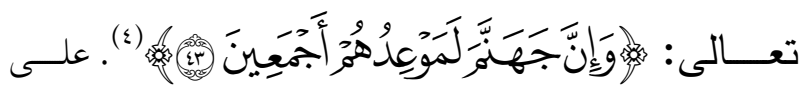

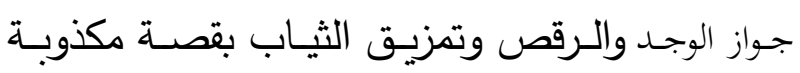
على سلمان الفارسي على أنـه عندما سمعها صـاح صيحة ووقع على رأسـا ثم خرج هاربـا ثلاثة أيّام (ْ). فردَّ ذلك الاحتجاج من وجوه: الأول: أن هذا محال وكذب. الثاني: ليس لذلك إسناد. الثالث: الآية نزلت بمكة وسلمان أسلم بالمدينة. الرابـع: لـم ينقـل عـن أحـــــــ الصـحابة مثل هـــا
يسـتغرقه -بزعمـهـ- الوجد....، وهـذه أفعـال مليحـة، واجتماعـات ذميمـة، وأحسوال صـادرة عـن اعتقــادات سقيمة، فما هي إلا أحوال دحيضـة، وعقول مريضـة، ودعوى عريضـة، وبذلك على مـا ذكرنـاه: أن رسول

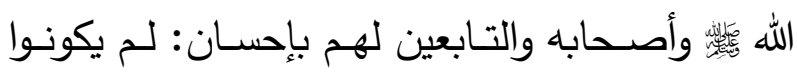
على شيء من تلك الأساليب والطرائق، ...ولا نطقوا بتلك العبارات، ولا ارتضوا تلك الإشارات، ولا اجتمعوا لذلك، ولا حوَّموا على شيء عمـا هنالك، مـع أنهم قدوة العارفين، وخيرة الله من العالمين، الفاهمون عن

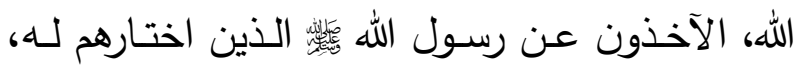
لحمل أمانته، وبيان شريعته، فلو كان الأمر على ما اخترعـه أصــحاب التواجـد، لكـان أولئك المـلأ، أوّل سـابق إليـه، وأول واجـد، وتتـاطقوا بتلـك العبـارات، وأثـاروا بتلك الإشـارات، ولفثـا ذلـك في السـابقين المتشرعين، كما فشـا في المتأخرين المبتدعين، فلما لم يكن شيء من ذلك، علمنا أنه من المحدثات التي هي بدع وضلالات.... «"). وعندما احتج الصوفية على رميهم الثياب وتمزيقها بقوله

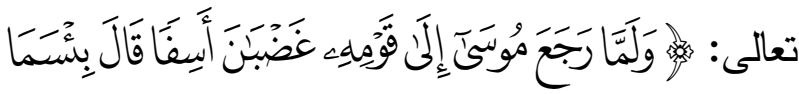

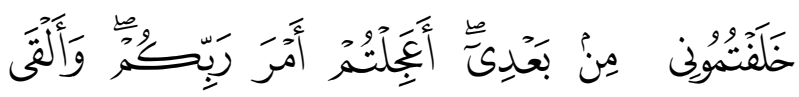

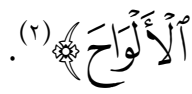
ردَّ ابـن الجـوزي علـيهم احتجـاجهم قـائلاً: 》ا اسـتل بعض جهّال المتصوّفة بهذه الآية على جواز رمي الثياب 
هو حرام، خصوصًا في هذا الزمان الذي اشتهر فيه الفسق، وظهرت فيه أنواع البدع، واشتهرت فيه هانه طائفة تحلَّوا بحلية العلماء، وتزيّنوا بزي العلماء، والحال أن أن قلوبهم ملئت من الثهوات الفاسدة، وهم في الحقيقة ذئاب، نعوذ بالله من شرهم «" (๕).

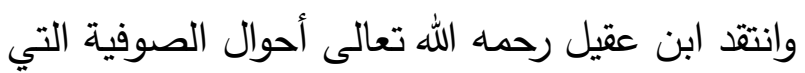

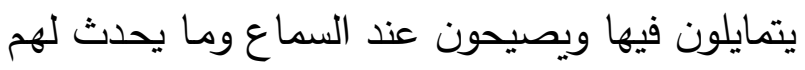
من صسق وغشيان، وحكم عليهم بالتعزير ، قائلا:

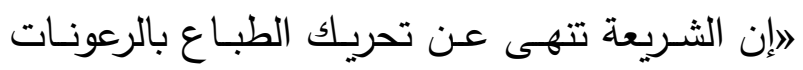
وتمنع دق الطبول، ونهت عن الندب والنياحة والمرح

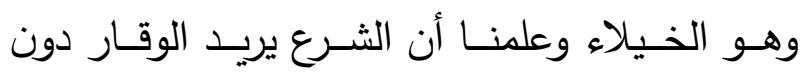

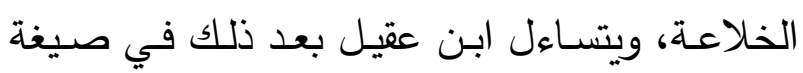

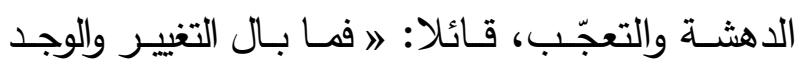
وتخريق الثياب والصعق والتماوت مـع هؤلاء المتصوفة؟ لهاب

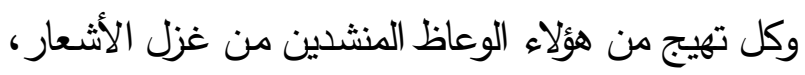
وذكر الفسّاق، فهم كالمغني والنائح، فيجب تعزيرهم؛ لأنهح يهيجون الطباعه (0) وردَّ الطرطوشـي على الصـوفية الاسـتـلال بالقيـاس

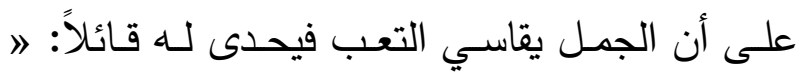

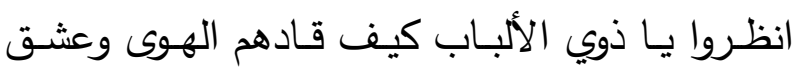
الباطل وقلة الحيلة إلى هذه السخافة، وحسبك من البن

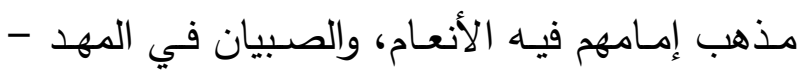

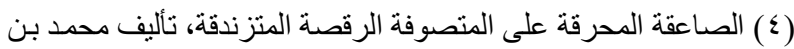

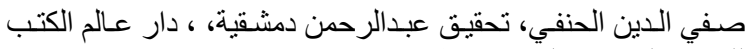

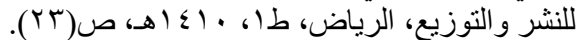

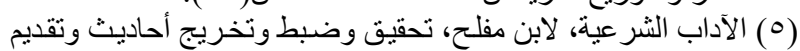

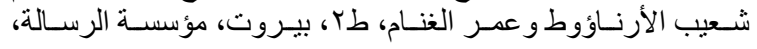
(r.V/T) ( $61 \leq 1 \mathrm{~V}$

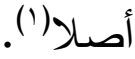
وقـال سـلطان العلمـاء الثـيخ عزالـدين بـن عبدالسـلام

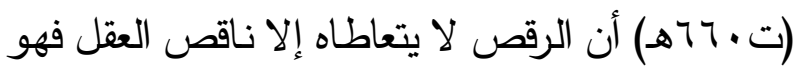

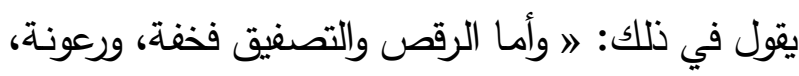

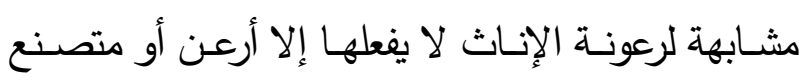

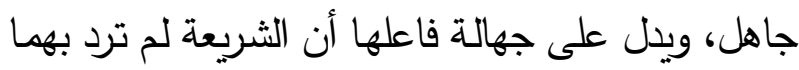
لا في كتاب ولا في سنة ولا فعل ذلك أحد من الأنبياء ولا معتبر من أتباع الأنبياء وإنما يفعله الجهلة السفهاء النين

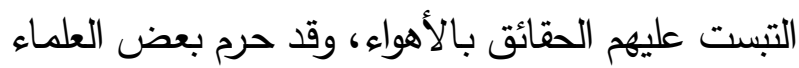

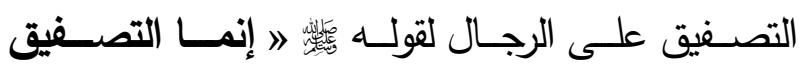
لإنساء وقال رحمـه الله عن صياح الصـوفية أثناء السماع: اوقد يصيح بعضهم لغلبة الحال عليه وإلجائها إياه

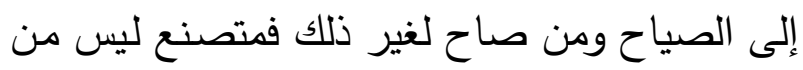
القوم في شيء، وكذا من أظهر شينًا من القوم رياءً

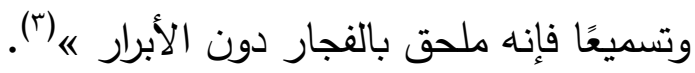

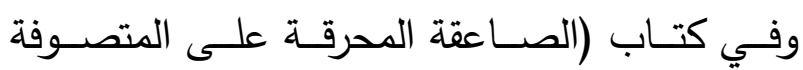
الرقصة المتزندقة) نقل محمد بن صفي الدين الحنفي

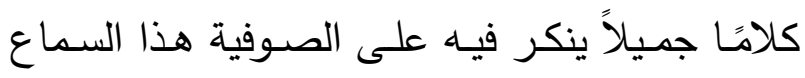
جاء فيه: " ويجب منع الصوفية الذين يدَّعون الوجد هيد

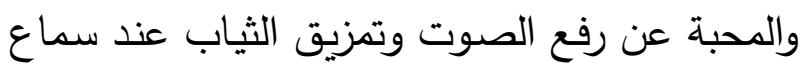
الغناء، لأن ذلك -أي رفع الصوت وتمزيق الثيابحرام عند سماع القرآن فكيف عند سماع الغناء الذي لان دئ

$$
\text { (1) (1) انظر : تلبيس إبليس ص (Y01) (1) (1) }
$$

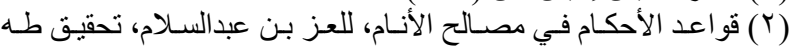

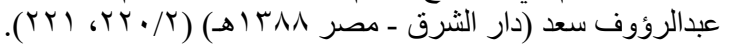

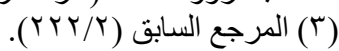


قلوبهم بما لا ترق عند القرآن، ومـا ذالك إلا لتمكّن

هوى باطن، وغلبة طبع وهم يظنون غير هذا «().

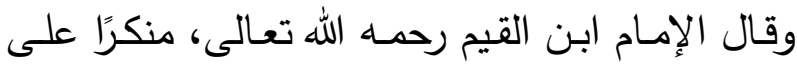
الصوفية الذين آثروا السماع على قراءة القرآن:

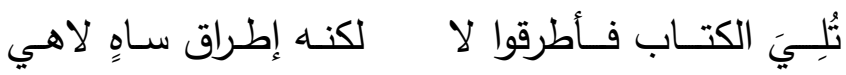
والله مــا رقصـــوا لأجـل خيف

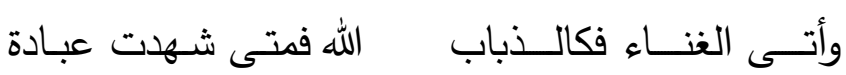
بمرلا lo

تقييـده بـأوامر ونــواهي دفتُ ومزمـار ونغمـة شـاهد إطلاقـهـ في اللهـو دون ثَقُقل الكتاب عليهم لما رأوا اهي وعليهم حسنَّ الغنـاء لمـا رأوا يـا فرقـة مـا ضـر دين وجنـى عليـهـ وملــه إلا

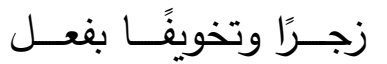
سـمعوا لـه رعـدًا وبرقًا إذ اهي

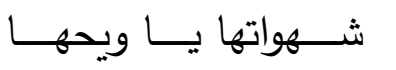

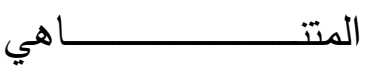
فلأجـل ذاك غدا عظيم se ورأوه أعظـم قـاطع للـنفس عـــــــ وأتــــى الســـماع موافقَّــا الج ه

$$
6
$$
أغراضد

إن لم يكن خمر الجسـوم خمـر العقـول مماثـل

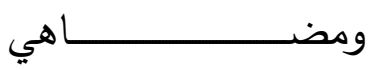
فـانظر إلىى النشـوان عندـ وانظر إلى النشوان عند

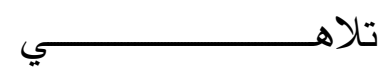
مـن بعـد تمزيـق الفـؤاد

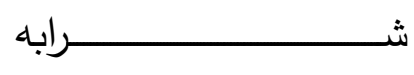

وانظـــر إلــى تمزيـــق ذا يقصـد بـذلك الغزالي - وهكذا يفضـح الله تعـالى مـن اتبـع الباطل، وحسبك مـن عقول لا تقتدي بأخبـار المسلمين وعلمائهم وتقتدي بالإبل، فإن كان كل ما طربت له البهائم مندوبًا او مباحًا، فإننا نرى البهيمة تتزو على أمها وأختها وتركب بنتها، أفيلزم الاقتداء بالبهيمة في مثل هذا «('). كما بيَّن علي بن أبي العز (ت مبولهو) في الطحاوية، أن الصعق لم يكن من صفات السلف بلف الصالح، ولو عند سماع القرآن، فقال في معرض ردَّه على الصوفية: 》 وكذلك الذين يصعقون عند سماع الأنغام الحسنة، مبتداعون ضالون، وليس للإنسان أن يستدعي ما يكون سبب زوال عقله، ولم يكن في الصحابة والتابعين من يفعل ذلك، ولو عند سماع القرآن، بل كانوا كما وصفهم الله تعالى : إنََّّا

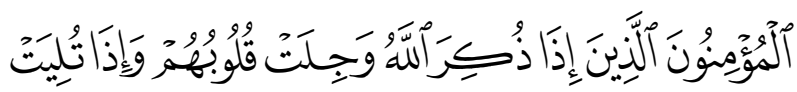

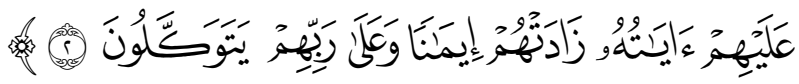
. (الأنفال: وعنـدما آثـر الصـوفية السـماع على قـراءة القـرآن؛ لـزعمهم أنـه أكثر رقـة للقـوب منـه؛ عـزا ذلك ابـن الجـوزي إلى ميـل هـؤلاء القـوم إلى الهـوى وإشـباع الرغبـة بمـا هو باطلـ، فقـال: 》 وقـد نشـب السـماع بقلوب خلق منهم، فآثروه على قراءة القرآن، ورقت

(1) ) رسالة في تحريم الجبن الرومي وكتاب تحريم الغناء و السماع، أبو

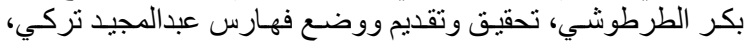

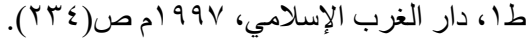

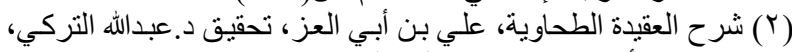

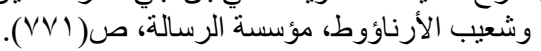


أصحابه والتابعين لهم بإحسان «(「). وقد بين ابن تيمية رحمه الله خطأ من دعا الله باسمه لهابه

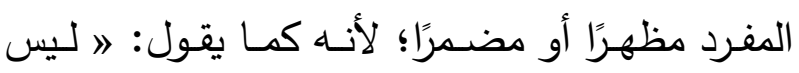
بكلام تام ولا جملة مفيدة ولا يتعلق به إيمان ولا كفر ولا أمر ولا نهي، ولم يذكر ذلك أحد من سلف الأمسة ولا شرع ذلك رسول الله ولا يعطي القلب بنفسه معرفة دمة دهن

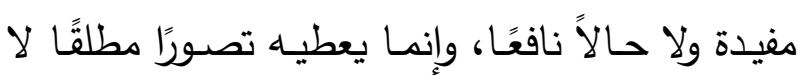

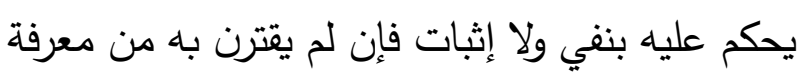

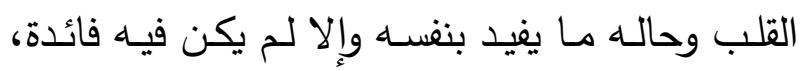

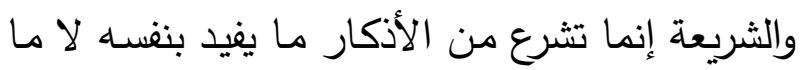
تكون الفائدة حاصلة بغيره ه( (؛).

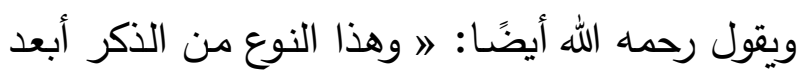

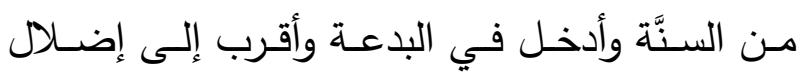

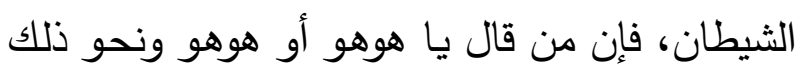

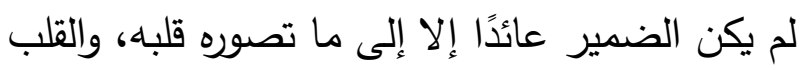
قد يهتدي وقد يضل «ان إن. قلت: والمشـروع من ذكر الله هو ذكره بجملـة تامـة لهـ

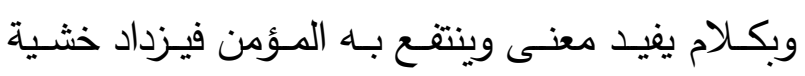
ومحبة ومعرفة بربـه، أمسا الاقتصار على الاسم المفرد

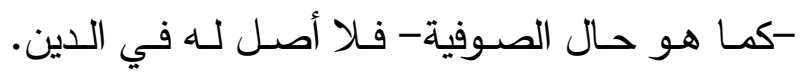

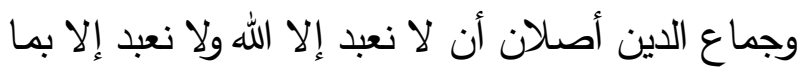

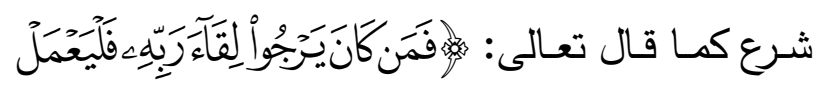

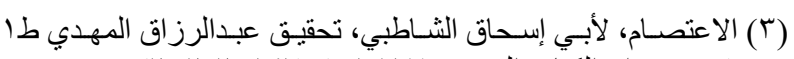

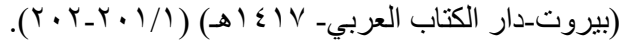

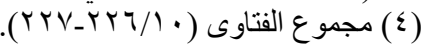

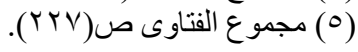

اللاهـ

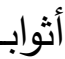

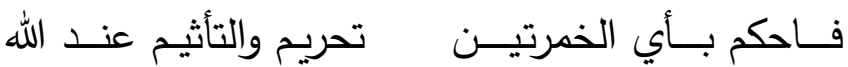

وتوعَّدـ ابـن كثير رحمـه الله هـؤلاء الـذين لا يتأثرون

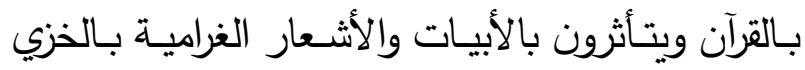

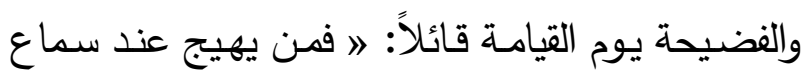

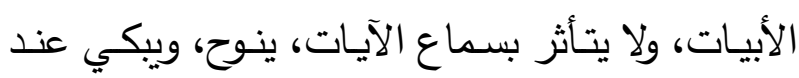

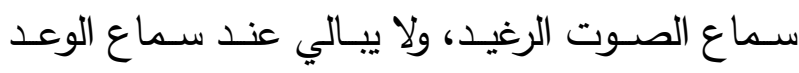

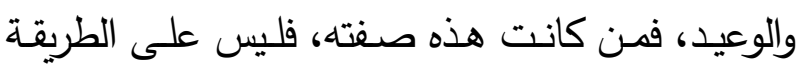
الصـحيحة، بـل هـو مـن الذين إن لـم يتوبـوا ويقلعـوا:

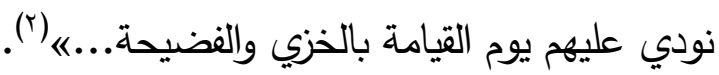
- الرد على بلدعة الأكر عند الصوفية:

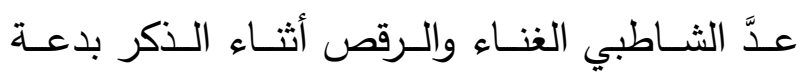

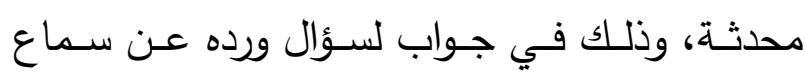

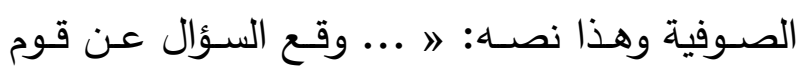

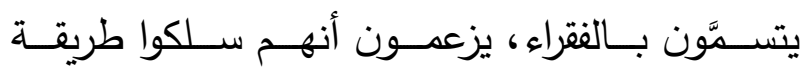

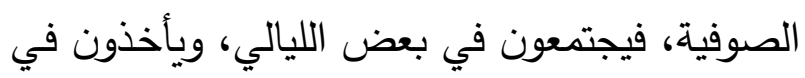
الذكر الجهوري على صـوت واحد، ثم في الغناء والرقص، إلى آخر الليل....، هل هذا العمل صحيح في الشرع أم لا؟ فأجاب الشاطبي رحمه الله: 》 بأن ذلك كله من البدع لاع

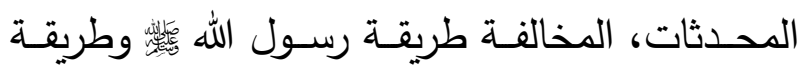

\footnotetext{
(1 ) مدارج السالكين، لابن القيم، تحقيق محمد حامد الفقي، بيروت، دار

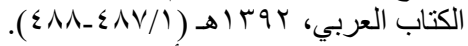
(ץ) جواب لابن كثير عن مسألة السماع، بذيل كتاب الكلام على مسألة

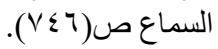




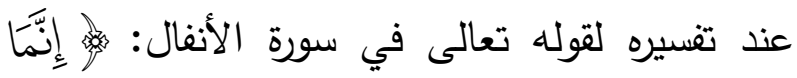

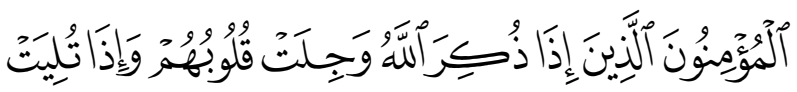

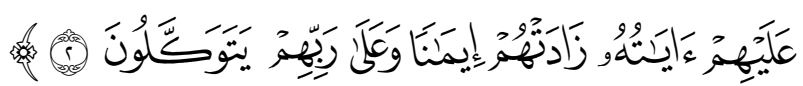

[الأنفال: r [ب]

قال رمه الله: 》ا وصف الله تعالى المؤمين في هذه الآية بالخوف والوجل

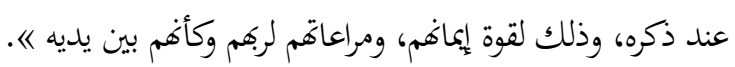

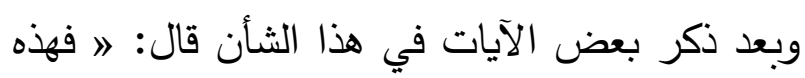
حالة العارفين بالله، الخائفين من سطوته وعقوبته، لا لا فئل

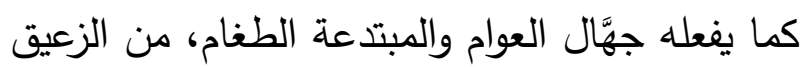
والزئير -أي الصياح- ومن النهاق الذي يشبه نهاق

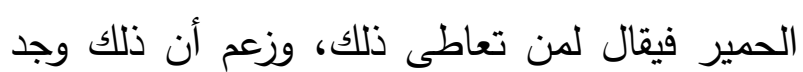

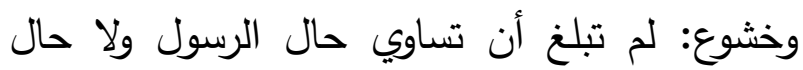

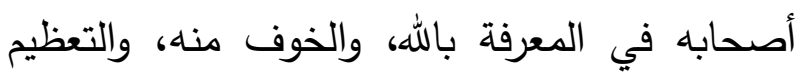
بجلاله، ومع ذلك فكانت حالهم عند المواعظ: الفهر عن الله، والبكاء خوفًا من الله ولذلك وصف الله الله أحوال أهل المعرفة عند سماع ذكره وتلاوة كتابه

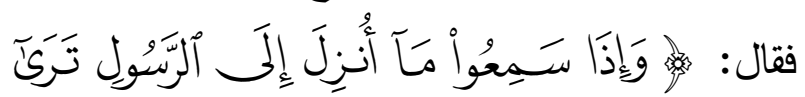

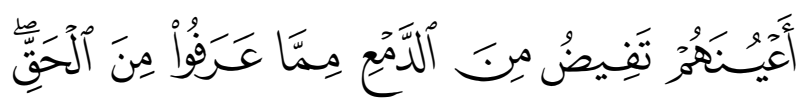

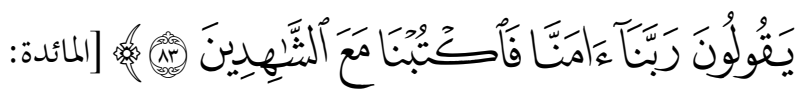
. [^r

فهذا وصف حالهم، وحكاية مقالهم. ومن لم يكن كذلك فليس على هديهم، ولا على طريتهم. فمن كان مستتًا

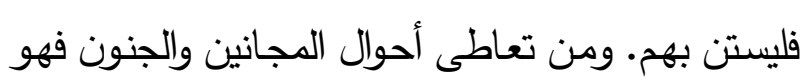

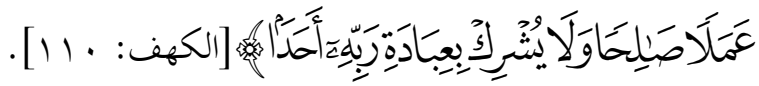
وكـان لابـن القيم رحمـهـ الله موقـف المنكـر للـذكر

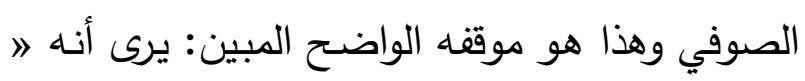

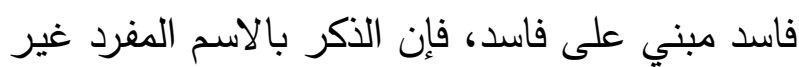

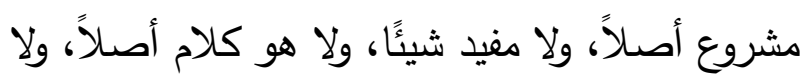

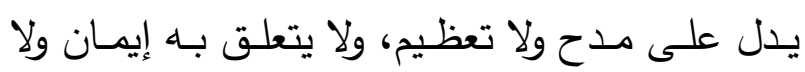

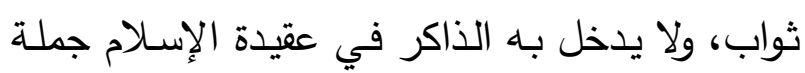
فلو قال الكافر : الله... الله... من أول عمره إلى آخره

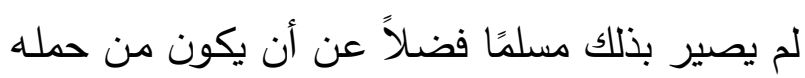

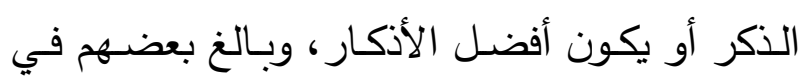

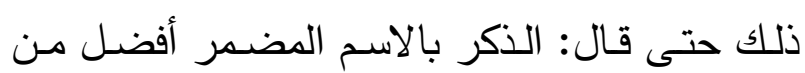
الذكر بالاسم الظاهر، فالذكر بقوله: هو... هو... أفضل من الذكر بقولهم: الله... الله. وكل هذا من أنواع الهوس والخيالات الباطلة المفضية بأهلها إلى أنواع الضلالات، فهذا فساد هذا لهات التات

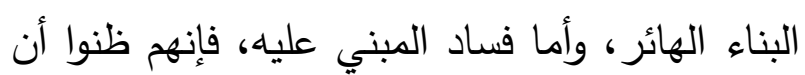
قوله تعالى: فقل: الله الله، وهذا من عدم فهم القوم لكتاب الله، فإن اسم

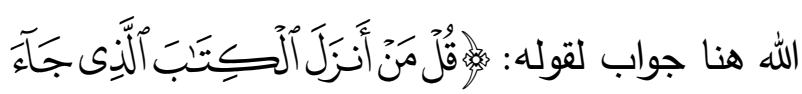

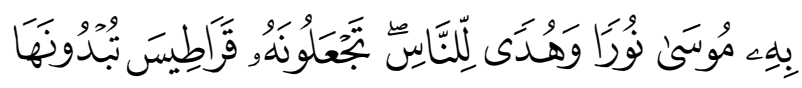

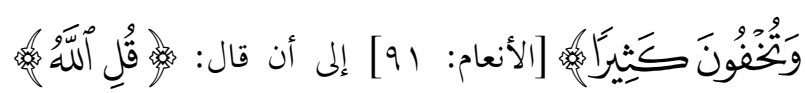
[الأنعام: 19] أي: قل الله أنزله 《) (1). وقد أنكر المفسر القرطبي الذكر عند الصوفية وذلك الكانك (1) طريق الهجرتين، لابنـن القيم طا (بيـروت: دار الكتب العلميـة -

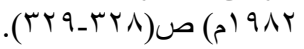


من مائتي عازف من الرجال والنساء، وكبار الأتباع

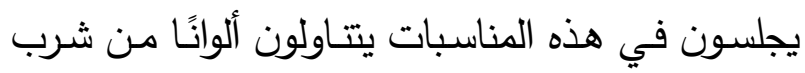

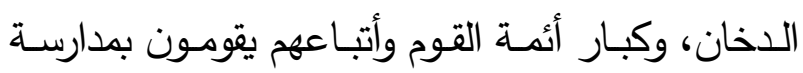

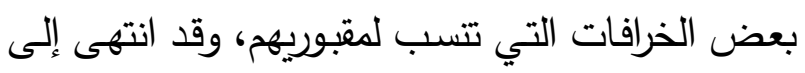

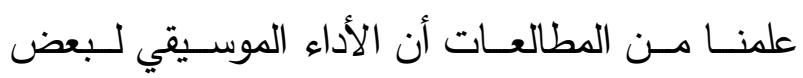
الطرق الصـوفية الحديثة مستمد ممـا يسمى " كورال صلوات الآحاد المسيحية «(). وقـال عبـدالفتاح أبوغدة في تعليقـه على " رســالة المستر شدينه: " بقي شيء آخر أرى التتبيه عليه، وهو شائع اليوم في كثير من حلق الذكر في زماننا!

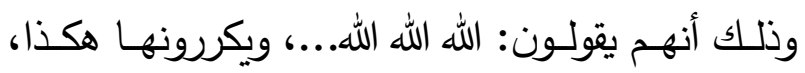

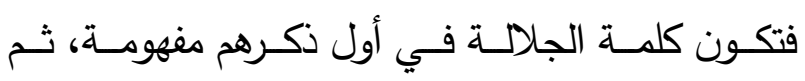
يسرعون بالنطق بها سرعة بالغة متلاحقة، ثم يسرعون

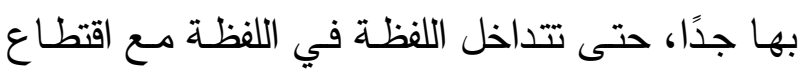
بعض حروفها، فتصير كلمة الجلالمة المعظمة صويًا

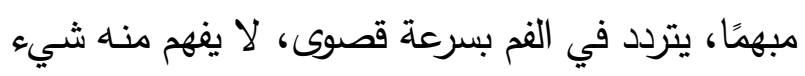

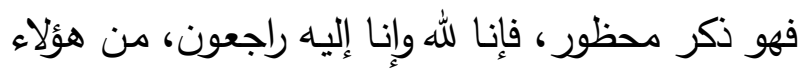
الناكرين الل!! «(

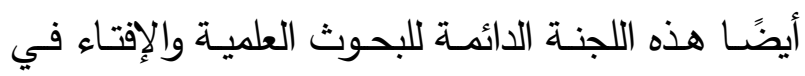
المملكة العربية السعودية، تتكر على الصوفية ما يفعلون أثناء الذكر من رقص وغناء وتمايل باعتباره حلال وذلك بالفتوى رقم (ع ع بـ) والتي جاء فيها:

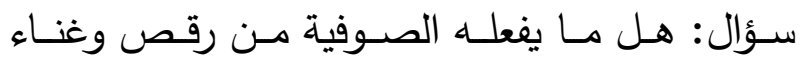

من أخسهم حالاً، والجنون فنون «" (').

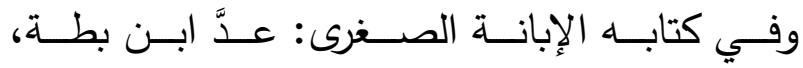

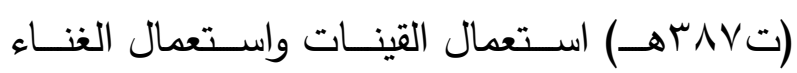
والصراخ ولطم الخدود وتثقيق الثياب عند استماع الذكر والقرآن مما أحدثه الناس وابتداعوه.

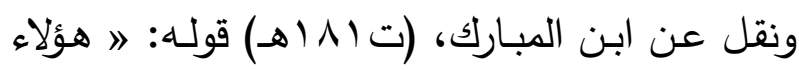

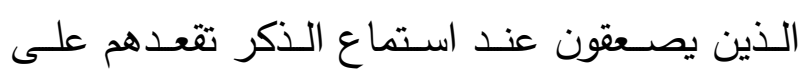
الجدران العاليـة وتقـرأ عليهم وتتظـر هـل يتردون؟ وصـنف مـن النـاس يظهـرون التقشـفـ، اتخـذوا

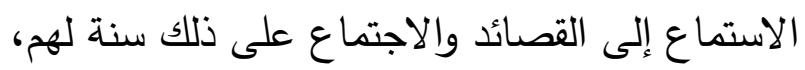

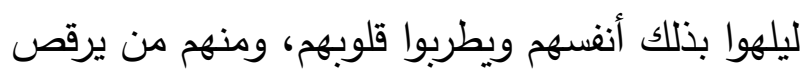
ويصفق بيديه ويخرق ثيابه ويقولون في قيلهم: قال

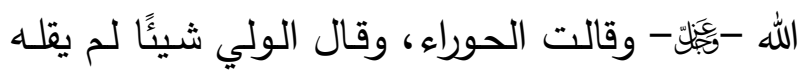
الله ولا جاء في أثر ولا سنة، ولم تقله حوراء ولا قاله ولي، وهذا مبتدع كذب وزور هاء (؟). ولا يزال في عصرنا، ينتشر ما يسمى " وجالس الذكر

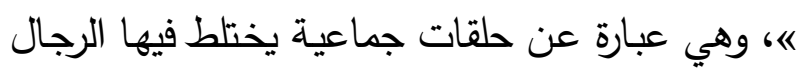
والنساء، ويتخللها الأدعية الجهرية والبدعية، مصحوبة علية

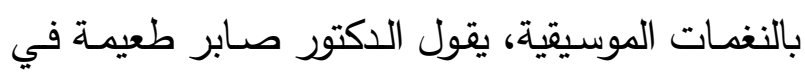

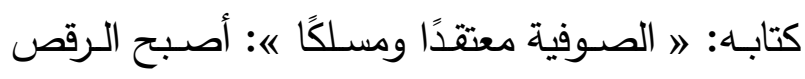

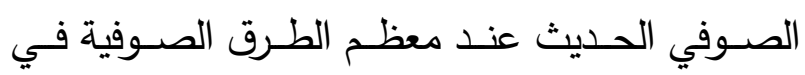

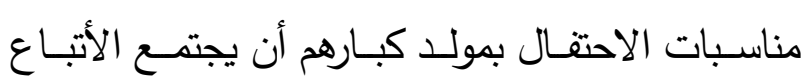

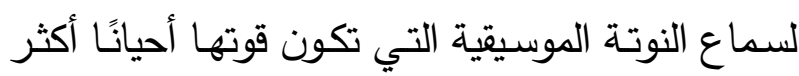

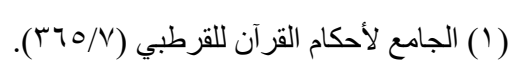

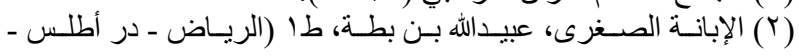

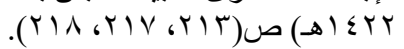


باحث مستشرق فرنسي يدعى 》 كيمون 《 للقول في كتابه 》 باتولوجيا الإسلام «: ما ملخصه: "ا إن الديانـة المحمديـة: -يقصـ الإسـلام- جزام تفثى بين الناس وأخذ يفتك فيهم فتكًا ذربعًا، بل هو مرض إِ وشلل عام، وجنون ذهولي يبعث الإنسان على الخمول والكسل، وما قبر محمد إلا عمود كهربائي يبعث على الجنـون فـي رؤوس المسـلمين، ويلجـئهم إلــى الإتيـان بمظـاهر الصـرع العامـة والذهول العقلي وتكـرار لفظـه: »الله «《 إلى ما لا نهاية.... «(ץ). ومن الثواهد على أن هذا الذكر الصوفي، انعكس سلبًا على ملى الإســام وأهلهـ -مـا قالـه الأسـتاذ محمد شـقفة في كتابـه: 》التصوف بين الحق والخلق《 ما نصه: " وقـد حـثثي مـن أثق بـه مـن رجـالات حمـاة بسوريا- أن الجنرال الفرنسي \ سـراي « عندما زار حماة أراد التعرف على معالمها فرافقه أحد الوجهاء المثقفـين، وعنــدما وصــلا إلـى إحــدى الزوايــا الصـوفية- شـاهدا فيها إحـى حلقـات الذكر - -عند الصوفية- والذاكرون وقوفًا يتمايلون ويرقصون فتعجب الجنرال وسأل المرافق. هل هذا من الدين الإسـلامي؟، فأجابه المرافق النبيه بسرعة: لا أبدًا إنه ملهي \ا تياترو « تحــت سـتار الإســلام البـريء مـن هـذه الخرافـات والمساخر «(๕).

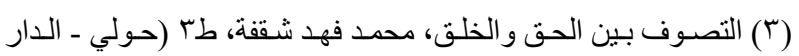

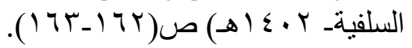

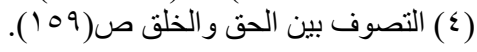

وتمايل ذات اليمين والثمال ذكر كما يسمونه حلال

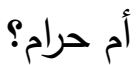
الجـواب: خيـر الكـلام كـلام الله وخيـر الهـدي هـدي

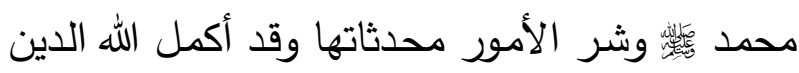

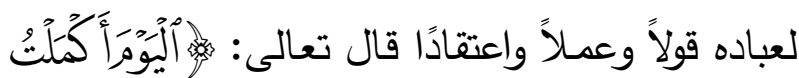

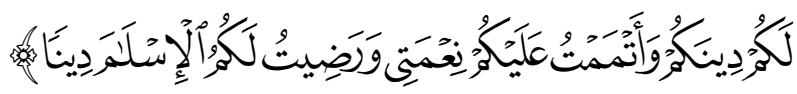
[المائدة: بل

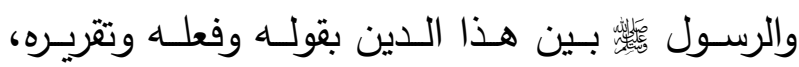

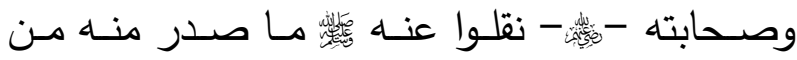
الأقوال والأفعـال والإقـرار، فالـدين كامـل مـن جهـة قواعـده ومـن جهـة بيانـهـ ونقلـهـ. والـذكر نــوع مـن

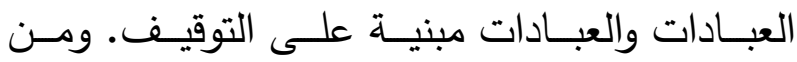
خصص شينًا من العبادات وحدد لـه وقتًا معينًا أو كيفيـة خاصـة لأدائه فهو مطالب بالدليل، ومـا ذكر في السؤال لا نعلم لله أصـلاً شرعًا يعتمد عليه. وقد

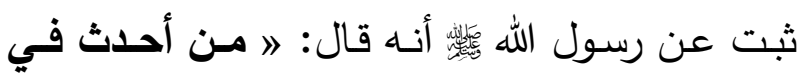

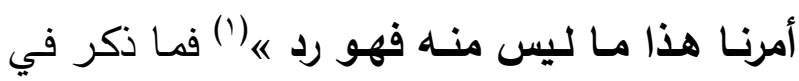
السؤال من النوع المردود «().

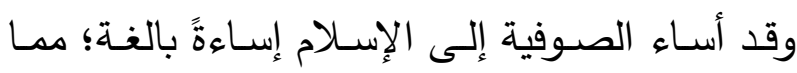
سـبب نفور غيـر الإسـالميين منـه، لمـا شـاهدوا مـن سـلوكهم المنحـرف، وذكـرهم بتكــرار لفـظ: الله، الله فطنوه هو الإسـلام ونفروا منـه مما حدا بأحدهم وهو

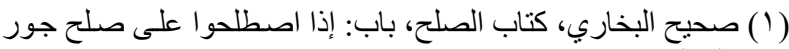

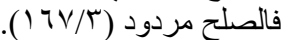

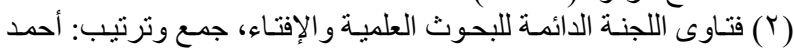

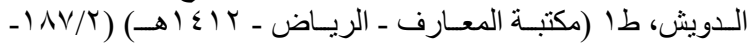


ومخادعة العقل ومخالفة العلم. ثم ساق بعض الأدلة من القرآن التي ترفض هذه الدعوى من أساسها «(). ومما ذكره ابن الجوزي في رده وإنكاره على الصوفية في صسـبتهم للأحـداث واسـتمتاعهم بـالنظر إلىى المـردان قولـه: لا... قـوم صــحبوا المـردان ومنعـوا

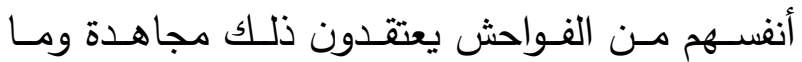
يعلــون أن نفس صــــــهم والنظـر إلـيهم بثــهوة معصية، وهذه من خلال الصوفية المذمومات «(؛). وقـال أن صـحبة الأحداث أقوى حبائل إبليس التي يصيد بها الصوفية(0). ولما كانت دعاوى الصـوفية في نظرهم للأمـرد هي للاعتبـار وزيـادة الإيمـان وإنـه لا خـوف عليهم مـن رؤيتهم، ردّ عليهم ابن عقيل مزاعمهح قائلاً: 》 قول من قال لا أخاف من رؤيـة الصور المستحسنة، ليس بثـيء فـإن الشـريعة جـاءت عامـة الخطـاب لا تميز الأشخاص. - اصغ

وآيـات القرآن تتكر هذه الدعاوي قـال تعـالى:

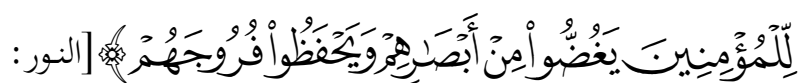
. $[$ r.

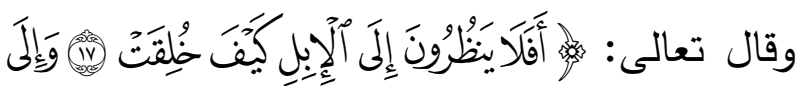

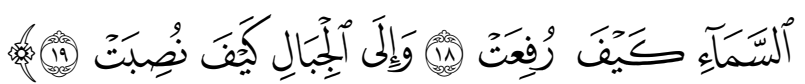

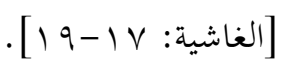
فلم يحل النظر إلا على صور لا ميل للنفس إليها

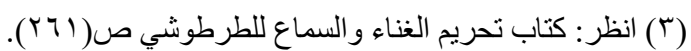

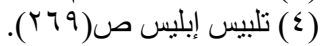

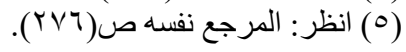

- الرد على دعوى جواز النظر إلى الأمرد: هذا السلوك المصسادم للفطرة، اشتهر عند الصسوفية، وهو من متولدات وإفرازات السماع، وتواترت أخباره

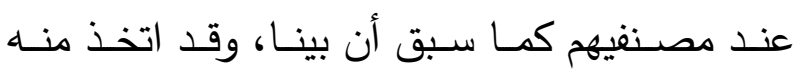
المتصوفة، وسيلة لممارسة السماع وما يتولد منه من رقص، وصعق، ونط، ولطك، وشـق ثياب وخـلاف ذلك من إفرازات لم ينزل بها الله من سلطان ولم يأت عليها دليل ثابت. وقد واجهت تلك البدعـة نفورًا واشـئزازًا من العقول السليمة فتصدى لها العلماء بالنقد والرد، وتشنيع من قال بها ودعا إليها. قال سعيد بن المسيب رحمه الله: إذا رأيتم الرجل يلح النظر إلى غلام أمرد فاتهموه('). وحذر البربهاري (تو بrهـ) مـن مجالسـة هـؤلاء المبتدعـة الذي يـدعون إلى كل هـى وفتنـة مـع النسـاء والمـردان، يفهـم ذلك مسن كلامسه رحمـه الله الذي قال فيه: " واحذر أن تجلس مـع من يدعو إلى الشوق والمحبة ومن يخلو مـع النسـاء، وطريق المذهب، فإن هؤلاء كلهم على الضلالة «(r). وأنكر الطرطوشي رحمـه الله دعوى الصـوفية بجواز النظر إلى الأمـرد بحجـة الاستـلال على الله، وعقد

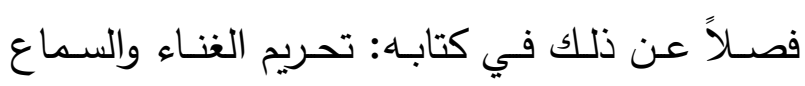

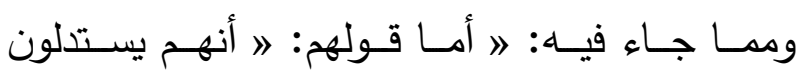
بالصنعة على الصـانع « فنهايـة في متابعـة الهوى،

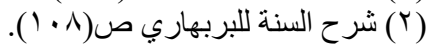


يكرهـون أن يحـــ الرجـل النظـر إلـى الغـلام الأمـرد

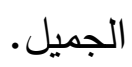

وقال مسلم بن قتيبة: سمعت سفيان الثوري يقول: "

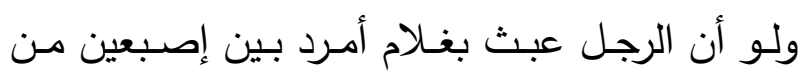

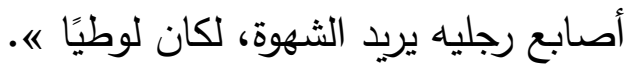

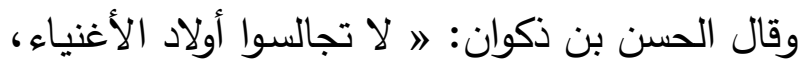

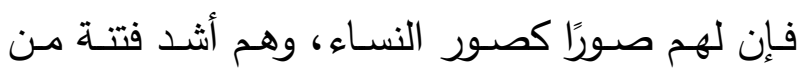

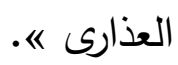

وقال بعض التابعين: 》 اللوطية على ثلاثة أصناف: صنف ينظرون، وصنف يصافحون، وصنف يفعلون

ذلك الفعل «. وبعـد أن سـاق هـــ الأدلـة قـال: وإنمـا تفعـل هـذه

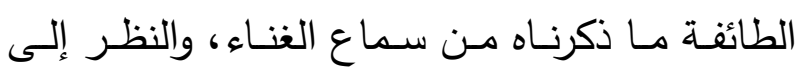

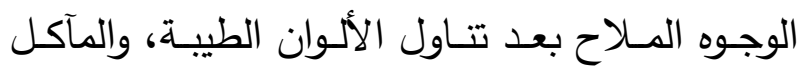

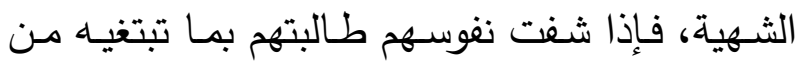
السماع والرقص والاستمتاع بالنظر في وجوه المرد دون الثهوات «(ז). وقـد جـرح الحسافظ ابـن ناصـر (ت ـ00هـ) عدالـة محدث الصسوفية محمد بن طاهر المقدسي، عندما أجاز النظر إلى المرد بقوله: أنه مدن لا يحتج به،

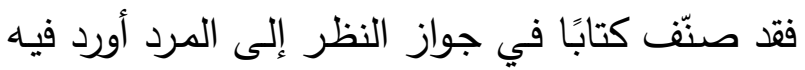

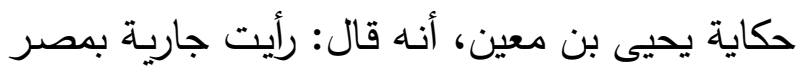

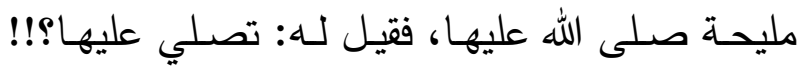
قال: صلى الله عليها وعلى كل مليح، ثم قال: ابن عله لهن
ولاحظ فيها بل عبرة لا يمازجها شهوة. ولا تعتبر بها

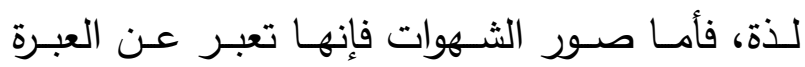
بالثهوة، وكل صورة ليست بعبرة لا ينبغي أن ينظر

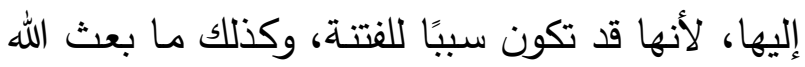

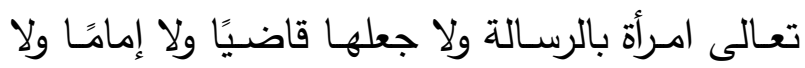

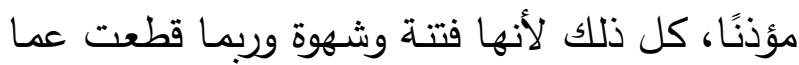

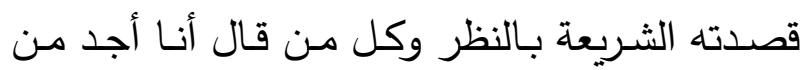
الصور المستحسنة عبرًا كذبناه، وكل من ميز نفسـا بطبيعـة تخرجـه عن طباعنـا بالدعوى كذبناه، وإنما

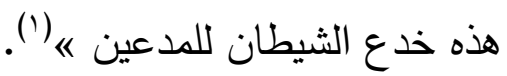

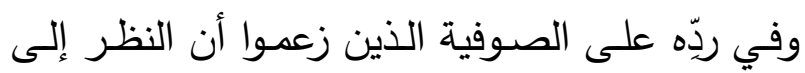

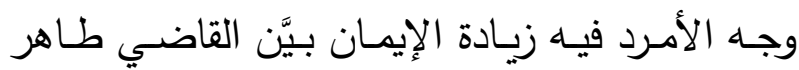

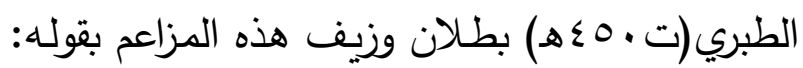

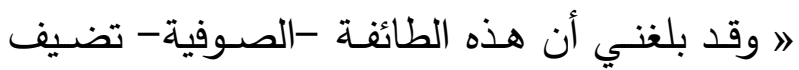

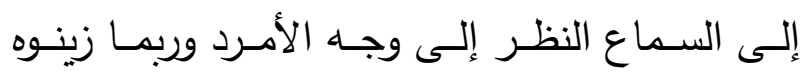

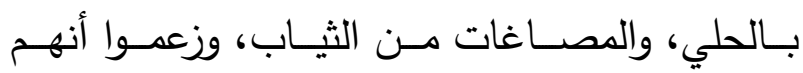

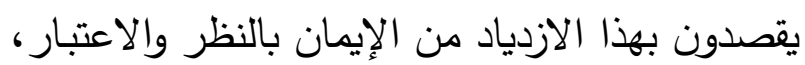

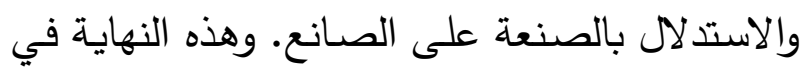
متابعة الهوى، ومخادعة العقل. ثم سـاق رحمـه الله بعض الآيات التي تدعو للتنكر

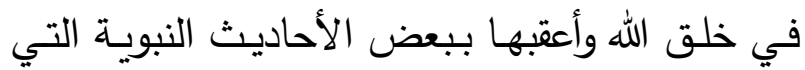

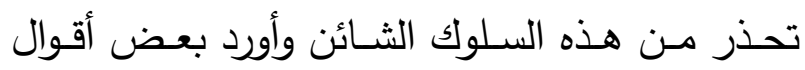
التابعين التي تحذر من النظر إلى الأمرد ومنها: قول عقبة بن الوليد: قال بعض التابعين: » كانوا 
تفصـيلي بحـالهم، فالويـل للقضــاة والحكــام حيـــ يعرفون ويشاهدون ولا ينكرون ولا يغيرون مع قدرتهم عليهم، بـل يخـافون مـنهم ويلتمسـون الـدعاء مـنهم

وقـد أنكـر علـيهم إبـراهيم الحلبـي(ت 904هـ) هـذا السلوك وعده تشبهًا بالبهائم والنصارى بقوله: "واعلم أن صـنيعهم هذا قد اشـتمل على جملـة مـن القبائح منهـا عدم المـروية والتشـبه بالنسـاء والصـبيان قـال سلطان العلماء عز الدين بن عبدالسـلام: الرقص لا يتعاطاه إلا ناقص العقل ولا يصلح إلا للنساء، ومنها التشــبـه بالبهــائم كــالقردة والــذباب ومنهـــا التشــبه بالنصـارى... ومنهـا خلط المعصسية بالعبادة ومنهـا اعتقاد ذلك عبادة وقربـة فكان من هذه الحيثية أشد من الفسق الذي يعتقده فاعله فسقًا، ولقد بلغني ممن أنكلات عليه أنـه قال بعدما غبـت عنـه لا ينكرون على من يشرب الخمر وينكرون علينا أو كما قال، فأقول لو تأمل هذا المسكين تأمل المنصفين، لوجد هذا الفعل أشــ ضـررًا عليـه مـن شـرب الخمر ، فـإن

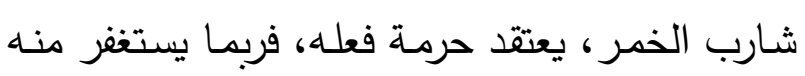
ويندم عليه ويحصل لـه الذلتة والانكسار ويقابل من الخلـق بـاللوم والاحتقــار ، بخـلاف هـؤلاءه، فـإنهم باعتقادهم أنـه عبـادة لا يستغفرون منـه ولا يندمون؛

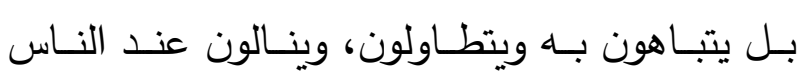
المنزلة والاعتبار والتعظيم، وهذا ما يذكر عند إبليس

(ץ) الصاعقة المحرقة ص(0) ).
ناصر رحمه الله، كان ابن طاهر هذا يذهب مذهب الإباحية، يعني في النظر إلى الملاح ('). ولا ينبغي أن يفوت على المسلم ما أمر الله بـه عباده

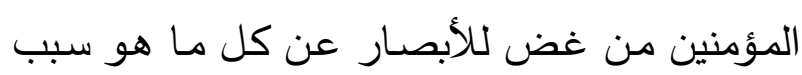

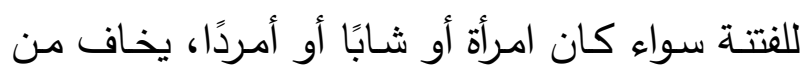
النظر عليه الوقوع في الفتنة.

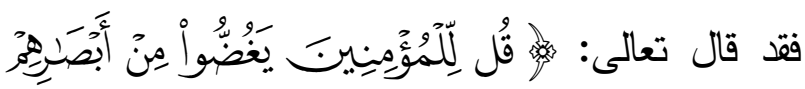

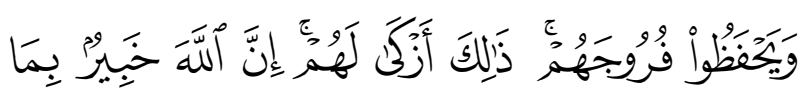

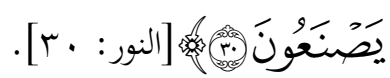

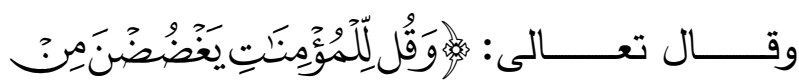

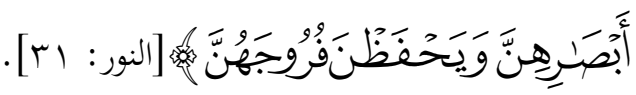
وما أحسن كلام الشيخ عبدالرحمن دمشقية، في حق الق هـؤلاء عنـدما قـال فيههم: " إذا رأى رقص صـوفية زماننـا-الحاضـر - فـي المسـاجد والـدعوات بألحـان

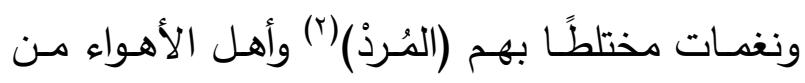
جهّال العـوام والمبتدعـة الطغـام لا يعرفـون الطهـارة والقـرآن والحـلال والحــرام، بـل لا يعرفــون الإيمـان والإســلام، لهـم زعيـق وزئيـر ونهـاق يشـبـه نهـاق الحمير ، يبدلون كلام الله ويغيّرون ذكر الله تعالى، ثم يتلفظون بألفاظ مهملة وهذيانات كريهة مثل: هاي، وهوي وهي وهيا- يقول: لا محالة هؤلاء اتخذوا دينهم

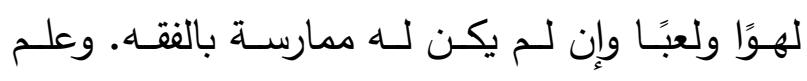

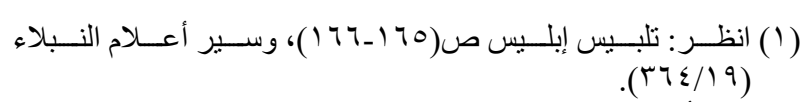
(r) جمع أمرد، و هو الغلام الذي لم تظهر علامـات الرجولة فيه، كظهور اللحية وخثونة الصردو وهو الغلام الصي 


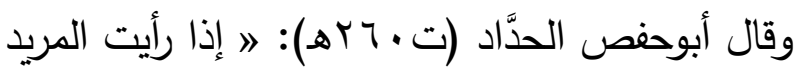

يحب السماع فاعلم أن فيه بقية من البطالة «ه(o). وعبدالقادر الجيلاني (ت ال70هـ) رحمه الله من كبار

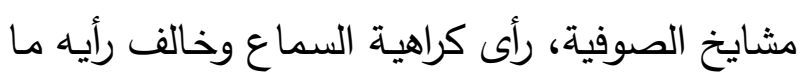

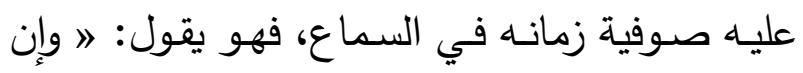
كنا لا نرى بالسماع والقول والقصب والرقص، وقد قدمنا كراهيته؛ إلا أننا قد ذكرنا ذلك على مالك ما قد لهج أهل زماننا في أربطتهم ومجامعهم "(؟).

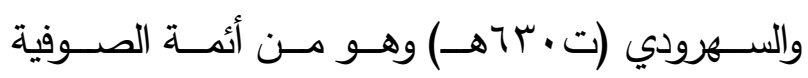
ومصنفيهم في كتابه: " عوارف المعارف 《 يرفض هذه ونه الظاهرة المقيتة، وما يصاحبها من سلوكيات شاذة، فهو يقول: 》 إن أنصف المنصف، وتنكر في اجتماع أهل الزمان وقعود المغني بدفه، والمشبب بشبابته، وتصوره في نفسـ، هل وقع مثل هذا الجلوس والكيئة بحضـرة

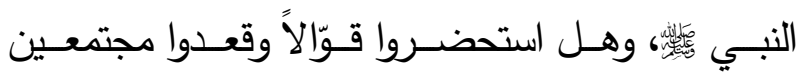

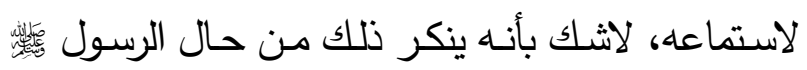

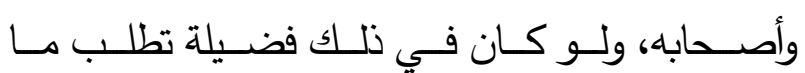
أهملوها « إه (v) وقد ردَّ في مصنفه 》 هوارف المعارف 《 حديث أنس

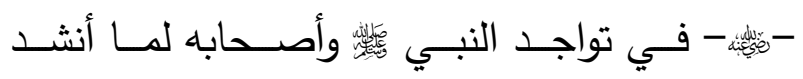
الأعرابي: قد لسعت حية الهوى كبدي -والذي استدل

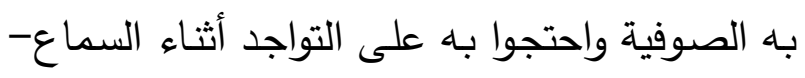

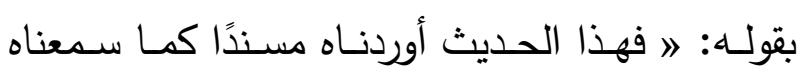

(0) الرسالة القشيرية ص(9 (0) (0).

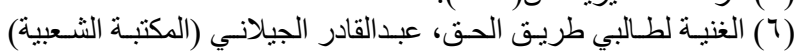
( ) ( $7 \mathrm{~V} / \mathrm{T})$

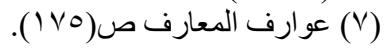

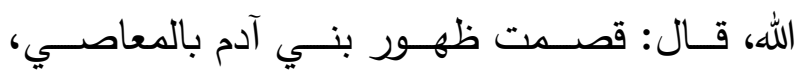

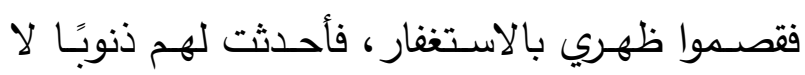

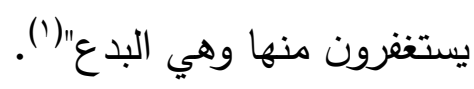

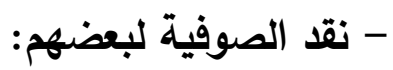

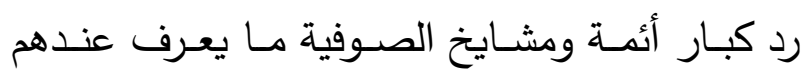

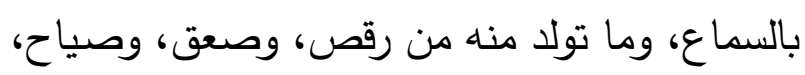

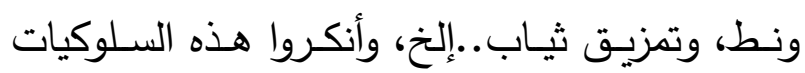
على أهلها. أبـوعلي الروذبـاري (ت بrاهــمن كبـار الصــوفية،

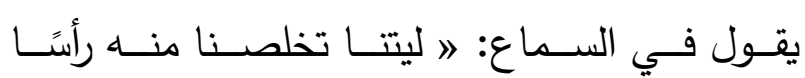
برأس" (r). ويستتكر على من يستمع للملاهي من هؤلاء السذَّج،

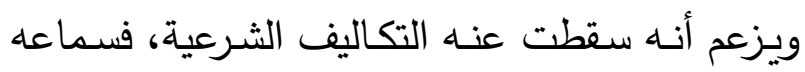
لها حـلال، لأنـه قد وصـل إلى درجـة لا يؤثر فيـه

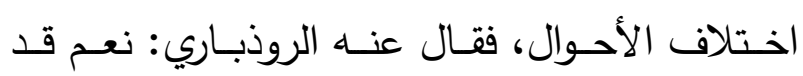
وصل، ولكن إلى سقر ().

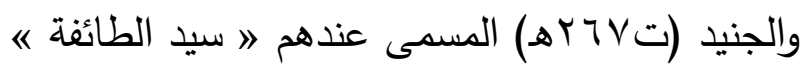
يستنكر هذه الرعونات التي تصدر من بعضهم، ذلك الك الك

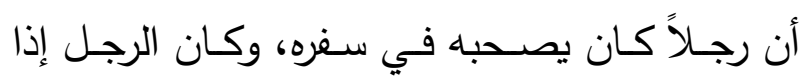

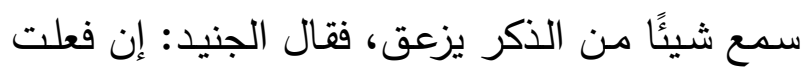
ذلك مرة أخرى لم تصحبني (؛).

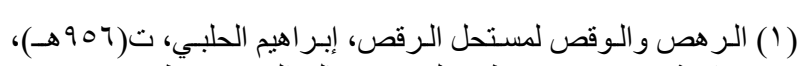

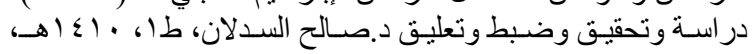

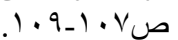

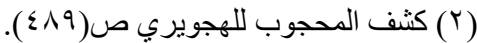

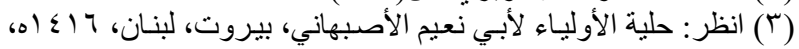

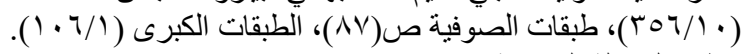

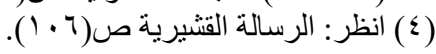


أصيب شيئًا أدخل به عليكم إلا هذا ه(ء). وعدَّ الطوسي -صـاحب 》 اللمع " وهو أحد أئمتهم الكبار - أن هذا السماع هو سماع أهل الباطل فهو يقول: 》 سماع الأوتار والمزامير والمعازف والكونـة والطبـل سـماع أهل الباطل، وهو المحظور المنهي عنــه بالأخبـار الصــحيحة المرويـة عـن رسـول الله

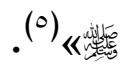
وقـال أبومحمــد الجريـري وهـو مـن أكـابر مشــايخ الصوفية: " من استولت عليه النفس صار أسيرًا في حكم الشـهوات محصسرًا في سـون الهوى فحرّم الله على قلبـه الفوائد فـلا يستلذ بكـلام الحق تعـالى، ولا يستحليه، وإن كثر ترداده على لسـانه «، وذكر عند بعـض العـارفين أصـــاب القصــائد فتـال: هــؤلاء الفرّارون من الله لو ناصحوا الله وصدقوا لأفادهم في سرائرهم ما يشغلهم عن كثرة التلاقي «"جا". وقد ردَّ القشيري أحد أئمسة الصوفية على غلاتهح في مسألة جواز النظر إلى الأمرد وقال قولاً عظيمًا في الرد عليهم وكشف فضائحهم قائلاً: 》 ومن ابتلاه الله

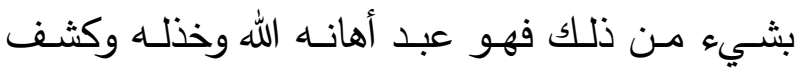
عورته، وأبدى سـوأته في العاجل ولـه عند الله سـوء المنقلب في الآجل « (v). وهذا الواسطي وهو من كبار الصسوفية يقول: 》 إذا

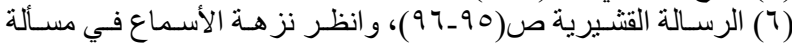

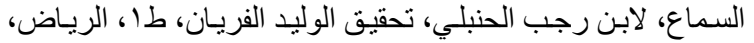

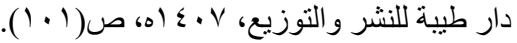

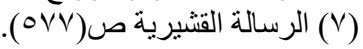

ووجدناه، وقد تكلم في صحته أصحاب الحديث، وما

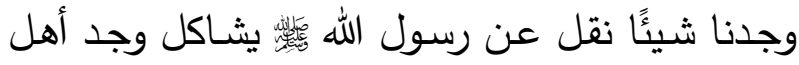
الزمـان وسـماعهم واجتمـاعهم وهيئتهم إلا هنـا، ومـا

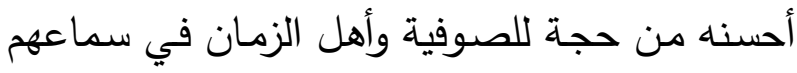

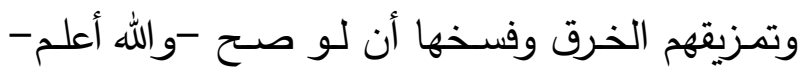

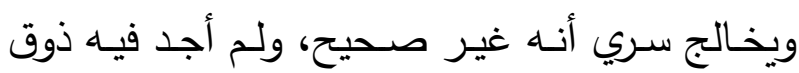

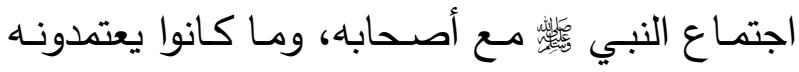
على مـا بلغنا في هذا الحديث، ويأبى القلب قبوله، النها

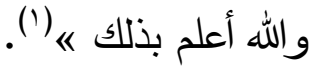

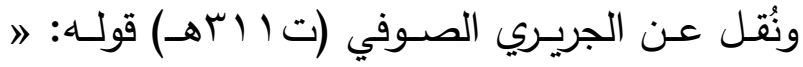
رأيت الجنيد في المنام فقلت: \ هيف حالك يـا أبا القاسم؟ « فقال: 》 طاحت تلك الإشـارات وبادت تلك

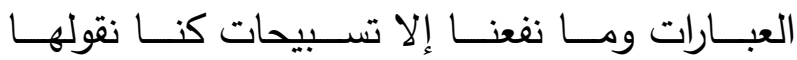

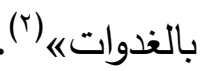
وهذا أبوالحارث الفيض الأولاسي (ت ب Y Yهـ) يربط الـرقص بـإبليس وبفرحـهـ مـــا حققـهـ مـع الصــوفية

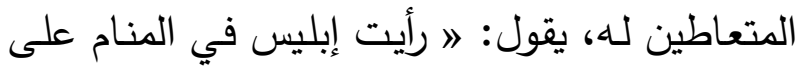

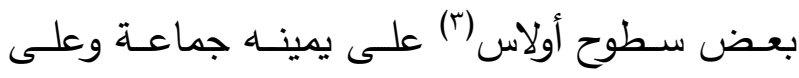
يساره جماعة وعليه ثياب نظاف، فقال لطائفة منهم:

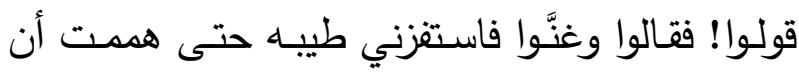

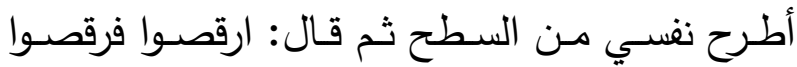

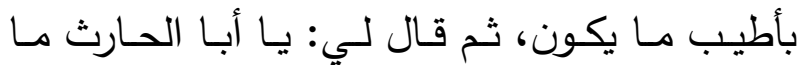

(1) (1) عوارف الرعارف ص(1) (1).

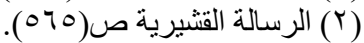

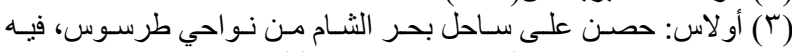

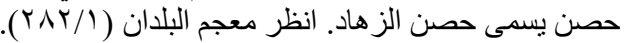


وقصيدته -رحمه الله- المعروفة، في ذم رقص الصوفية، والذي قال فيها:

بمسجد الصصطفى قلنا بلا كذب آلإب

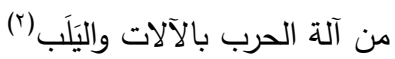

قالوا رقصنا كما الأحبُش قد فد

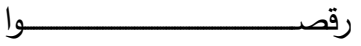
الحُبش ما رقصوا لكنهم لعبوا

وأنثــد أبـوبكر العنبـري (ت Y اعهـ) لنفسـهـ فـي

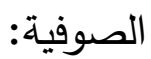

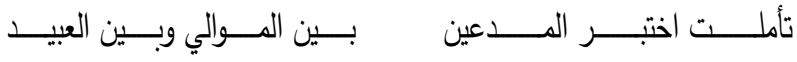

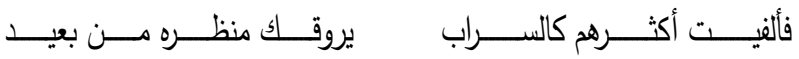

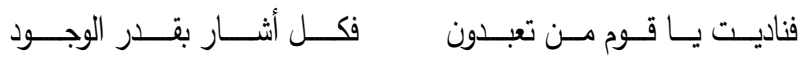

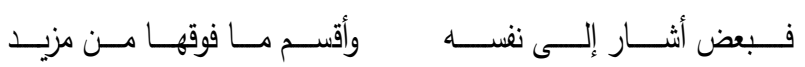

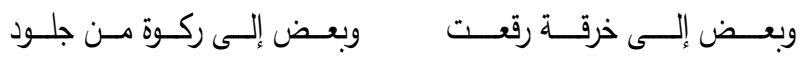

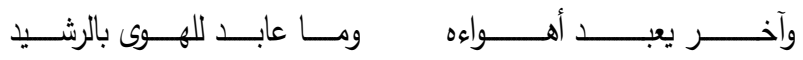

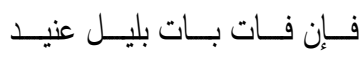
بــين البســـوبــين النثـــيد

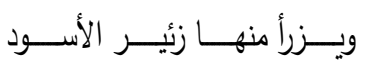

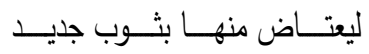

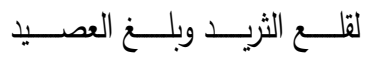

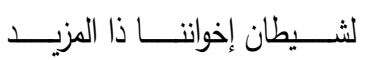

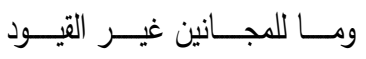

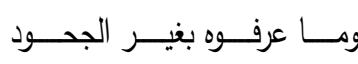

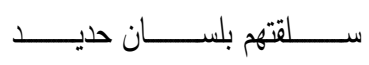
من ليس يعلم مـا في الصدود

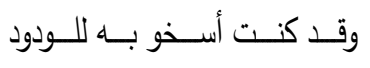
يسـر صـديقي ويشــو الســــود

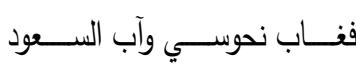

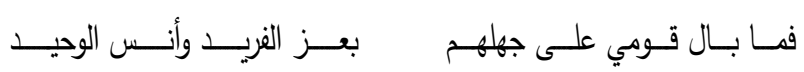

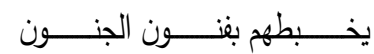

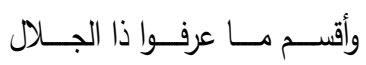

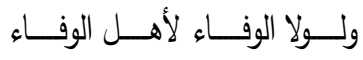

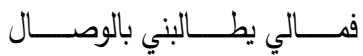

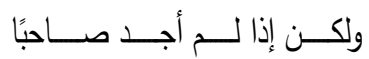

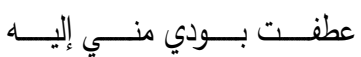

أراد الله تعـالى هـوان عبـــ ألقـاه إلـى هـؤلاء الأنتـان

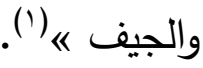
هـذه بعـض أقـوال أئعــة ومشــايخ الصــوفية على لـى

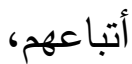
فياليت صسوفية هذا الزمان، يستجيبون لكلام هؤلاء

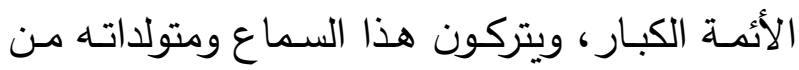
الصـعق والـرقص والزعـق وتمزيـق الثيـاب وغيرهـا، ويتركون الذكر المصاحب للطبل والمزمار والرقص والمعازف، بل ومصـاحبة المردان والاختلاط أحيانًا بالنساء الأجنبيات، نعوذ بالله من البدع والفتن. - لسماع ومتولداته في ميزان الشعر : كان للشعر والثعراء، موقف المنكر لبدع الصـوفية في السماع ومتولداته، فهم الآخرون سطروا أجمل الثعر وأعذبه في إنكار هذه البدعة من خلال نقدهم

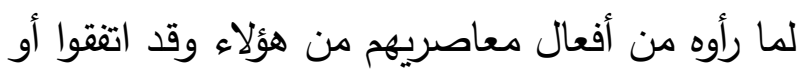
كادوا على أن هذه السلوكيات إنما يقوم بها صبي صنيان

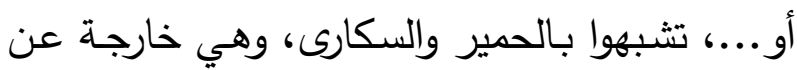
تعاليم الدين الإسلامي الحنيف.

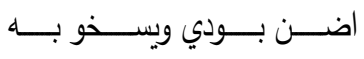
ودع الذين إذا أتوك تسكواوإذا خلوا فهم ذئاب خفاف 
وقال أبواسحاق الشيرازي الفقيه لبعضهم:

فقــل لهــم واهـــون بـالحلول

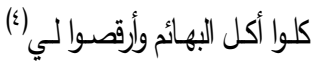

إلا أخو الضعف القصير الباع

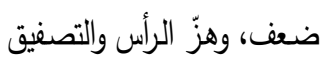

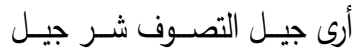

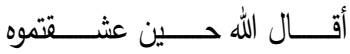

ولــــس يحتــاج إلــى الســماع

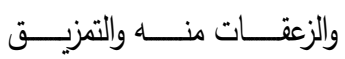

وأنشد البنا السرقسطي:

وألقــى الأخضــري اللائمــة علـى الصــوفية الـذين يرقصون وينبحون ويصيحون حيث قال:

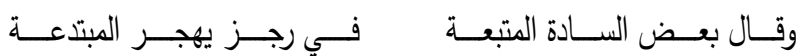

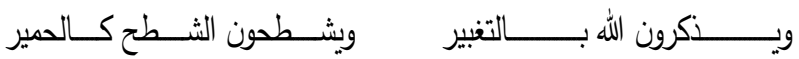

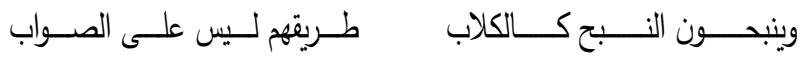

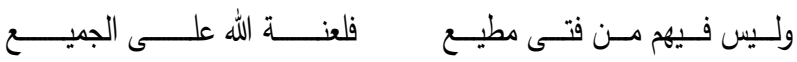

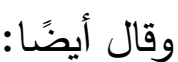

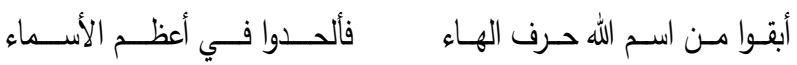

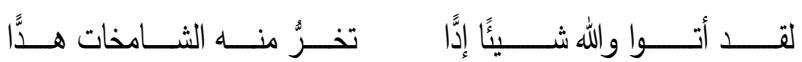

وذمهم آخر بقوله:

الــرقص نقـص والســماع وكـذا التواجد خفـهـ بـالرأس بل للذي طحنوه بالأضراس z

والله ما رقصوا لطاعة ربهم

وقـال آخـر أيضًا بـذههم، ويخص مـنهم مـن جعل العمائم الخضر علامة الشرف في النسب، يقول: أقـال الله صـفق لـي وغنـى وسم الرقص والتصفيق ذكرا

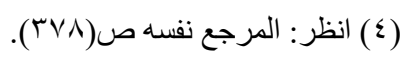

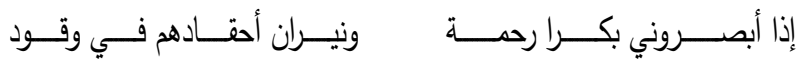

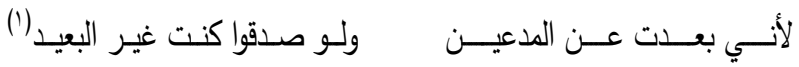

وأنشد الحسن بن علي بن يسار :

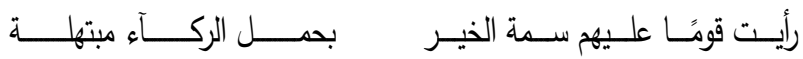

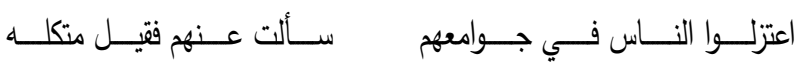

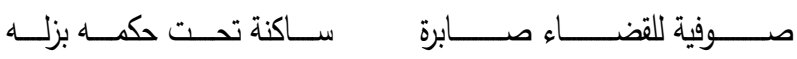

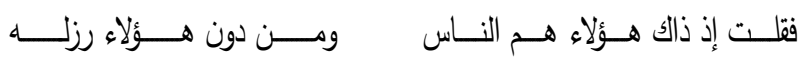

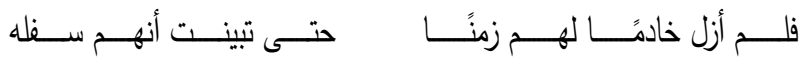

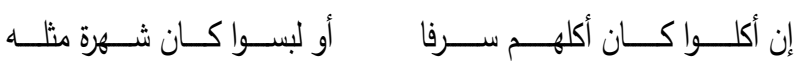
سـلـ شــــهم والكبيـــر مختبـرًاً

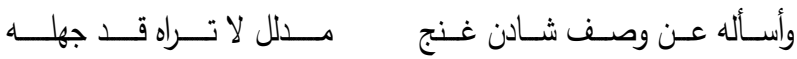

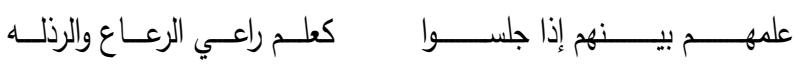

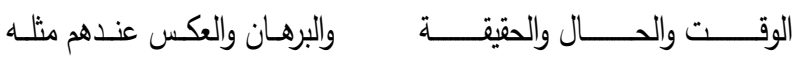

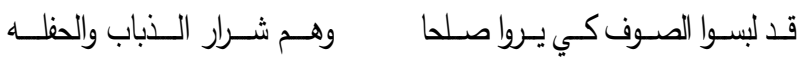

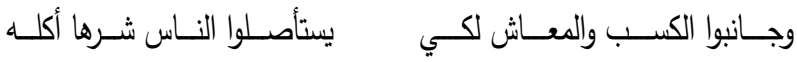

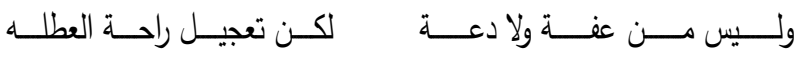

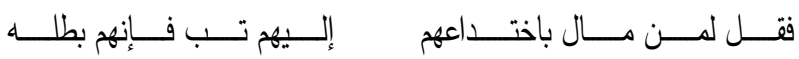

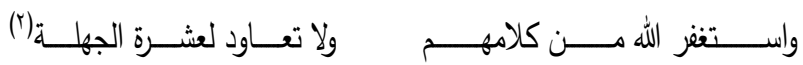

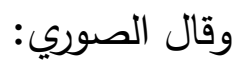
صــــار التصــــوف مخرقـــة

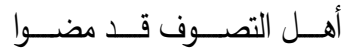

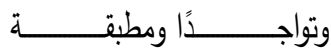
ســـن الطريــــق الملحقــــة منــــــه العيـــــون المحدق لـــــة وهمــــوم ســـرك مطرقــــة(")

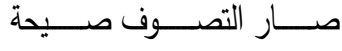

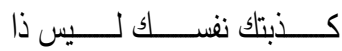
حتـــى تكـــــن بعــين مـــن تجـــري عليــــك صـــــروفه 
فـأتى بــا الثـرك المحـيط

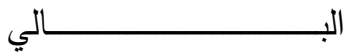

الأثواب، والأديـان والأحـوال

شغلاً به عن سائر الأشغال

عنهـــا، وســـار القــومُ ذات

مالِ

صُسمَّاً، وعميانـاُ ذوي إهـــال

فأطالهـا، عدُوه في الأثتـال

عشـرُ ، فخفــف، أنـــت ذو الو

ل

ضـكٍِ بـلا أدب، ولا إجمال

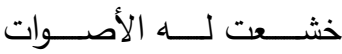

الإجلال

الشـــيخ مــن متــرنمِ قــوَّال

طربٌ، وأشـواق لنيل وصـال

حوال، لا أهلاً بذي الأحوال

مـاذا داهـاهم من قبيح فعال

سكر المدام، وذا بلا إثكال

نالت من الخسران كل منال

كتلاعــب الصــبيان فــي

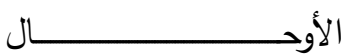

والله لن يرضوا بذي الأفعال

سـرًا وجهـرًا عند كل جدال

هــذا الســماع، فـذالك ديـن

ل

فسـوا الشـرائع تكتفوا بسؤال

مـــن الشــــــان للأنــــال

وينـال فيــه حيـــة المحتــال

بـالحق، ديــن الرســل، لا لغ

ل

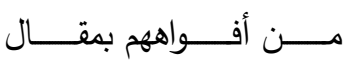

تـالله مـا ظفـر العـدو بمثلهـا

نصـب الحبـال لهـم، فلـم يقعـوا

فــإذا هـــوا وســـ العــرين

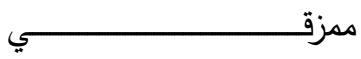

لا يســمعون ســـوى الــذي

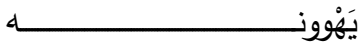

ودعــــا إلـــــــات اليمـين

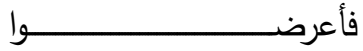

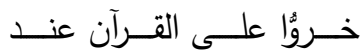

ماعه

وإذا تـلا القـاري عليهم سـورة

ويقول قائلهم: أطلتَ، وليس

ذا

هذا، وكم لغوِ، وكم صـخب، وك

حتـى إذا قـام السـماع لـديهم

وامتست الأعناق، تسمع وحي إدي

ذالك

وتحركـــت تلـــك الــرؤوس،

وهزهـــ

فهنالــــك الأشـــــــ والأثـــــان

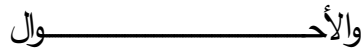

تالله لو كانت صدحاةً أبصروا

لكنَّمـا سُكرُ السماع أثند من

فإذإ همـا اجتمعسا لـنفس مـرةً

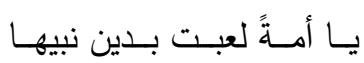

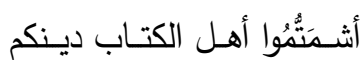

كـم ذا نُعَيَّـر مــنهُ بفـربقكم

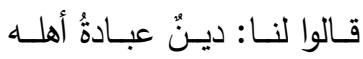

بـل لا تجـيء شـريعة بجوازه
لكان الساق أشرف منك قدرًا

فلـــو كــان الســـادة فـــي

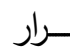
اخض

وقال أبوعبدالله ابن الطوبي الصقلي:

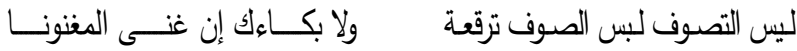
ولا صـياح ولا رقـص ولا حـراب ولا تغاش كأن قد صـرت مجنونًا

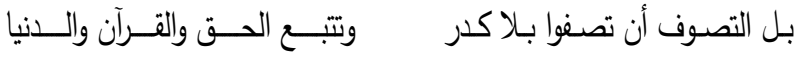

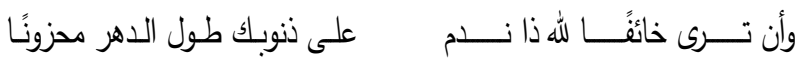

وقال شاعر آخر :

أيا جيلاً تصوَّف عن فضولٍ تنـاقلتم جهـولاً عـن جهـول

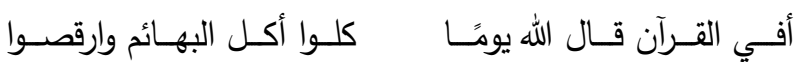

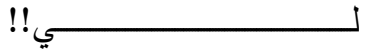

وفي إغاثة اللهفان لابن القيم قال القائل:

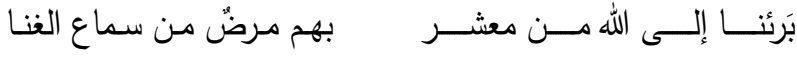

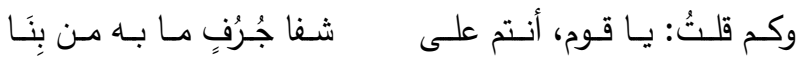

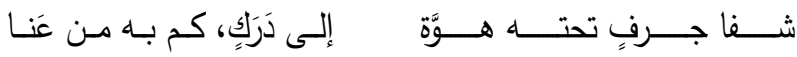

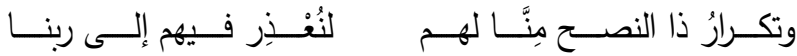

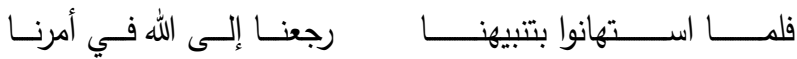

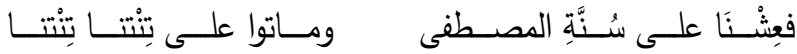
أيضًا في إغاثة اللهفان، قال ابن القيم: جعلوا السـماع مطيـةً لهـواهُمُ وغلوا فقالوا فيـه كل محسال

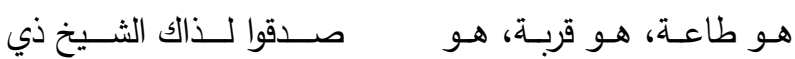

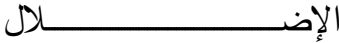
نة

شـيخ قديم، صـادهم بتحيـل حتى أجـابوا دعـوة المحتـال ورأوا سماع الشعر أنفع للفتى مـن أوجـهِ سـبعِ لهـم بتـوال

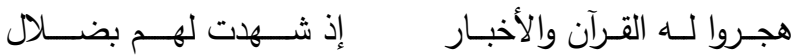
مـن مـثلهم، واخيبـة الآمــال والآث 


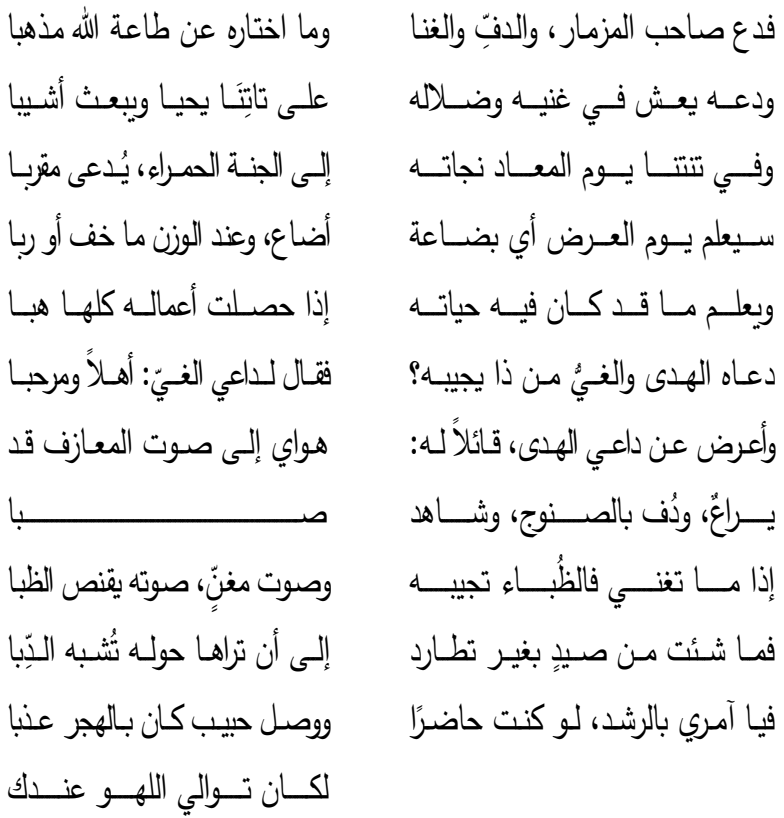

وقد قيل -عن هذا السماع-في إغاثة اللهفان: لتعلمَ كم خبايا في الزوايا فسـل ذا خبـرة يُنبيكـك عنــه

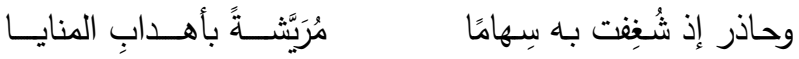

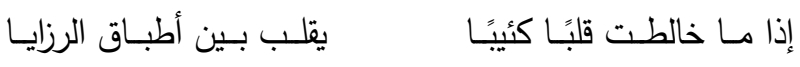

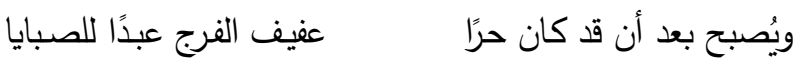
ويُعطي من بـه يُغني غناء وذلك منـه من شر العطايا

وقال ابن القيم رحمه الله في إغاثة اللهفان، وهو يصف من اصطاده الثيطان في هذا السماع البدعي: " وانتقل من الوقار والسكينة إلى كثرة الكلام والكذب، والزهزهـة

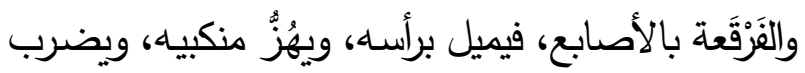
الأرض برجليه، ويدقُ على أمّ رأسـه بيديه، ويثِبُ وثبات

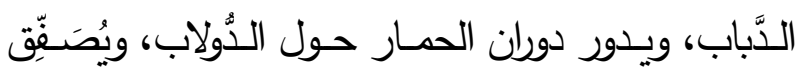
بيده تصفيق النسوان، ويَخُور من الوَجْد كخوران الثيران، وتارة يتأوه تأوّه الحزين، وتارة يَزْعَق زَعَقَات المجـانين، ولقد صدق الخبيزُ به من أهله حيث يقول:

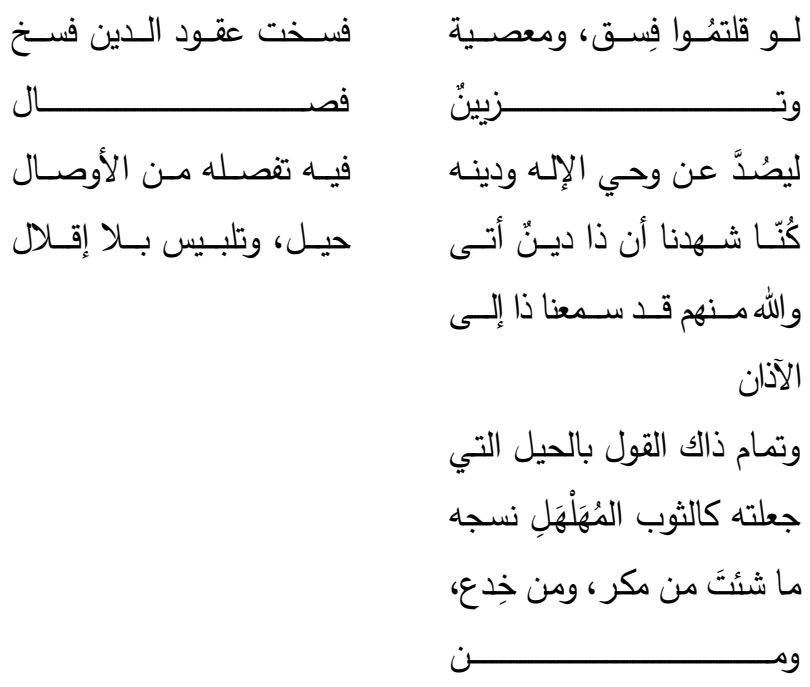

وقال ابن القيم رحمه الله عن السماع الصوفي: هذا السماع الشيطاني المضادُّ للسماع الرحماني، لـه فـي الثـرع بِضــعة عشـر اسـمًا: اللهـو، واللغــو، والباطل، والززور ، والمكـاء، والتصـدية، ورقيـة الزنـا، وقرآن الشيطان، ومُنبت النفاق في القلب، والصـوت الأحمــق، والصــوت الفــاجر ، وصــوت الثـيطان، ومزمور الشيطان، والشُّمود.

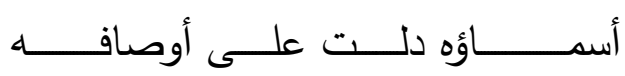

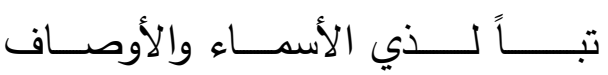
فنذكر مخازي هذه الأسماء، ووقوعها عليه في كلام

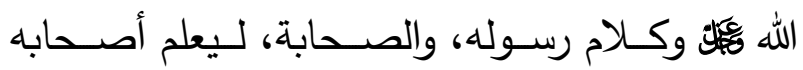
وأهله بما به ظفروا، وأيّ تجارة رابحة خسروا: 
ونظم شرف الدين المقري اليمني (ت اسمده) في ذم الرقص عند الصوفية قائلاً:

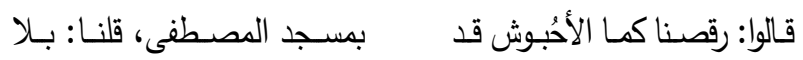

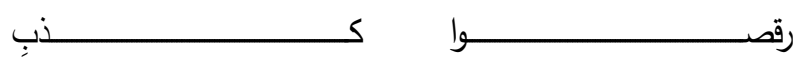

الحُبْشُ ما رقصوا، لكنهم لعبوا من آلَّة الحرب بالآلات والتَلَب

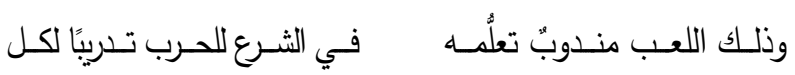

$\left({ }^{*}\right)(r)$

وقد هجاهم ظهير الدين قاضـي السّالّامية(ت • ( آهـ) الذي هجـا مكي شيخ زاويـة الفقراء بـالبوازيج، البلدة القريبة من السّّلامية، بقوله:

ألا قل لمكّي قول النصوح فحق النصيحة أن تُبع متى سمع الناس في دينهم بأن الغناء سنة ثُبَع وأن يأكل المرء أكل البعير ويرقص في الجمع حتى يقع

ولو كان طاوي الحشاء جائعًا لما دار من طرب

$$
\text { واستمع }
$$

وقالوا سكرنا بحب الإله وما أسكر القوم إلا القِصع

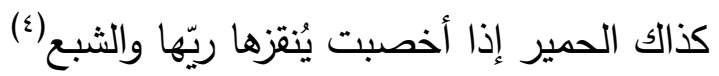

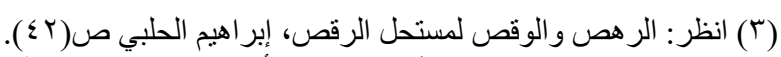

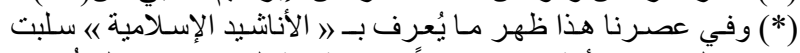

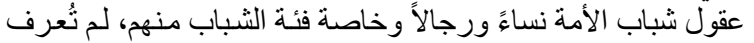

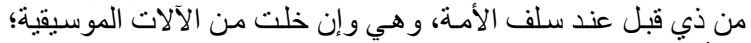

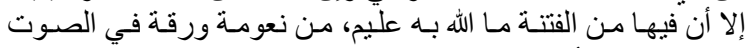

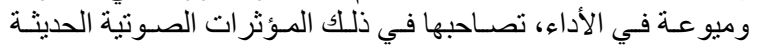

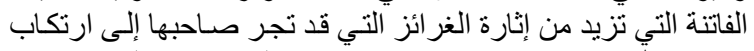

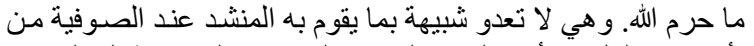

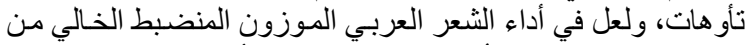

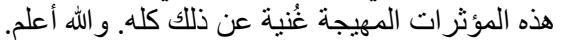

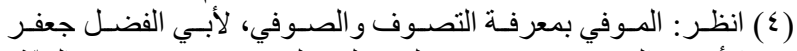

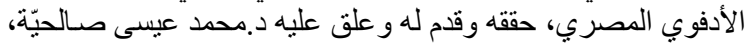

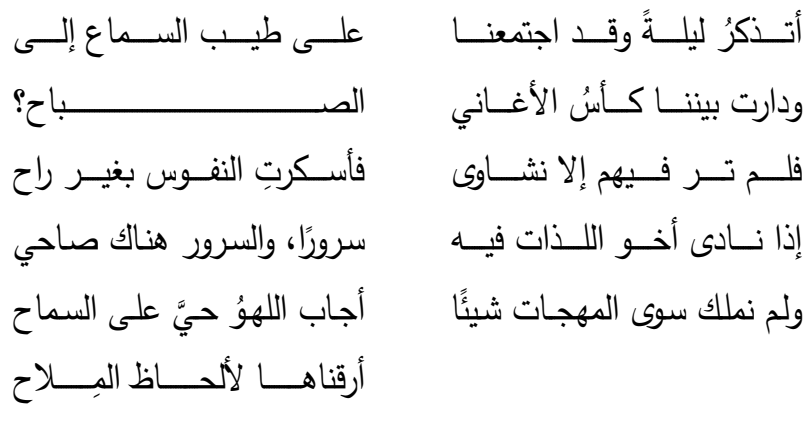

ونظم السـناقي صساحب النهايـة في رسـالته في ذم المتصوفة قائلاً:

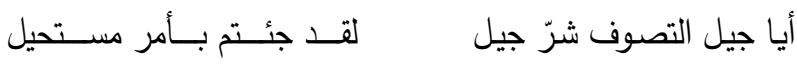

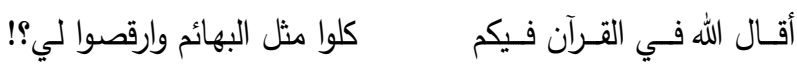
أيرقص مـن لـه عقل وديـن ك كـدبّ بالــدفوف وبــالطبول

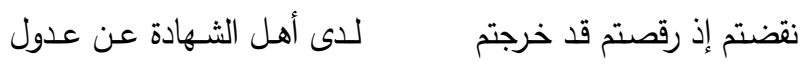

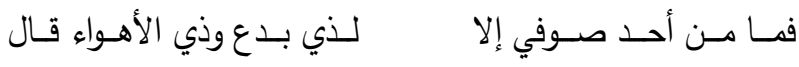

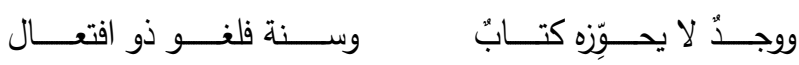

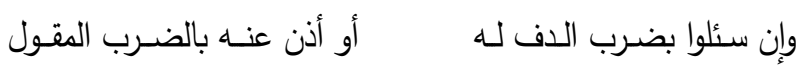

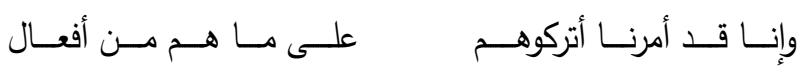

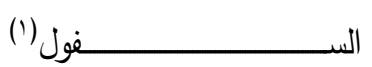

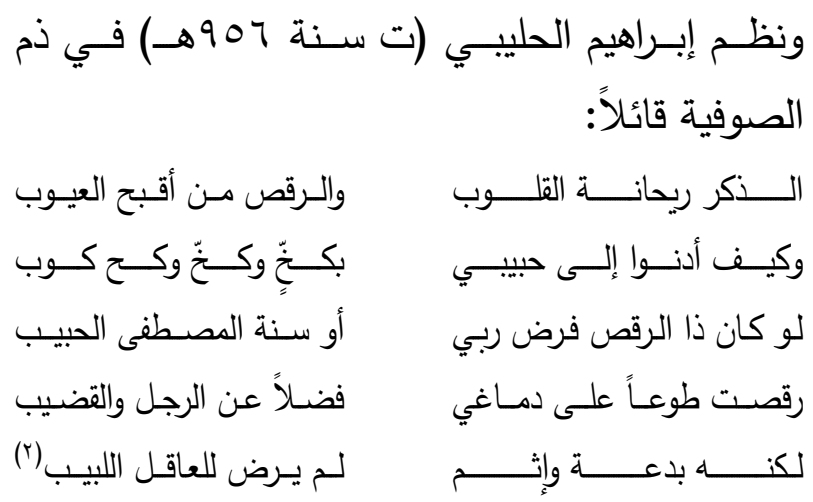


مصر وعصـر ، وهي تؤكد وحدة منهج أهل السنة

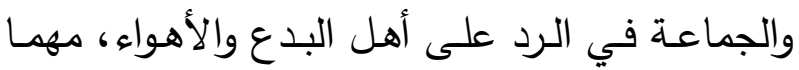
تباعدت بهم العصور والأمصار .

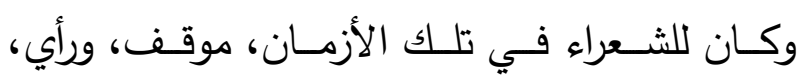
اتصف بالنقد والانكار على هذه السلوكيات المحدثة. فهرس المصادر والمراجع

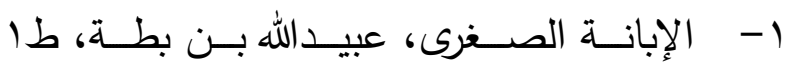

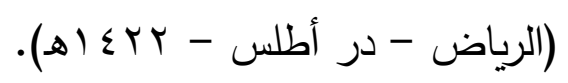

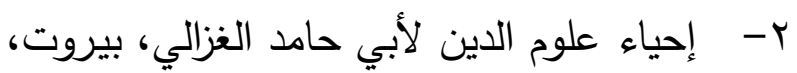

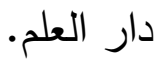
ז- الآداب الثرعية، لأبي عبدالله محمد ابن مفلح،

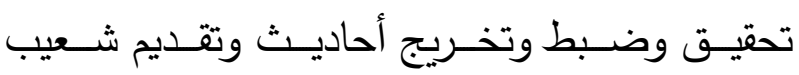

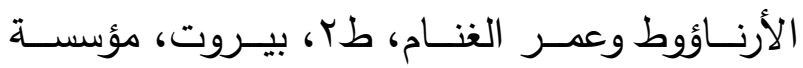

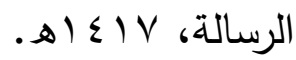
ع - - آداب المريـدين للســـروردي، تحقيـق فهـيم شلتوت، القاهرة، دار الوطن العربي.

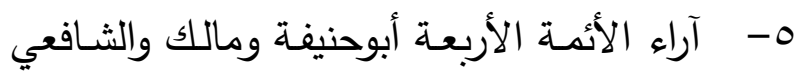
وأحمد في الغناء 1- الاستقامة لابن تيميـة، تحقيق د. رشـاد سـالم،

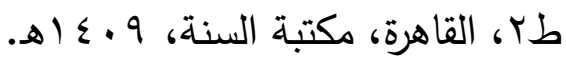

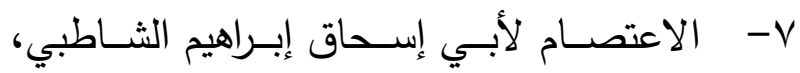
تحقيـقق: عبــدالرزاق المهـدي، طا (بيــروت: دار

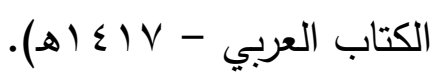

1- - إغاثة اللهفان من مصايد الشيطان، لابن القيم، تحقيق وتصحيح وتعليق محمد الفقي، بيروت، دار

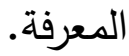

\section{الخاتمة}

الحمد لله رب العالمين والصـلاة والسـلام على أشرف

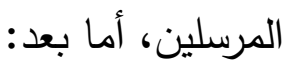
أرجو الله أن أكون قد وفقت في هذا البحن البحثبلتناول

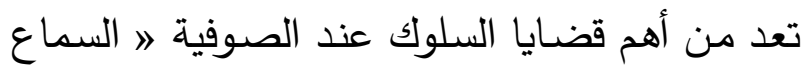
" وقد عرضت شبهتهم وما أفرزته دن آثار ، ظهرت عليهم، وذلك من خلال ممارساتهم وأقوال مشـايخهم ومصنفيهم. آثار ، ومتوالـدات هذا السلوك، من (رقص وصـقق والزعق ولطم وتمزيق للثياب) تجمّدت في غالبها، عنـدما يمارسـون عبـادة الـذكر ، بمعتقـدهم البـدعي

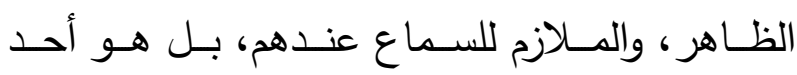

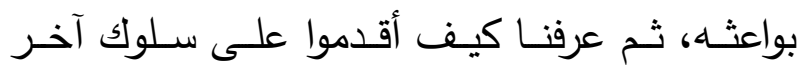
يصادم الفطرة؛ هو اعتقادهم بجواز النظر إلى الأمرد

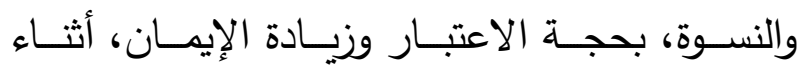

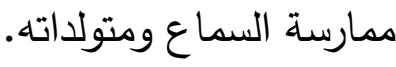
وخلاصــة اعتقــادهم فـي السـماع، أنــه ديـن وقربــة وطاعة لله. وبعد بيان شبهات الصوفية حول السماع، وبواعثه، ومتولداته من خلال أقوال أئمتهم ومشايخهم المثبتة بمؤلفـات مصـنفيهم، وقفنـا على رأي علمــاء الأمسـة إزاءها، وهم الذين اعتمدوا على منهج الثرع في الرد على المخـالف؛ وقد عدّوا هذه السـلوكيات؛ بـدعًا،

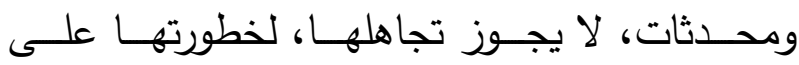

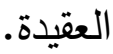
فتواترت الردود، والإنكارات على هذه البدع، في كل 
• ب- ذم مـا عليـه مـدعوا التصـوّف لموفـق الـدين عبدالله بن قدامـه المقدسي، تحقيق زهير الشـاويش، طץ (بيروت: المكتب الإسلامي - ع . ؛ اهـ). ا آ- الذيل طبقات الحنابلة، لابن أبي يعلى، خرج أحاديثه ووضـع حواشيه، أبو حازم أسـامة بن حسن

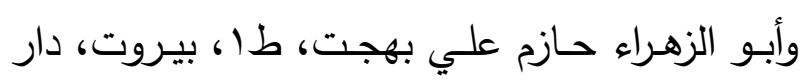

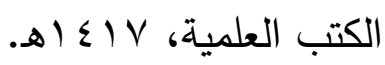
r r- الرد على من يحب السماع/ القاضـي طـاهر الطبري، دراسة وتحقيق: مجدي السيد طا (طنطا دار الصحابة للتراث - . ( ـ (ه). rr- الرسالة القشيرية في علم التصوف، عبدالكريم القشـيري، تحقيـق ودراســة هـاني الحــاج، المكتبــة التوفيقية. ع r- رسالة المسترشدين للحارث المحاسبي، تحقيق: عبدالفتاح أبوغدة، تقديم: حسنين مخلوف. هץ- رسالة في تحريم الجبن الرومي وكتاب تحريم الغناء والسماع، أبو بكر الطرطوشي، تحقيق وتقديم ووضـع فهـارس عبدالمجيد تركي، طا، دار الغـرب

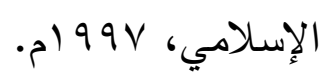
ج ب- الـرهص والــوقص لمسـتحل الـرقص، إبـراهيم الحلبي صححه وعلق عليه حسن السويدان، وقد م لله عبـدالقادر الأرنـاؤوط طا (دمشـق - دار البشـائر، . (ه) V Y - الـرهص والـوقص لمسـتحل الـرقص، إبـراهيم الحلبي، ت (907هـ)، دراسـة وتحقيق وضبط وتعليق

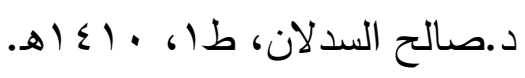

9- الأنـوار القدسية في معرفـة قواعد الصـوفية، عبدالوهاب الشـعراني، تحقيق وتقديم طـه عبدالباقي ســرور ، ومحمــد عيــد الشــافي، بيـروت، مكتبــة

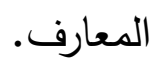
• 1- ترتيـب المـدارك وتقريـب المســالك، للقاضـي عياض، تحقيق عبدالقادر الصحراوي، طن، المغرب، وزارة الأوقاف والثُون الإسلامية، ب • ـ اهـ. 1ا- التصوف الإسلامي في الأدب والأخلاق، زكي مبارك طץ (مصر : دار الكتاب العربي - (اله الهـ). r ا- التصوف بين الحق والخلق، محمد فهد شقفة، طس (حولي - الدار السلفية- ب . ؟ اهـ). r ا- التعرف لمذهب أهل التصوّف، أبي بكر محمد

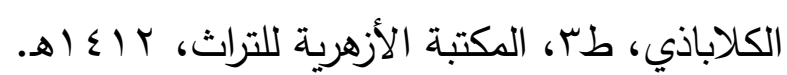
ع ا- تفسير البغـوي، تخـريج وتحقيق محمــ النمـر وعثـان ضـميريـة وسـليمان الحـرش، طب، الريـاض، دار طيبة. 1 - تفسير القرآن العظيم، لابن كثير ، ط9، لبنان، بيروت، دار المعرفة، سو با هـ.

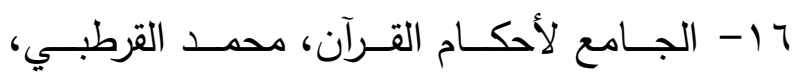
بيروت، دار إحياء التراث العربي.

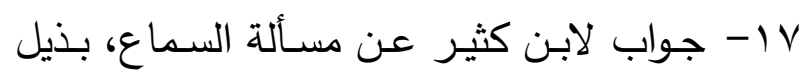
كتاب الكلام على مسألة السماع. 1 1- جـواهر المعـاني علـى بـرادة (دار الجيـل بيروت). 9 1 ا- حلية الأولياء وطبقات الأصفياء، لأبي نعيم أحمد الأصبهاني، بيروت، دار الفكر، 1 إع اهـ. 
^ץ- ظهـر الإســلام/ أحمـد أمسين، طس، بيـروت، الكتاب العربي.

وب- عوارف المعـارف، عمر السـهرودي، القـاهرة، مكتبة القاهرة، سو س اهـ.

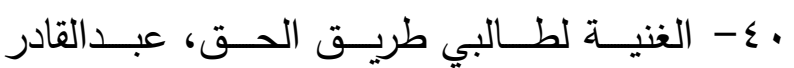
الجيلاني (المكتبة الشعبية). إ- فتـاوى اللجنـة الدائمــة للبحـوث العلميـة والإفتـاء، جمـع وترتيـب: أحمـد الـدوش، طا (مكتبـة المعـارف-

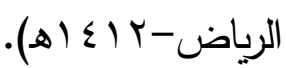
ץء- فتح الباري شرح صحيح البخاري لابن حجر العســقلاني، طـا، القــاهرة، دار الريــاض للتــراث، (ه.V بـ- الفتوحـات المكيـة لابـن عربـي، القـاهرة، دار الكتب العربية الكبرى، و وبا اهـ. عـ- قواعـد الأحكـام فـي مصــالح الأتـام، للعـز بـن عبدالسـلام، تحقيق طله عبدالرؤوف سعد (دار الشرق -

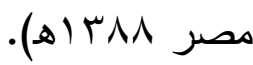
ــ - كتـاب الثـريعة لأبـي بكـر محمــ الآجـري، تحقيـق محمــد إســماعيل طا (بـدون: دار الكتـب

$$
\text { العلمية - } 77 \text { ( أهـ). }
$$

ج६- كثـف الرعـاع عن محرمـات اللهو والسـماع، أحمد الهيثمي، تحقيق محمد عبدالقادر عطا، طا، بيروت، دار الكتب العلمية، 7 ، ـ اهـ. 乏V العبـاس القرطبي، تقديم وتحقيق وتخـريج د.عبـدالله

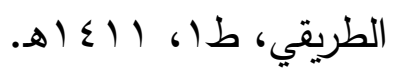

^r- ســن الترمـــي، ضــبط ومراجعــة أصـــول وتصحيح عبدالرحمن عثمان، نشر محمد الكتبي. 9 ץ- سـير أعــلام النـبلاء، محمــد الـذهبي، طوه، بيروت، مؤسسة الرسالة، سا ؟ـ اله. • r- شـرح السـنة لأبـي محمــ الحسـن البربهـاري، تحقيق: خالد الروادي، طب، (الريـاض - دار السلف . اب- شـرح العقيدة الطحاويـة، علي بـن أبـي العزز، تحقيق د.عبدالله التركي، وشعيب الأرناؤوط، مؤسسة الرسالة. ץب- الصـاعقة المحرقـة علىى المتصــوفة الرقصـة المتزندقـة، تـأليف محمـد بـن صـفي الدين الحنفي، تحقيق عبدالرحمن دمشقية، دار عـالم الكتب للنشر

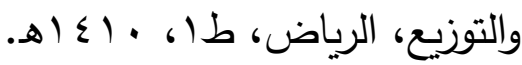
سب- صـحيح البخـاري، محمـد بـن إســاعيل البخـاري، استانبول، المكتبة الإسلامية للطباعة والنشر والتوزيع. ع ب- صفة أهل التصوف للمقدسي نقلاً عن كثف القناع عن حكم الوجد والسماع لأبي العباس أحمد القرطبي، تقديم وتحقيق وتخريج د.عبدالله الطريقي، طا هب- الصــوفية معتقـدًا ومسـلكًا، دم/ صـابر طعيمـة طب (الرياض - عالم الكتب-ه . ـ اهـ). جr- الطبقات الكبرى، عبدالوهاب الثـعراني، طا، بيروت، دار الجيل، 1 • ع أه. V الكتب العلمية - $9 \wedge$ (م). 
خاط. oV

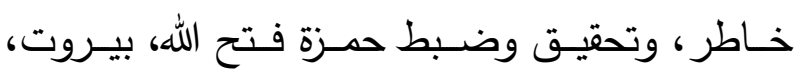
مؤسسة الرسالة، ؟ إع أهـ.

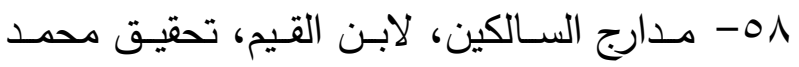

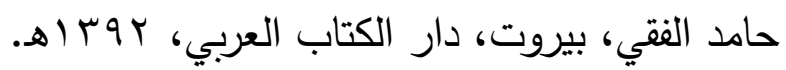

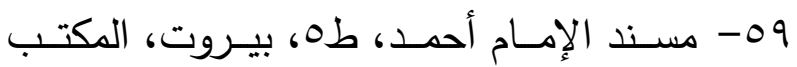

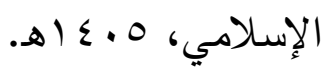

• ؟- المصادر العامّة للتلقي عند الصوفية/ صادقاد

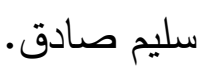
آ- معجم البلدان، يـاقوت الحموي، بيروت، دار

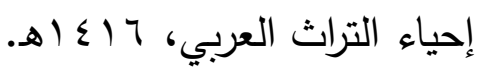
ب آ- المعجم الوسيط، إخراج إبراهيم مصطفى وأحمد

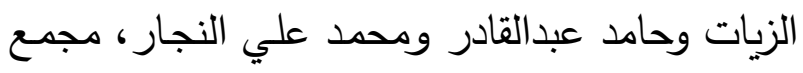

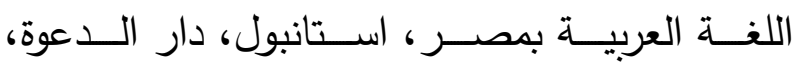
. آه人. بآ- المعيار المعرّب، أحمد الونشريسي، إشراف د.

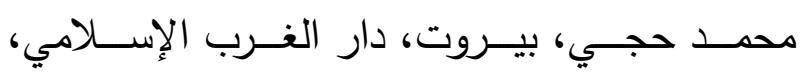
.ه) $\varepsilon$.

ـ ؟- المغني، لابن قدامة، الرياض، مكتبة الرياض الحديثة، ا +ـ اهـ. ه7- مقدّمـة ابن خلدون، عبدالرحمن بن خلدون، ط7، بيروت، دار القلم، 7 •ـ أهـ. 77- مقدمـة كتاب كثـف القنـاع عن حكم الوجد والسماع للقرطبي، تحقيق: د. عبدلله الطريقي. VT- المنار المنيف في الصحيح والضعيف، لابن لهن

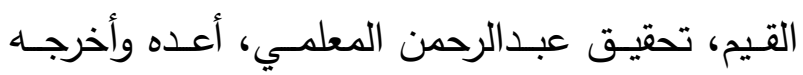

^ـ- كثــف المحجـوب، علـي الهجـويري، دراسـة

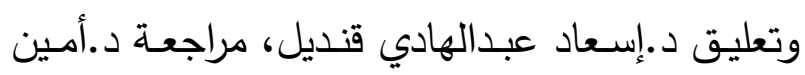

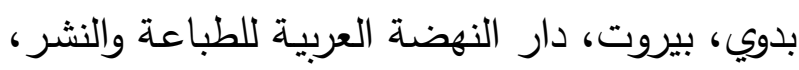

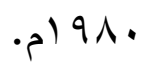
9 - كف الرعاع عن محرمات اللهو والسماع لأبي العباس أحمد بن حجر الهيثمي، تحقيق محمد عطا، طا، بيروت، دار الكتب العلمية، 7 . ــ الهـ.

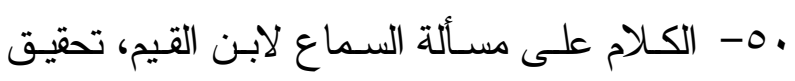

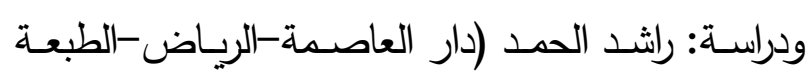

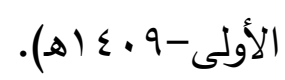
10- الكلام على مسألة السماع، لابن القيم، تحقيق الاولى

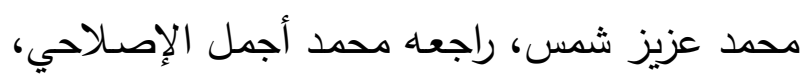

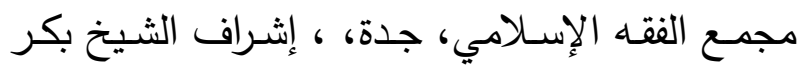

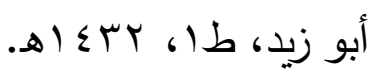
ror- لسان العرب لابن منظور، بيروت، دار القلم.

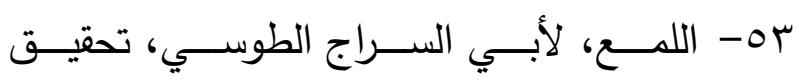

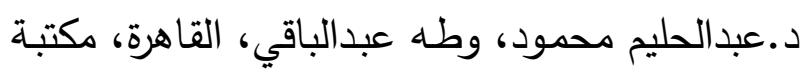
الثقافة الدينية. ــ- لواقح الأنوار في طبقات الأخيار، عبدالوهاب الشعراني، (القاهرة، 970 (م).

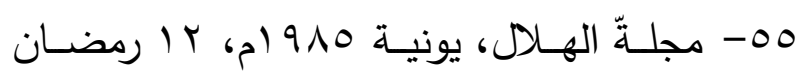
. (ه. 10 10 - مجموع فتاوى شيخ الإسـلام ابن تيميـة، جمع

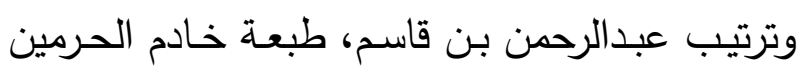

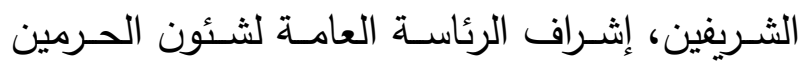
الشريفين 
محمد بن أحمد الجوير

118

منصــور السـماري، طب، الريـاض، دار العاصـمة، جلوي.

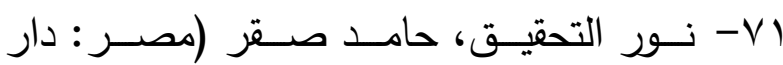

. $) \leqslant 19$

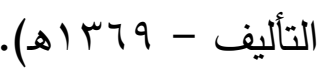

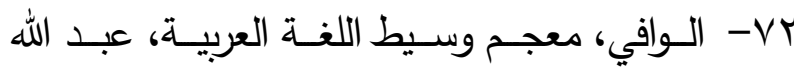

1 آ- الهـوفي بمعرفـة التصـوف والصـوفي/ لأبسي

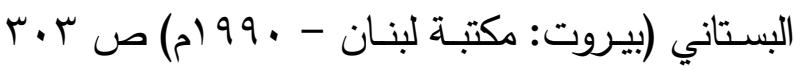

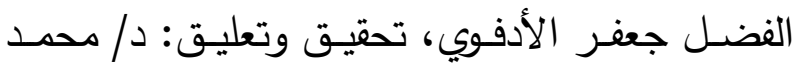

ضالحنة، طا (الكويت - دار المعرفة - 1 مــ (اله).

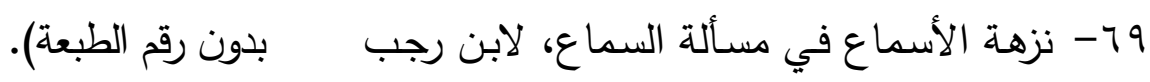

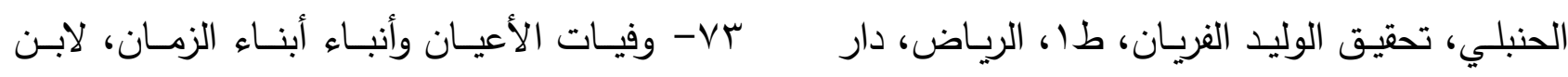

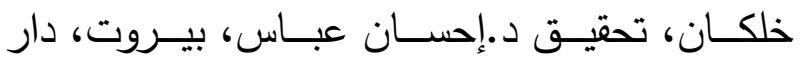

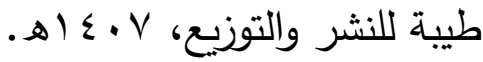

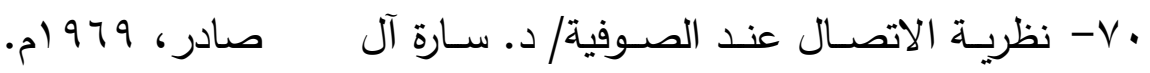




\title{
'Scholar's perspective of 'Al-Smaa
}

\section{Muhammad Ahmad Aljwair \\ Dar Al Uloom University}

\begin{abstract}
Sufism'. This behaviour is called 'hearing - Al-Smaa' and is familiar amongst them as a worship which brings one closer to Allah. This behaviour is linked with other actions such as dancing, stunting, slapping, tearing clothes etc ...

The current scholars hold the same opinion regarding this behaviour as the scholars from the past which condemned it to be an innovation in the religion. Furthermore they have responded to the innovators according to the right method of approach. Some imams, sheikhs, authors of Sufia and poets participates in these approaches .

What is remarkable that these responses and denials were in each era and epoch, this confirms the unity of the method in defending the faith and exposing the innovators' myths.
\end{abstract}

